\title{
VNĚJŠÍ OPEVNĚNÍ HRADU SKÁLY A DALŠÍ OBJEKTY V JEHO PŘEDPOLÍ
}

\section{LUDVÍK BELCREDI}

\begin{abstract}
Abstrakt: Archeologický výzkum vnějšich opevnění hradu Skály a dalšich objekti̊ v jeho okolí je jedním z prvnich svého druhu. Polygonální dřevohlinitá bašta, dělostřelecké pozice a predsunuté sruby střežicí prístupovou cestu jsou dokladem nového trendu opevněni hradi̊ doby husitské. Vápenka, dílny a kovářský areál doplňuji jeho výbavu a spolu s obléhacími pozicemi objasňuji jeho historii. Samostatným problémem je opevněné návrši nad hradem.
\end{abstract}

Klíčová slova: vnějši fortifikace hradu - husitské obdobi -dřevohlinitá bašta - výrobni objekty-dobývání hradu.

\section{The External Fortification of Skály Castle and Further Features in its Outer Ward}

Abstract: Archaeological research into the external fortification of the Skály castle and other features in its surroundings is among the first of its kind. A polygonal earth and timber bastion, artillery positions and forward log structures guarding the entrance route evidence a novel trend in castle fortification in the Hussite period. The castle amenities include a lime kiln, workshops and a smithy, and together with siege positions shed light on the castle's history. The fortified hill above the castle is discussed separately.

Key words: external castle fortification - Hussite period - earth and timber bastion - production features castle siege.

Hrad Skály se nachází na kopci Štarkov v katastru obce Nový Jimramov, nikoliv však na jeho vrcholku, jak by se dalo očekávat, ale asi $80 \mathrm{~m}$ pod ním. Tři strany jeho obvodu tvoří skály otevřené k severozápadu, odkud je uzavřen obvodovou zdí s bránou vysunutou do př́ikopu. Hrad je v polovině rozdělen téměř $3 \mathrm{~m}$ silnou zdí na vlastní jádro a předhradí, které vznikalo postupně. Stavba hradu probíhala $\mathrm{v} 70$. letech 14 . století a jeho zánik se datuje na počátek 40. let století následujícího, tedy do doby, kdy došlo $\mathrm{k}$ výrazné změně ve způsobu vedení války i obléhání opevněných staveb. Tím je dáno, že původní a závěrečná podoba jeho obranného systému se značně liší. Husitské a pohusitské období bylo dobou, kdy hrady procházely rozsáhlou a zásadní proměnou. Obrana nově budovaných hradů byla založena na zcela nových principech, které jim dali jejich stavitelé. Takoví dorazili i na hrad Skály a zanechali na něm své poselství v podobě nově vybudované předsunuté fortifikace, typické pro dřive založené hrady, které nebylo možné uvnitř novým trendům přizpůsobit. Mimo pasivní obrany, jako byly př́íkopy a valy, se však zde již u původní podoby hradu setkáváme se dvěma předsunutými věžemi kontrolujícími cesty kolem hradu a tím i cesty přístupové.

Pojednání o jádru hradu, stejně jako o jeho předhradí již bylo publikováno (Belcredi 2011; 2015). Obraz hradu dotváří prezentace penězokazecké dílny z doby po jeho dobytí (Belcredi 2012). Podobně jako v př́ípadě práce o jádru hradu a jeho předhradí není cílem ani této práce prezentace nálezů, nýbrž stavebních a dalších objektů v jeho předpolí a zprostředkování prvotního seznámení s výsledky výzkumu hradu širší odborné veřejnosti. Ve shodě s předešlými pracemi jsou také nálezy v jednotlivých objektech uvedeny pouze orientačně, a nikoliv v celém rozsahu, nebot' jejich uvedení v celé šíři by neúměrně rozšíŕilo tento článek. Ze stejného důvodu je uvedeno i omezené množství obrazové dokumentace. Přirozeně se počítá s podrobným publikováním výsledků, včetně studií a rekonstrukcí, které však nejsou součástí této prvotní informace.

Zatímco na stranách chráněných skalami se během celého vývoje hradu mnoho nezměnilo, z čela byl v průběhu 30. let 15 . století vybudován jedinečný komplex vnějšího opevnění. Skály skýtaly hradu přirozenou ochranu, ale vzhledem k jejich rozdílné konfiguraci byla každá strana chráněna jiným způsobem (obr. 1, pro lepší orientaci jsou světové strany popsány).

Na jihovýchodní straně padá prŕíkrý svah od hradby strmých skal téměř $400 \mathrm{~m}$ k ř́ičce Fryšávce a žádných obranných prvků zde nebylo třeba. Plasticitu terénu dodává podrobné zaměření 


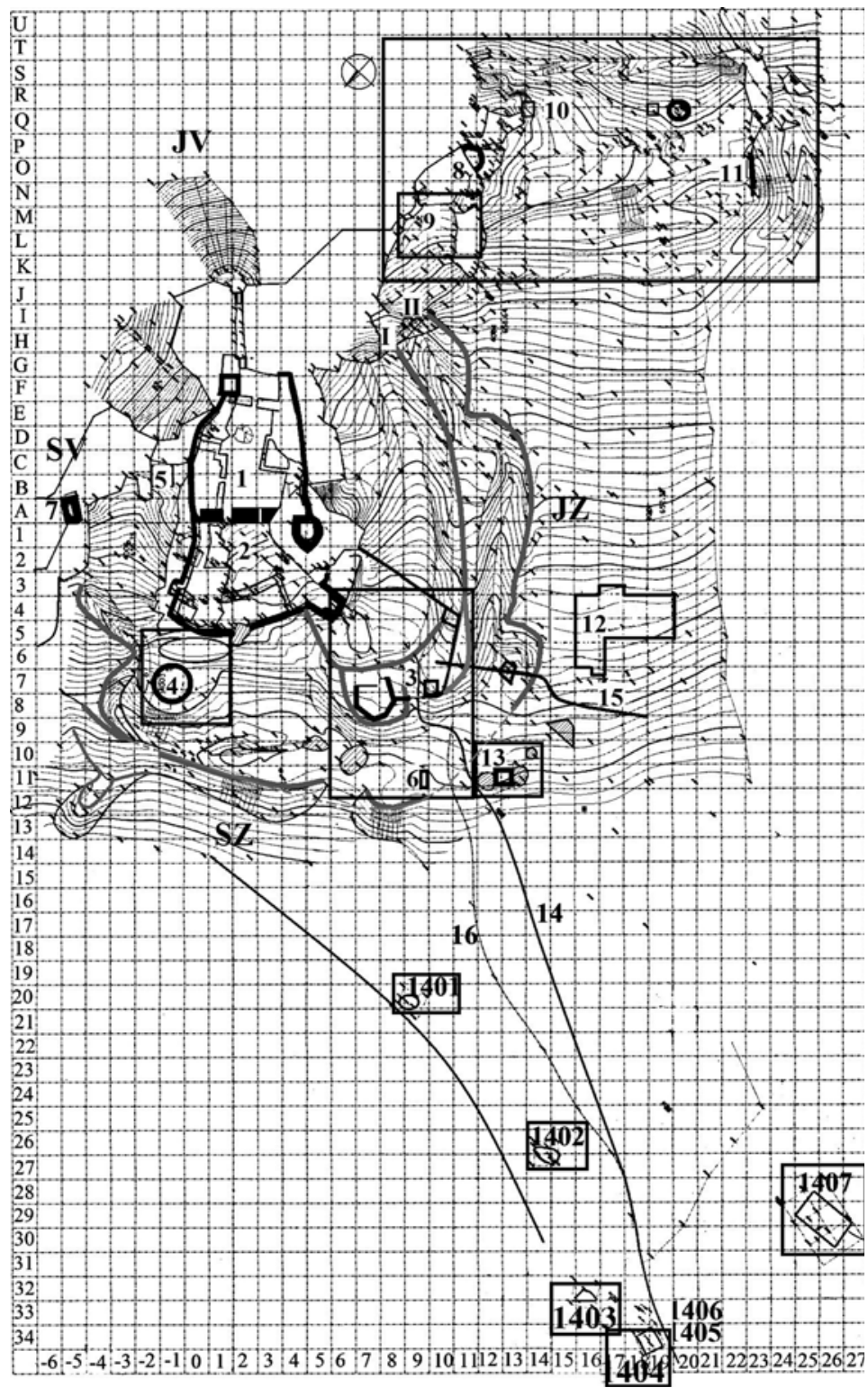

Obr. 1. Půdorysné zobrazení hradu Skály a objektů před ním. 1 - jádro hradu, 2 - druhé předhradí, 3 - první předhradí, 4 opevnění severního nároží, 5 - dílna na měděné výrobky, 6 - kovárna na barevné kovy, 7 - severovýchodní předsunutá věž, 8 - jižní předsunutá věž, 9 - vápenka, 10 - opevněné návrší, 11 - dřevohlinitá stěna, 12 - kovářský areál, 13 - předsunutý srub, 14 - př́stupová cesta do hradu, 15 - původní př́stupová cesta do hradu, 16 - dnešní cesta, 1401, 1402, 1404-1406 předsunuté zahloubené sruby, 1403, 1407 - obléhací postavení, I, II - valy. Šedě zvýrazněny průběhy valů: tenká čárková linie - zrušené úseky, silná linie - současný stav. Po obvodu vyznačení číslování čtvercủ v síti $5 \times 5 \mathrm{~m}$ a ve vyobrazení body výškového zaměření. Kresba Ing. D. Šiler.

Abb. 1. Grundrissdarstellung von Burg Skály und der vor ihr liegenden Objekte. 1 - Kernburg, 2 - zweite Vorburg, 3 - erste Vorburg, 4 - Befestigung der Nordecke, 5 - Werkstatt für Kupferprodukte, 6 - Buntmetallschmiede, 7 - vorgezogener Nordosturm, 8 - vorgezogener Südturm, 9 - Kalkofen, 10 - befestigte Anhöhe, 11 - Holz-Lehm-Wand, 12 - Schmiedeareal, 13 - vorgezogener Blockbau, 14 - Zugangsweg zur Burg, 15 - ursprünglicher Zugangsweg zur Burg, 16 - heutiger Weg, 1401, 1402, 1404-1406 - vorgezogene eingetiefte Blockbauten, 1403, 1407 - Belagerungsstellungen, I, II - Wälle. Grau hervorgehobener Verlauf der Wälle: dünne gestrichelte Linie - beseitigte Abschnitte, starke Linie - gegenwärtiger Zustand. Linker und unterer Rand - Nummerierung der Quadrate des 5 × 5 Meter-Rasters, in der Abbildung die Höhenvermessungspunkte. Zeichnung Ing. D. Šiler. 
vrstevnic, které spolu se čtvercovou sítí $5 \times 5$ m tvoří zásadní a neoddělitelnou součást grafické prezentace výzkumu. Skály se táhnou k jihu a na jejich konci, ve vzdálenosti $62 \mathrm{~m}$, je na nich umístěna půlkruhová věž (obr. 1:8), střežící vrchol kopce nad hradem i údolí pod ním. Pestrá členitost skal na jihovýchodě nevylučovala jejich využití obyvateli hradu, proto byla mezi nimi odkryta řada míst, avšak s negativním výsledkem. Jediným pozitivním zjištěním byla vanovitě vysekaná nádrž, do které ještě dnes omezeně stéká voda a která byla zjevně využívána jako zdroj čisté pitné vody. Z jejího středu vyrůstá staletý buk, který průzkum značně omezil. Mezi skalami sem z hradu ústí úzká, dvěma branami zabezpečená chodba, skrývající zadní východ z paláce. $Z$ nižších poloh není viditelná, takže neznalý netušil, že se zde nachází. Útok z této strany by byl nesmírně náročný a předem odsouzený $\mathrm{k}$ nezdaru.

Severovýchodní strana je chráněna hradbou skal táhnoucích se ve vzdálenosti 8 až $18 \mathrm{~m}$ od zdi hradu po celé jeho délce. Mezi ní a hradební zdí, postavenou na výrazně nižším skalním bloku, vznikl přirozený př́kop. V jeho nejvyšším bodě je k mohutnému skalnímu masivu přistavěna hranolová věž dosahující jeho vrcholku a skýtající daleký výhled (obr. 1:7).

Jihovýchodní svah stoupá mezi skály této strany ještě v délce $35 \mathrm{~m}$. Na vrcholu je přehrazen příčným skalním blokem, za nímž vznikl prostor ohrazený ze dvou stran svislými skalami. Uzavřenost tohoto místa obyvatelé využili k umístění dílny, jež vyráběla předměty z mědi (obr. 1:5). Její velikost byla $4 \times 4 \mathrm{~m}$. U skály na jihovýchodě se nacházela vrstva mazanice ze zničeného ohniště či malé výhně. Pod severovýchodní skálou ležely zbytky malty a do ní zapíchnutá šipka. Na téže straně je vstup do 3,5 m dlouhé jeskyňky trojúhelníkovitého průřezu o šířce $97 \mathrm{~cm}$ až $1,2 \mathrm{~m}$, překryté dvěma šikmými skalními deskami. Uvnitř nebyl učiněn žádný nález. Vzhledem $\mathrm{k}$ tomu, že sousedí přímo s pracovním prostorem, je velmi nepravděpodobné, že by nebyla nijak využívána. Směrem $\mathrm{k}$ hradu je dílna ohraničena jen nízkým skalním výstupkem v délce $2,3 \mathrm{~m}$. Nalezli jsme zde opravdovou hromadu měděných odstřižků různé velikosti a tvaru, ale i hraněnou petlici, pásek s mnoha otvory v podobě sítka, šipku s křidélky, bronzové slitky, mince, hrací žeton, velké množství silně strávených kostí rozsekaných na malé kousky a spoustu keramiky. Tyto nálezy hovoři jasně o tom, že se zde nejen pracovalo, ale i stravovalo. Nedaleko dílny ležely další bronzové slitky, šipky a kování. Nelze vyloučit, že dílna byla součástí padělatelských aktivit. Jasno do problému snad vnese až podrobné vyhodnocení všech nálezů. V hloubce $30 \mathrm{~cm}$ pod tvrdě udusanou podlahou se v celé ploše objevila černá vrstva s nálezy dlaždiček, kachlů, a to i prořezávaných a mincí, svědčící o požáru tohoto místa. Na severozápadě prostor vymezuje terénní zlom, od něhož svah táhle klesá k severu. Ve vzdálenosti 23 m, na úrovni čelní zdi hradu, ho protíná val severozápadní strany. Sonda položená svahem dolů odkryla místy řady kamenů položených snad za účelem zpevnění svahu proti erozi. Nalezli jsme v ní hřebíky a přezku.

Oproti dílně byla obvodová zed' hradu postavena jen na $2,5 \mathrm{~m}$ vysoké skále, vně šikmo stesané pod úhlem zhruba 45 stupňủ. Směrem k severozápadu se skála zvyšuje a stává se nepřístupnou. Zdivo je $\mathrm{v}$ jednom místě prolomeno brankou vedoucí na skalní blok zakončený prevétem pro předhradí. Není vyloučeno, že z něho bylo možné sestoupit do příkopu a výrazně si tak zkrátit cestu k věži. Zajímavostí je zjištění hluboké skalní průrvy táhnoucí se pod skálou od čtverce $2 /-1$ až do čtverce 3/-1, která je př́írodním výtvorem. Členitost skal této strany, jejich strmost a výška značně omezují př́ístup, takže napadení hradu ani odtud nepřicházelo v úvahu. Dostat se do tohoto prostoru bylo možné jen od severozápadu přes svah plný balvanů a střežený př́íkop. Znamenalo by to vstoupit na prudký svah kontrolovaný zprava z obvodové zdi hradu postavené na nepř́istupné skále a zleva z vysoké věže, i když u ní zřejmě funkce pozorovací převažovala nad obrannou.

Jiný př́iběh vypráví každá ze dvou zbývajících stran. Hrad vznikl v 70. letech 14 . století za Archleba ze Stařechovic, př́islušníka boční větve pánů z Kunštátu. První zpráva o hradu pochází z roku 1384, od té doby až do roku 1415 jej držel Archlebův syn Erhart ze Skal, za kterého byl hrad rozšířen a dostavěn (Belcredi 2015). Poté zde již sídlily jen lupičské družiny (Belcredi 2010). Nejdříve Erharta Pušky z Kunštátu a Otaslavic a po jeho smrti v roce 1419 zřejmě její prohusitsky orientované zbytky. Po bitvě u Lipan sem dorazila velmi početná skupina táboritů pod vedením hejtmana Jana z Břežan, která hrad držela až do jeho konce v roce 1440. Je logické 
předpokládat, že především z tohoto období pochází vybudování systému vnějšího opevnění. Objevili jsme však doklady i ze staršího období a některé terénní úpravy v předpolí je bezesporu možné přičíst i na konto oblehatelů.

Na jihozápadní straně plášt' hradu tvoří vysoké kolmé skály s vyzděnými mezerami a terén před nimi zvolna klesá od skal na jihovýchodu k severozápadu. Již od počátku byl před nimi zřízen dvojitý prríkop a val. Vnitřní př́ikop byl vytvořen stupňovitým odtesáváním skály po svahu dolů. Působí poměrně plytkým dojmem, ale vzhledem $\mathrm{k}$ jeho šířce bylo možné z vytěženého materiálu navršit značně vysoký vnitřní (první) val (obr. 1:I). Př́ikop je 20 až $28 \mathrm{~m}$ široký a k prvnímu valu stoupá strmě, místy na jeho hraně vystupují skály. Hliněný vrchol valu byl úzký a zpevněný kameny. Na vnější straně padá prudce do druhého př́íkopu, který je naopak ve tvaru písmena $\mathrm{V}$, o maximální šířce $8 \mathrm{~m}$. Oproti vnitřnímu příkopu je výrazně užší a hlubší. Vnější (druhý) val (obr. 1:II) přechází v terén jen lehkým obloučkem. Materiál z tohoto př́ikopu byl zřejmě použit na oba valy.

Historie se na těchto valech podepsala několika úpravami. Zásadní změnu jsme zjistili na vnitřním valu v místě jeho rozšíření ve čtverci 3/11 (obr. 2:556), proti brance pro pěší (Belcredi 2015). Zachoval se zde destruovaný kamenný základový věnec s množstvím mazanice a uhlíků. Velké černě zbarvené spáleniště zasahuje až do čtverce 3/10. Pochází zřejmě ze srubu zhruba o velikosti $3 \times 3 \mathrm{~m}$, který se stal obětí požáru. Jeho poloha v tomto místě ukazuje, že i ve starším období mohlo být předpolí hradu jistým způsobem chráněno. Od jeho poloviny dále k jihovýchodu totiž došlo k navýšení valu o 50 až $80 \mathrm{~cm}$ a jeho hřeben byl zpevněn velkými kameny zapuštěnými kolmo hluboko do jeho tělesa. Stejným způsobem byl val zpevněn i mezi dřevohlinitou baštou a obvodovou stěnou hradu. Jedná se o jinou technologii, než se kterou jsme se setkali u valů na kopci Čepička, kde byl jejich povrch po celém obvodu zpevněn věncem nasucho kladených kamenů (Belcredi 1990, 100).

Na jihovýchodní straně je prríkop ve čtverci G/6 ukončen skalami vytvořenou jeskyňkou. Ačkoliv se prostor k využití přímo nabízel, byl zcela bez nálezů. Je nutno říci, že výzkum všech jeskynních prostor v okolí hradu byl negativní. Ve čtverci $2 / 7$ se nachází prŕístup na skalní plato před brankou pro pěší. Před ním u skály byl terén srovnán jílem do roviny, avšak žádnou případně zpevněnou cestu k tomuto místu jsme nenalezli.

Př́íkopy a valy jihozápadní strany byly systematicky prozkoumány souběžnými sondami ve vzdálenostech $5 \mathrm{~m}$ od sebe. $Z$ vnitřního př́íkopu sondy byly vedeny přes první val do druhého prŕíkopu a pokračovaly až na druhý val. Přinesly doklady způsobu jejich budování vršením vykopané hlíny a zpevněním kameny. Od objektu 558 ve čtverci 4/11 (obr. 2) jsme do př́kopu a dále přes vrchol druhého valu až do čtverce 4/13 spustili sondu. Zjistili jsme, že vnitřní val je na vnější straně zpevněn velkými balvany a prudce klesá do druhého př́íkopu. Do něho napadalo množství velkých kamenů, které původně mohly být na vrcholku některého z valů. Dna př́íkopu jsme nedosáhli, nebot' po zahloubení se v něm objevila voda. Ta v těchto místech postupně vysychala a znovu se objevovala, jedná se tudíž o spodní vodu. Svah vnějšího valu je i dnes stále dosti strmý. $V$ př́íkopu byla nalezena poklička. Val dále prochází čtvercem $5 / 11$, v němž se již pod dvaceticentimetrovou vrstvou humusu objevilo jeho těleso a z něho vyčnívající kameny. Na pomezí čtverců 6 až 7/10 jeho vnitřní strana klesá do prostoru opevnění před bránou hradu, zatímco vnější pokračuje jako val až do čtverce $8 / 10$ (obr. 2).

Ve čtverci 6/9, oproti bráně do hradu, je kontreskarpa vyzděna nasucho kladenými kameny zpevňujícími nájezd na most. Je velmi pravděpodobné, že délka mostu spojujícího hradní bránu $\mathrm{s}$ vnitřním valem se přestavbami nezměnila, nebot' most směřoval na vystupující skálu na prvním valu (obr. 2:546), vzdálenou od brány $17,5 \mathrm{~m}$. Ta zřejmě hrála v jeho ukotvení významnou roli, nebot' nese stopy mnoha úprav a původní cesta směřovala po jejím jižním okraji k druhému príkopu.

Ve čtverci 5/12 je druhý př́íkop mělčí, ale prudce stoupá na vrchol vnějšího valu. V polovině čtverce se náhle rozšiřuje a vytváří široký oblouk, vzdálený od vrcholu vnitřního valu $15 \mathrm{~m}$. Zde se nacházel původní vjezd do hradu, který tuto vzdálenost překonával pomocí dalšího mostu, jehož piliř tvořil velký kámen či spíše kus skály o základně $3,8 \times 4,8 \mathrm{~m}$ a výšce 1,7 až 


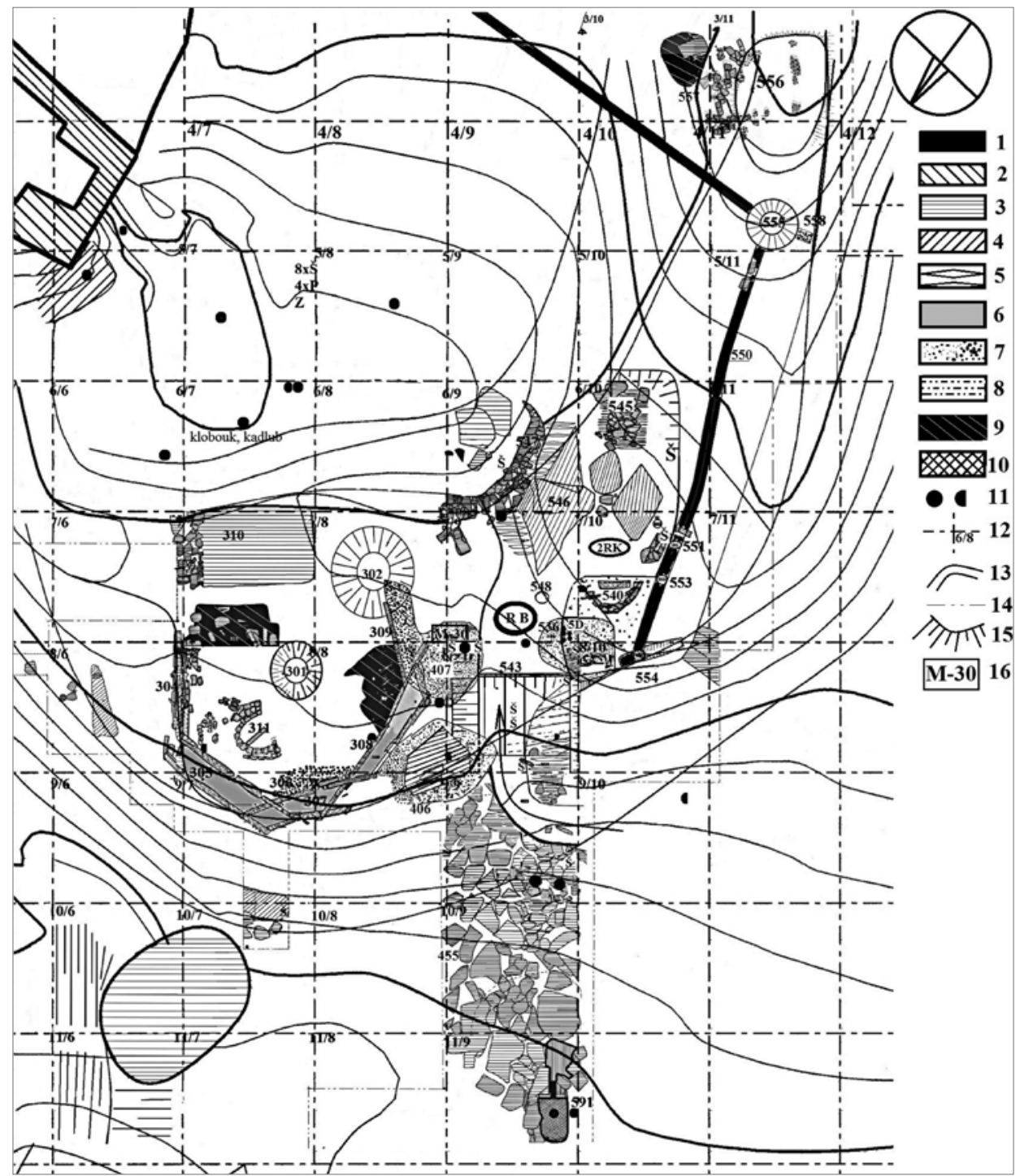

Obr. 2. Půdorysné zobrazení prvního předhradí s vyznačením objektů a některých nálezů. 1 - průběh dřevěné obvodové hradby, 2 - zdivo, 3 - dlažba a jednotlivé kameny, 4 - skála, 5 - štětování, 6 - hlinitopísčitá výplň stěn bašty, 7 - mazanice, hustota bodů dle jejího množství, 8 - dřevo, 9 - spáleniště, 10 - výheň a ohniště, 11 - dělové koule a jejich části, 12 - čtvercová pětimetrová sít', 13 - vrstevnice, 14 - výkopové hrany, 15 - sklon terénu, 16 - vyznačení mocnosti mazanicových vrstev $\mathrm{v}$ centimetrech.

Abb. 2. Grundrissdarstellung der ersten Vorburg mit Kennzeichnung der Objekte und einige Funde. 1 - Verlauf der Holz-Außenwand, 2 - Mauerwerk, 3 - Steinplattenboden und einzelne Steine, 4 - Felsen, 5 - Steinbett, 6 - Lehm-Sand-Verfüllung der Basteiwände, 7 - Lehmbewurf, Punktdichte entsprechend seiner Menge, 8 - Holz, 9 - Brandstätte, 10 - Esse und Feuerstelle, 11 - Kanonenkugeln und ihre Teile, 12 - Fünf-Meter-Raster, 13 - Höhenschichtlinie, 14 - Aushubkanten, 15 - Geländeneigung, 16 - Angabe der Stärke der Lehmbewurfsschichten in Zentimetern.

1,9 m, nacházející se ve středu tohoto př́ikopu (obr. 1, čtverec 7/13). Povrch kamene je zarovnán a v přibližně stejné niveletě jako úroveň druhého valu, kde leží značné množství kamenů, původně patrně tvořících podezdívku vjezdu na tento most. Přes něj se cesta dostávala mimo hradní areál do čtverce 7/14, esovitě se stáčela a pokračovala od čtverce $8 / 15$ až do čtverce $9 / 18$, kde 
mizí. Zůstala po ní menší mez, kterou je možné od hradu sledovat ještě několik desítek metrů. Oblouk druhého valu není uzavřen, nýbrž v místě, kde se stáčí k severu (o 12,5 m dále ve čtverci 8/13) splývá s terénem. Jeho pokračování bylo zjevně odstraněno při budování nové přístupové cesty po roce 1434 . V ústí druhého př́íkopu dnes leží nevýrazná vyvýšenina, o které ani nelze rríci, že by byla jeho provizorním uzavřením.

Severozápadní val před hradem vykazuje mnoho druhotných zásahů (obr. 1). Původně pravidelně a bez přerušení obkružoval severozápadní stranu hradu a navazoval na dnes ukončený vnější val, zatímco vnitřní se tyčil vysoko nad ním a zřejmě od počátku byl stočen ke zdi hradu. Takto situace vyhlížela po většinu doby existence hradu. K úpravám vnějšího valu zřejmě došlo až v závěrečném desetiletí jeho života.

Nevíme přesně, kdy se situace před hradem začala zásadním způsobem měnit. O příčinách nás informuje německý kronikář Hans Gysler, který dne 29. května roku 1438 píše, že 1. června toho roku dá Albrecht udeřiti na hrad Skály (genant Schal) na Moravě, kde je více než 500 táboritů, kteří odtud činí velké škody (Měřínský 1972, 237-241). To je zásadní informace, nebot' z archeologického výzkumu vyplývá, že během husitského období žila na Skalách jen nevelká komunita, které k životu stačilo pouze jádro hradu (Belcredi 2015). Albrecht v té době táhl ze Znojma do Prahy a ke hradu Skály nakonec nedorazil. Situace však musela být velmi vážná, když se jí zabýval i Albrechtův historik. Počet husitů s největší pravděpodobností nadsadil, ale zemní práce na hradě nemohla provádět malá skupinka lidí. Uvnitř hradu se nic zásadního nezměnilo, nebylo opraveno ani vyhořelé zdevastované předhradí, což svědčí o tom, že pro ně nebylo důležité (Belcredi 2015). Mnohem významnější byla situace před hradem, kde vyrostla řada nových opevnění, včetně mohutného opevnění před bránou hradu. Obyvatelé hradu se tedy k jeho obraně zjevně chystali po delší čas, a tak museli být přesvědčeni o své schopnosti ho ubránit. Zarážející je, že jsme nalezli stopy po rozsáhlých terénních pracích, ale nikoliv místo, kde by takové množství lidí mohlo přebývat. Vyvstává tak myšlenka, že to nebylo v bezprostřední blízkosti hradu, ale v jeho okolí. V úvahu přichází např́íklad protější kopec, dnes s malou osadou nazývající se Rabuňka, což vzbuzuje určitou asociaci. Bydlet mohli též v údolí pod hradem u ř́čky Fryšávky, kde je dnes osada Jimramovské Paseky.

\section{Budování vnější obrany hradu}

Jistě by bylo zajímavé znát ideu, na jejímž základě se zbytky polních vojsk vypravily právě k tomuto hradu a zvolily si ho za svou základnu. Neznáme rok, kdy sem dorazily, ale podle toho, že některé stavby se zdají být nedokončené, mohlo $\mathrm{k}$ jejich příchodu dojít až ke konci 30 . let 15. století, a nikoliv ihned po prohrané bitvě samé. Strůjcem tohoto nápadu musel být někdo, kdo na hradu již dříve pobýval, znal ho a věděl, že bude k dispozici. Politická situace v té době byla velmi komplikovaná a řada táborských hejtmanů si v ní opatřila nemalé majetky. Někteří se zařadili do probíhajících jednání, jiní však ani potom nepřestali s přepadáním a olupováním. Takový byl např́íklad Jan Kolda ze Žampachu, který držel poměrně velký majetek, ale ani ten mu nestačil ke krytí nákladů (Wolf 2002, 22). Nemáme zprávy o tom, že by si zdejší hejtman Jan z Břežan zaknihoval nějaké statky, zato se svou posádkou přepadal a loupil v širokém okolí, ale také opevňoval hrad Skály.

Po celou dobu vrcholného středověku byla základní obrannou linií hradu hradba zděná z kamene na maltu. Doplňovaly ji pasivní prvky obrany jako př́íkop, val, hrazené ochozy či rybník. V 15. století, za husitských válek, se situace změnila a základním prvkem fortifikací se stal násep (Sýkora 2013, 239). Na jedné straně se u hradu Skály setkáváme s navýšením valu, na druhé však s jeho odstraněním, aby nebránil ve výhledu a střelbě. Obrana hradu, původně založená na zónové ochraně vycházející z postřelování př́íkopů a valů kušemi z obvodové hradby a věží, tak byla zásadním způsobem změněna na základě nových zbraní, rozšiřrených během husitských válek. Palné zbraně byly u nás známy již v druhé polovině 14. století, ale husitské hnutí znamenalo jejich značné rozšíření. Masové použití palných zbraní mělo na dosavadní hradní produkci zcela zdrcující účinek (Sýkora 2013, 10). Proto vybavení hradů střelnými zbraněmi 
bylo přirozeným vývojem a nutností. Roku 1430 se v hradním inventáři Točníku objevuje soupis jeho vybavení palnými zbraněmi. Mimo jiné v něm bylo sedm větších děl (Vildštejnka, tarasnice, houfnice, steinbüchse) a 16 ručnic (Sýkora 2013, 160). Je jistě podnětná úvaha o tom, že děla na hradě neměla takový význam jako při jeho dobývání (Varhaník 2002, 136). Hrála však nezastupitelnou roli právě při ostřelování dělostřeleckých obléhacích postavení nacházejících se mimo dosah ručních palných zbraní, jejichž účinnost navíc byla v případě opevnění těchto postů minimální.

Tak jak si to doba vyžadovala, podstatou nového systému obrany i na hradě Skály se stalo využití palných zbraní. Obraně hradu palnými zbraněmi zatím nebyla věnována větší pozornost, zvláště jako součásti předsunutého opevnění (Plaček-Měřínský 1992, 276-295; Plaček 2002, 139-54; 2007; Durdík 1999; 2003, 16; Varhaník 2002, 125-138; 2003, 32-33; Gabriel 2006, 8-13; Šimůnek 2010, 185-219). Badatelé se téměř výlučně soustřed'ují na části hradů s kamennou architekturou. Na vnější zemní fortifikace prakticky rezignovali a ty tak dosud zůstávají neznámé, a pokud se jimi někdo zabývá, v důsledku naprostého nedostatku terénních výzkumů o nich hovoří spíše na bázi teoretické, vycházející z terénní prospekce. Zemním fortifikacím a jejich vztahu k okolnímu terénu se s různou intenzitou věnovali T. Durdík a M. Plaček (Durdík 1991, 151-164; 1992, 321-335; 1996, 35-46; 1999, 21-24; 2011, 114-115; 2011a, 12-16; Plaček 2002, 139-154; Kypta-Richterová 2002, 54-56). Nejvíce prostoru této problematice dosud věnoval M. Sýkora (2013). Bohužel ani on neměl jinou možnost než své interpretace o průběhu a podobě vnějších nezděných opevnění založit především na terénní prospekci, i když s využitím moderních metod, především mapování. A tak podobně jako jiní autoři své hmotové studie obdařil systémem různorodých palisád, plotů, hradeb, srubů a bašt. Jak ukázal výzkum předpolí hradu Skály, je skutečnost od těchto představ hodně vzdálena. Také zde před výzkumem panovala domněnka, že po celém obvodu valů probíhala hradba nebo alespoň nějaké oplocení, na jeho rozšiřrených plochách měly stát věže či alespoň sruby atd. Všechny tyto představy šly stranou a potvrdilo se, že archeologický výzkum je jedinou možností, jak zjistit skutečnou podobu těchto opevnění. Na základě poznatků z tohoto výzkumu můžeme říci, že skutečnost se od dosavadních studií, popisů a závěrů o podobě nezděných předsunutých opevnění výrazně liší.

Vnější opevnění hradu Skály vycházelo z obecně platného poznání, že umístění děl do areálu staršího hradu není možné a je třeba uplatnit maximální obranné prvky v jeho předpolí. V tomto př́ipadě se jeho obrana zaměřila na dva opěrné body, situované na nárožích čelní obvodové stěny. Zatímco severní nároží bylo opatřeno jen na povrchu srovnaným kruhovým opevněním chráněným příkopem (obr. 1:4), na rozšířeném valu před hradní bránou vyrostl opevněný areál velikosti $22 \times 25 \mathrm{~m}$ (obr. 1:3). Jeho podstatnou část tvořil vnitřní př́ikop, v němž se před hradní bránou stále držela voda. Přístupová cesta byla přeložena a nová brána ústila na val na severozápadní straně hradby (obr. 2:543). Od severovýchodu ji střežila mohutná dřevohlinitá bašta zabírající plochu $10 \times 12,5 \mathrm{~m}$, o které můžeme říci, že je naprosto unikátním a ojedinělým dokladem dochované fortifikace hradu. Druhou stranu vjezdu střežilo dělostřelecké postavení, situované proti př́ijezdové komunikaci (obr. 2). Nájezd na most do brány hradu byl přesunut na opačnou stranu vystupující skály na prvním valu a kolem něho byla vytvořena plošina $12 \times 7 \mathrm{~m}$. Stejně jako původní př́ijezd i nový ležel vůči bráně mírně excentricky. V místě, kudy přes první val procházela původní cesta, byl navršen štěrkopískový val, vně precizně obložen kameny. Od jeho vrcholku byl terén vysvahován do značně zahloubeného př́íkopu, obsahujícího množství nálezů. V žádném jiném místě jich v příkopu nebylo nalezeno takové množství. Od jihozápadu areál v délce $17 \mathrm{~m}$ vymezovala zahloubená linie po dřevěné obvodové hradbě vedené po vnitřní straně valu až do čtverce 4/11, kde byla ukotvena do velké jámy (objekt 558). Od ní linie směřovala pod tupým úhlem v délce $25 \mathrm{~m}$ prres příkop ke skále u branky pro pěší. Prostor před bránou tak byl velmi dobře opevněn a zajišt'oval bezpečný nástup na most do hradního areálu. Základem nově budované fortifikace se stala dřevohlinitá bašta. Opevnění ze dřeva na valech a další v předsunutém postavení, nasucho kladené zídky a podezdívky nalezneme např́íklad na Levnově - Ketkovickém hradě (Plaček 2007, 347-348). Na hradě Panně spočívaly dřevěné konstrukce různých podob na korunách nasucho obezděných teras, náspech a podezdívkách (Sýkora 


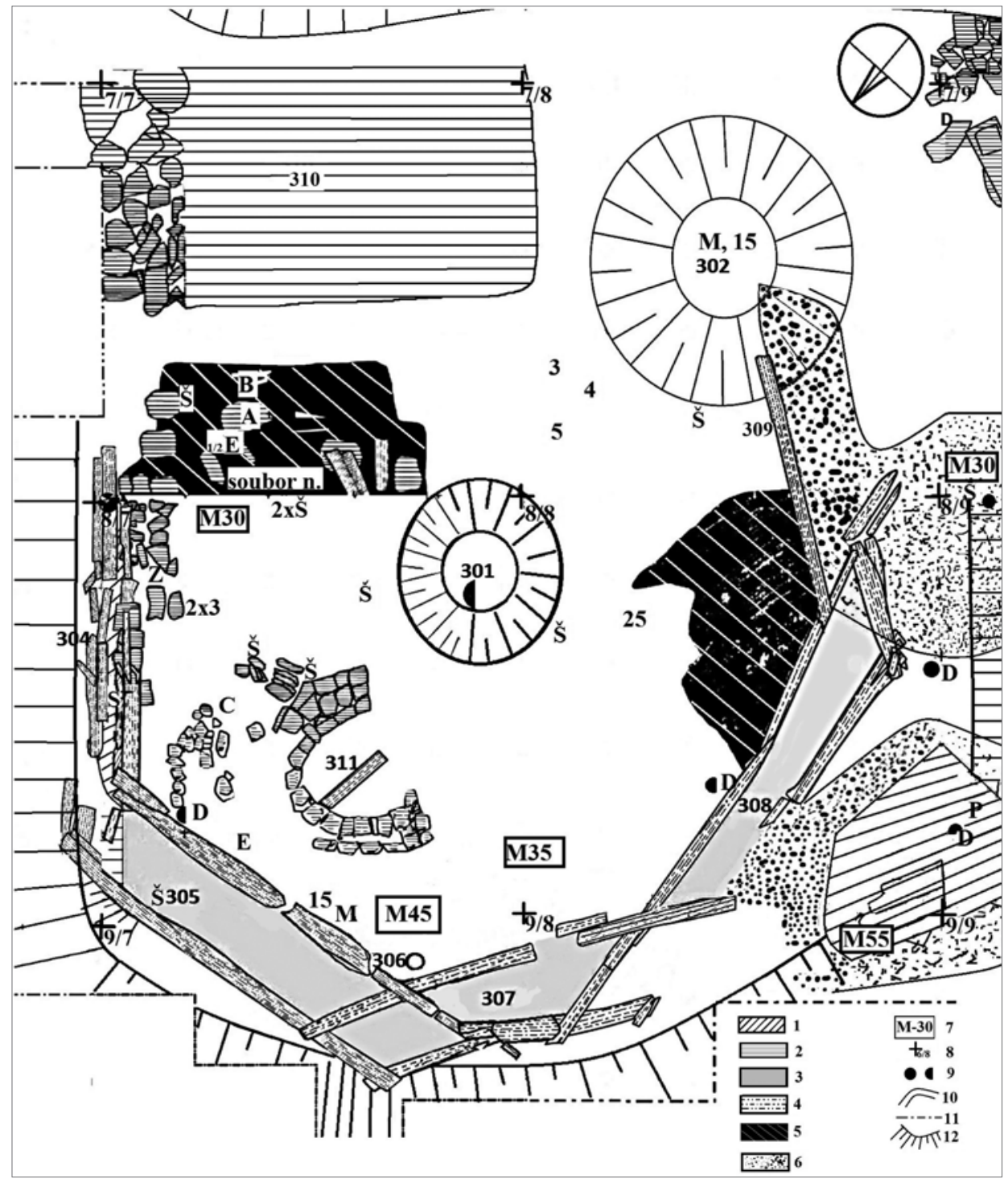

Obr. 3. Půdorysné zobrazení dř̌evohlinité bašty s vyznačením objektů a některých nálezů. 1 - skála, 2 - dlažba a jednotlivé kameny, 3 - hlinitopísčitá výplň stěn bašty, 4 - dřevo, 5 - spáleniště, 6 - mazanice, hustota bodů dle jejího množství, 7 vyznačení mocnosti mazanicových vrstev v centimetrech, 8 - body čtvercové pětimetrové sítě, 9 - dělové koule a jejich části, 10 - vrstevnice, 11 - výkopové hrany, 12 - sklon terénu. Nálezy: A - hrnec, B - pohár, C - kahánek, D - dělové koule a jejich části, E - poklice, $M$ - mince, $P$ - podkova, Š - šipka s tulejí, Z - visací zámek, 3 - nủž, 4 - sekáček, 5 - knoflík, 15 - kroužková zbroj, 25 - velký hřeb. Soubor zahrnuje kování dveří, závorovou skobu, západku zámku, dva závěsy dveří a postranici. Objekty: 301, 302 - kruhové jámy, 304, 305, 307, 308 - stěny bašty, 306 - kủlová jamka.

Abb. 3. Grundrissdarstellung der Holz-Lehm-Bastei mit Kennzeichnung der Objekte und einiger Fundstellen. 1 - Felsen, 2 - Steinplattenboden und einzelne Steine, 3 - Lehm-Sand-Verfüllung der Basteiwände, 4 - Holz, 5 - Brandstätte, 6 Lehmbewurf, Punktdichte entsprechend seiner Menge, 7 - Angabe der Stärke der Lehmbewurfsschichten in Zentimetern, 8 - Punkte des Fünf-Meter-Rasters, 9 - Kanonenkugeln und ihre Teile, 10 - Höhenschichtlinien, 11 - Aushubkanten, 12 Geländeneigung. Funde: A - Topf, B - Becher, C - Öllämpchen, D - Kanonenkugeln und ihre Teile, E - Deckel, M- Münzen, P - Hufeisen, $\check{S}$ - Pfeil mit Tülle, Z - Hängeschloss, 3 - Messer, 4 - Hackmesser, 5 - Knopf, 15 -Ringpanzer, 25 - großer Nagel. Der Komplex enthält Türbeschläge, einen Riegelhaken, eine Schlossraste, zwei Türangeln und ein Seitenteil. Objekte: 301, 302 - Kreisgruben, 304, 305, 307, 308 - Basteiwände, 306 - Pfahlgrube. 
2013, 53). Dřevěné stavby tedy nebyly považovány za ústup ze stavební slávy a opuštění zděných technik, ale za něco, co v kombinaci dřeva, hlíny a popřípadě i kamene lépe odolávalo novým formám boje.

\section{Srub - bašta}

Srub je typickou stavbou husitského období. Setkáváme se s ním od samotných počátků tohoto hnutí, otázkou však je, v jaké podobě. Vavřinec z Březové píše, že při bitvě na Vítkově 14. července 1420 postavili dva sruby na způsob jizeb a propojili je mělkým prríkopem, který obehnali zdí z hlíny a kamení. Zajímavá je zmínka, že obránci neměli šípy ani prach do houfnic a museli se bránit sudlicemi, což vypadá, jako by jim šípy a prach došel (Vavřinec z Březové 1979, 82-83, 89-90). Informace o tom, jak tyto sruby vypadaly, nemáme, rozhodně však nemohly být podobny opravdové jizbě se střechou, protože tak by je nemohli obránci bránit sudlicemi. Nejspíše se tedy jednalo o čtyřstranné sruby bez střechy, v jejichž dolní části mohly být i stř́lny. Jeden takový zobrazil grafik Burgmaier st. (Sýkora 2013, obr. 165). Také další zmínka o srubu je od téhož autora a vztahuje se k počátkům hradu Kalicha. Nás zajímající verze říká, že Žižka na jedné vysoké hoře „postavil nějakou ohradu ze srubư“, což naplňuje naši představu o srubu bez střechy. Druhá verze je pro nás nezajímavá (Sýkora 2013, 22).

Podoba obranné stavby na Skalách je však zcela odlišná. Nejedná se totiž o srub, ale o polygonální šestistrannou dřevohlinitou baštu. Nacházela se $20 \mathrm{~m}$ před bránou do hradu na výrazném půlkruhovém sypaném náspu. Jeho severovýchodní a severozápadní strana se prudce svažovaly a jihozápadní navazovala na bránu (obr. 2 a 4). Na povrchu se před výzkumem rýsovaly dvě výrazné zahloubeniny. Pro jejich velikost bylo možné se domnívat, že se jedná o zahloubené sruby chránící př́ístup k bráně, a od místních jsem dokonce slyšel, že se jedná o bunkry partyzánů z druhé světové války. Skutečnost byla zcela odlišná. Převážnou část této plochy pokrývala

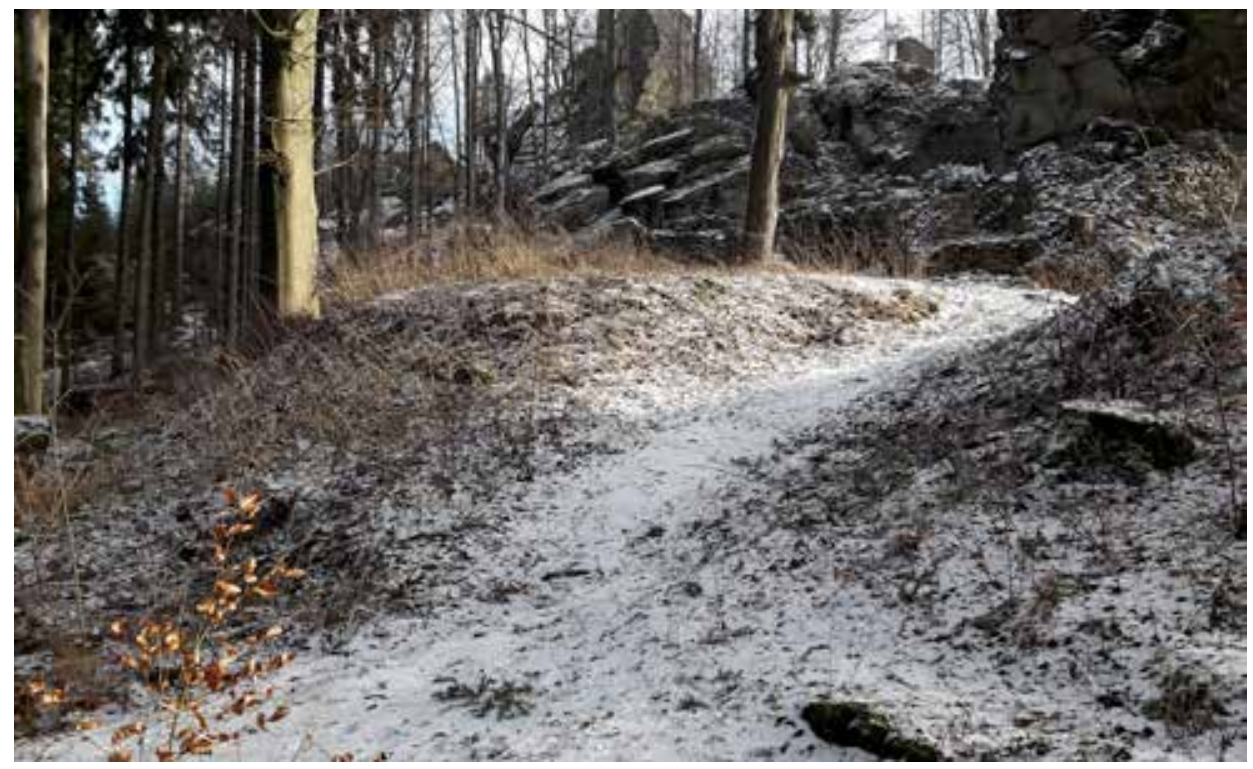

Obr. 4. Pohled od obléhacího postavení (obr. 1:13) na bránu prvního předhradí a sypaný val, na kterém stála polygonální dřevohlinitá bašta.

Abb. 4. Blick von der Belagerungsstellung (Abb. 1:13) auf das Tor der ersten Vorburg und aufgeschütteter Wall, auf dem die polygonale Holz-Lehm-Bastei stand. 
mocná vrstva silně propálené mazanice. Její povrch byl tak hladký, že jsme se zprvu domnívali, že se jedná o výmaz rozsáhlého ohniště. Situace se začala měnit s jejím odstraňováním. Ukázalo se, že se jedná o $30 \mathrm{~cm}$ mocný mazanicový masiv vypálený silným žárem do rudé barvy, který tvořil strop stavebního objektu. Spočíval na černé spálené vrstvě obsahující množství více či méně zuhelnatělých dřev, ležících původně ve směru jihovýchod-severozápad, některé již byly ze směru vybočeny. O silném žáru vypovídaly přepálené kameny zbarvené až dofialova. Rozsáhlé spáleniště obsahovalo též velké množství nálezů - tři nože, sekáček, visací zámek, ostruhu, podkovu, přezku, šipky, poklici, celý kahánek atd.

Na rozhraní čtverců 8/6-7, prŕimo na hraně svahu, jsme narazili na dobře dochované trámy, ležící podélně přes sebe ve směru jihovýchod-severozápad (obr. 3:304). Mezi dvěma z nich byla natlačena vrstvička žlutého jílu o síle 2 až $3 \mathrm{~cm}$. Mazanice zde dosahovala ke hraně severovýchodního svahu a na ní spočívala řada kamenů s množstvím uhlíků. Na vnější straně se pod nimi opět objevila mazanice, což svědčilo o převrstvení a posunutí této stěny až na samotnou hranu terasy, místy až za ni. Ve velkém rozptylu zde byly roztříštěny kousky dělové koule. Na severozápadním konci se trámy zahlubovaly a od západu je křižovaly dvě řady trámů severní stěny, se kterými byly provázány (obr. 6). Pak již šlo jen o to, držet se dochovaných trámů jdoucích po okrajích koruny tohoto hliněného náspu. Takto bylo možné vysledovat i další strany a následně zjistit, že se jedná o nesmírně zajímavou šestistrannou dřevohlinitou baštu. Severovýchodní strana se nakonec ukázala jako nejvíce poškozená, zřejmě proto, že jako jediná byla založena klasickým způsobem na kamenech uložených na povrchu terénu.

U dalších stran jsme zjistili, že stěny bašty tvořily dvě souběžné řady trámů vzdálené od sebe 50 až $60 \mathrm{~cm}$, mezi něž byla nabíjena žlutá zemina s pískem. Strany jsme očíslovali od severovýchodu čísly 304 až 309. Číslo 306 je kruhový zahloubený objekt na místě vnitřního křížení stěn 305 a 307. Na jižní straně stěny 305 byla vrstva rudě vypálené mazanice nejmocnější. Dosahovala tloušt'ky až $45 \mathrm{~cm}$, nebot' byla vtlačena do snížené podlahy. Byla ukončena ostrou linií žluté barvy, kterou se projevovaly vrstvy mezi trámy. Ve střední části této stěny se nacházel nejzachovalejší trám o průměru $24 \mathrm{~cm}$ a nalezli jsme zde i půlku dělové koule zaraženou mezi kameny. Prošla žárem, který ji zbarvil červeně. U některých stěn se dochovalo i více trámů, na severozápadní straně byly zachovány tř̌i trámy, v místě čelního kř́ižení dokonce čtyři nad sebou (obr. 5). To záviselo na hloubce založení jednotlivých stěn pod povrchem (obr. 7:1 a 8:D-D'). Jelikož terén stoupal od stř̌edu jihozápadním směrem, snižoval se tím i počet zachovaných trámů ve stěně. Kř́ížení trámů stěn 305 a 307 na severozápadní straně bylo umístěno na střed bašty a vybíhalo $1 \mathrm{~m}$ do čtverce 9/7 (obr. 7:1,2). Fixaci tohoto kř́ižení mohl napomáhat $15 \mathrm{~cm}$ silný kůl zapuštěný do kůlové jamky, ukazující, že původní kř́žžení se nacházelo více jihovýchodním směrem a celá konstrukce sjela k severozápadu. Kůl však mohl pocházet i z doby rozměřování bašty a ukazovat, kde má dojít ke křŕžení klád. Stěna 307 byla výrazně kratší než ostatní. Také z ní se zachovaly dvě řady trámů, mezi něž byl nasypán hlinitopísčitý materiál (obr. 7:1, 3). Za kř́žením se stěnou 208 se na vnitřní straně dochoval pouze jeden trám na úrovni podlahy, na vnější, která byla ve svahu založena o $75 \mathrm{~cm}$ níže, se zachovaly nad sebou dva ohořelé trámy o průměru $20 \mathrm{~cm}$. Jeden byl ve středu prolomen a do zásypu mezi stěny se z vnější strany dostaly kameny a mazanice. Možná že prolomení způsobila dělová koule nalezená nedaleko. Leželo zde větší množství přepálených plochých kamenů.

Do východního rohu čtverce $9 / 8$ bylo umístěno křížení stěn 307 a 308. Zatímco vnitřní strana stěny 308 byla zachována v celé délce, $\mathrm{z}$ vnější se dochovala pouze její jižní část a nepatrný úlomek nad koncem vnější stěny 307. Prostor mezi trámy byl opět vyplněn žlutým jílem a pískem. Její trámy byly sice zčernalé ohněm, ale místy zachované ve značném průměru. Vnitřní strana trámů byla jakoby omazána mocnou vrstvou vypálené mazanice, nacházející se i v jejím okolí (obr. 7:1 a 8:E-E'). Zde byla nalezena polovina, u vnějšího křižení stěn 308 a 309 celá dělová koule, ale i dlaždičky o rozměrech $10 \times 10 \mathrm{~cm}$, velký hrnec s uchem a množství další keramiky. U křížení stěn na vnitřní straně leželo ve spáleništi opět větší množství plochých kamenů do velikosti $20 \mathrm{~cm}$. 


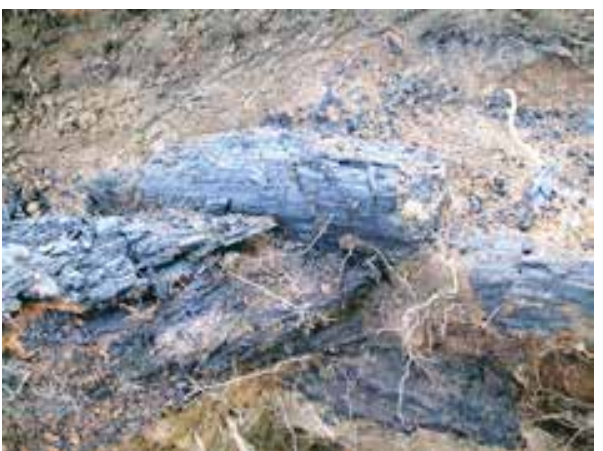

Obr. 5. Křižení trámů vnějších stěn 305 a 307 dřevohlinité bašty.

Abb. 5. Verschränkung der Außenwandbalken 305 und 307 der Holz-Lehm-Bastei.

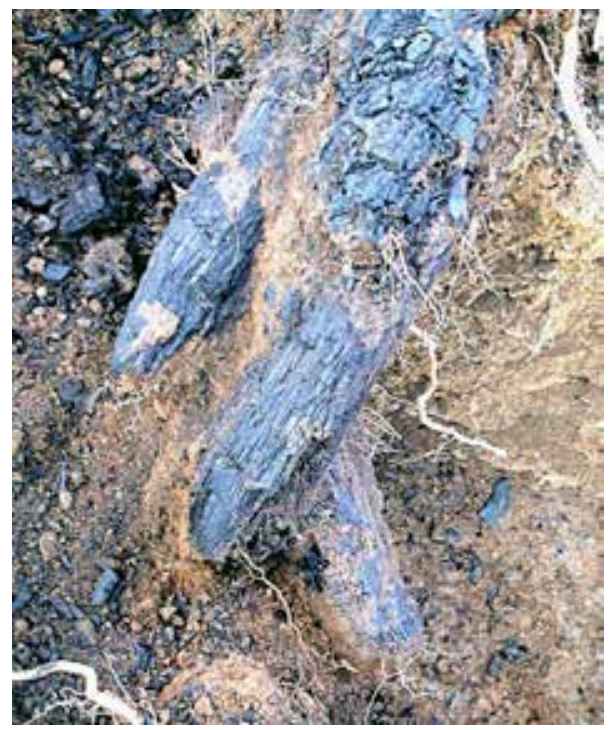

Obr. 6. Křížení trámů vnitřních stěn 304 a 305 dřevohlinité bašty.

Abb. 6. Verschränkung der Außenwandbalken 304 und 305 der Holz-Lehm-Bastei.

čení její druhé strany není jasné. Ukotvení do objektu 301 by bylo velmi problematické a dále $\mathrm{k}$ jihozápadu stěnu nedokládá zhola nic. O jejím průběhu, a př́ípadném vyvázání na objekt 302 , můžeme pouze spekulovat.

Vzhledem k tomu, že objekt 301 se nachází v nejširším místě stavby a na její ose, by bylo logické, kdyby podpíral př́ičný trám, jehož délka zde musela dosahovat $9 \mathrm{~m}$. Na něm spočívala třiceticentimetrová vrstva mazanice stropního výmazu o značné váze, tvořící zároveň pultovou střechu. Tu dokládá rovná vyhlazená mazanicová vrstva s předpokládaným sklonem k jihovýchodu. Dláždění (objekt 310; obr. 3:310) naznačuje, že střecha mohla být dotažena až k němu a voda po něm mohla stékat do prŕíkopu. Stěna by tu nemusela být, pokud by pultová střecha dosedala až k zemi, ale to je nepravděpodobné, nebot' $\mathrm{v}$ tom př́ípadě by zde nebyly nálezy dokládající přítomnost dveř́í.
Vnitřní stěna 309 byla zachována v délce 3,3 m od vnitřního kř́ížení se stranou 308 , vnější jen v úseku mezi trámy strany 308 a její zbytky byly vykloněny vně. V pokračování jejího směru se objevila mocná vrstva propálené mazanice. Trámy nedosahovaly $\mathrm{k}$ velké zahloubené kruhové jámě, objektu 302. Ten se nacházel ještě o $70 \mathrm{~cm}$ dále. Jeho průměr na povrchu byl $3 \mathrm{~m}$, ale rychle se zužoval na $1,2 \mathrm{~m}$, odkud byly jeho stěny svislé do hloubky 1,4 m. Obsahoval nálezy kroužkové zbroje, hřebíků i minci. Jelikož stěna 309 nebyla na severovýchodní straně vyvázána na žádnou jinou, bylo její ukotvení v objektu 302 zřejmě zásadním.

Jen $2,5 \mathrm{~m}$ severním směrem od ní se na ose stavby v úrovni kř́ížení stran 308 a 309 nacházel obdobný kruhový zahloubený objekt 301 . V něm se po odstranění $20 \mathrm{~cm}$ zeminy ukázala vrstva mazanice $\mathrm{s}$ úlomkem dělové koule. Jáma měla stržené hrany, takže její šířka u povrchu dosahovala $2 \mathrm{~m}$, avšak rychle se zužovala na $1,2 \mathrm{~m}$ a dosáhla stejné hloubky. V prostoru mezi ukončením trámů severovýchodní stěny a vnějším okrajem objektu 301 se na podlaze v délce $3,2 \mathrm{~m}$ rýsovalo velmi výrazné barevné rozhraní. Oddělovalo podlahu bašty od velkého spáleniště se změtí zuhelnatělých dřev a opálených kamenů, $v$ němž byly nalezeny dvě závěsné skoby, závorová skoba, kování zámku, západka zámku, také postranice a tři šipky s tulejkou. Mezi kameny se nacházela též keramika, především krásný pohár. Zvláště důležitou roli mezi nálezy hrají předměty dokládající existenci dveří a přímá barevná linie vzniklá patrně vyvrácením celé stěny, což je velmi důležité zjištění, nebot' jinak jsme na této straně uzavření objektu nenalezli. Že zde musela být nosná zed', ukazuje i uložení stropních trámů. Na jedné straně mohla být fixována do stěny 304 , avšak ukon- 


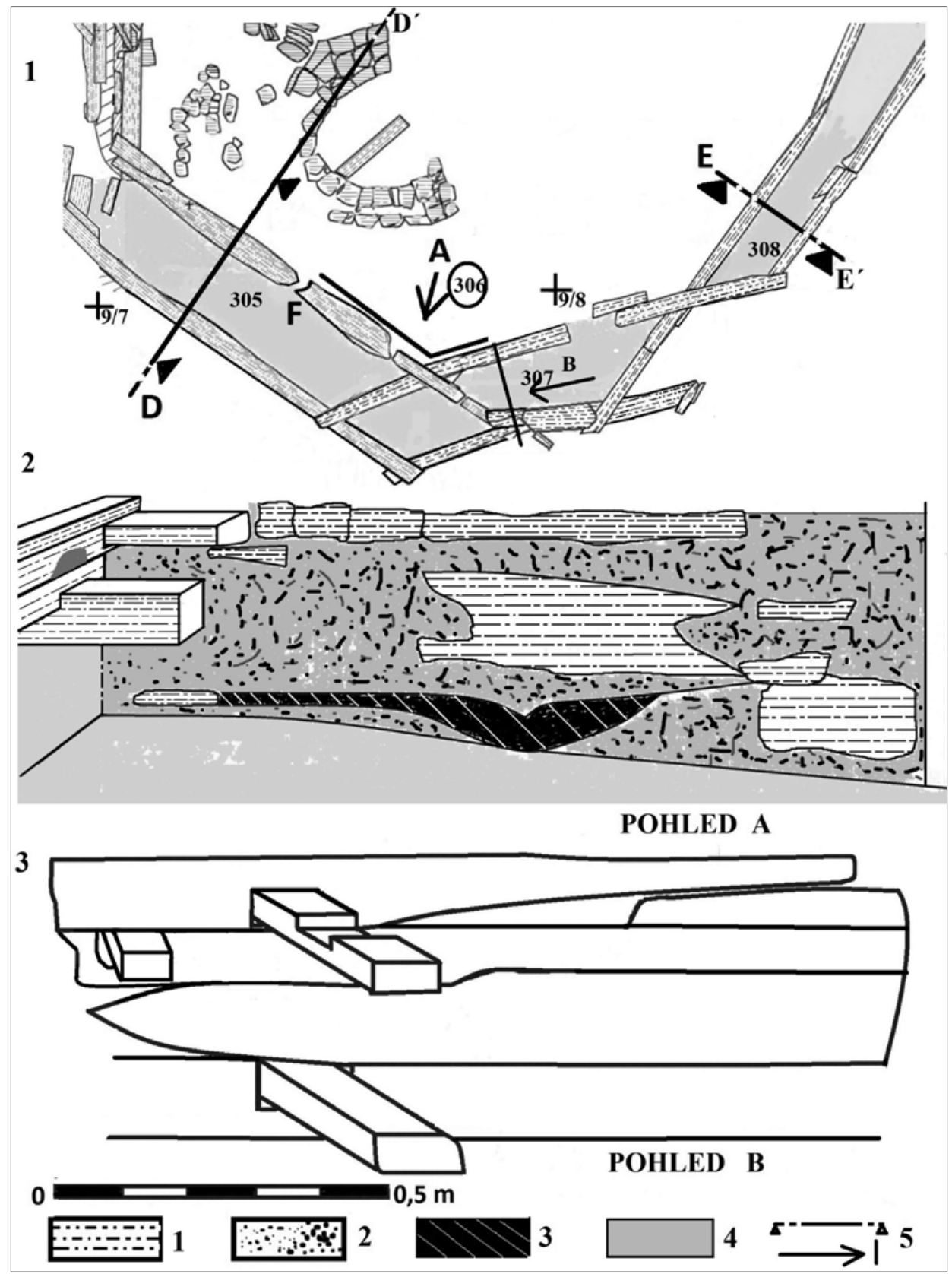

Obr. 7. Vyznačení profilů stěnami a pohledy na kř́žení stěn dřevohlinité bašty. 1 - trámy, 2 - mazanice, 3 - spáleniště, 4 hlinitopísčitá výplň stěn bašty, 5 - profily a pohledy. Pohled A na vnitřní křrižení stěn 305 a 307 zevnitř, pohled B na vnitřní křížení stěn 307 a 308 z boku.

Abb. 7. Kennzeichnung der Wandprofile und Ansichten der Verschränkung der Wände der Holz-Lehm-Bastei. 1 - Balken, 2 - Lehmbewurf, 3 - Brandstätte, 4 - Lehm-Sand-Verfüllung der Basteiwände, 5 - Profile und Ansichten. Ansicht A der inneren Verschränkung der Wände 305 und 307 von innen, Ansicht B der inneren Verschränkung der Wände 307 und 308 von der Seite. 
Ve vzdálenosti $1 \mathrm{~m}$ od stěny 305 bylo navršeno množství kamenů postavených na hranu, avizujících zřícenou klenbu (obr. 3:311 a obr. 9). Kameny ležely v několika vrstvách nad sebou. Po podrobném výzkumu se ukázalo, že se jedná o nesmírně zajímavé otopné zařízení, pícku podkovovitého tvaru ústím směřující k jihu s nevýrazně vypáleným výmazem. Její velikost byla $1,2 \times 1,2 \mathrm{~m}$ a nejlépe zachovanou se ukázala být severovýchodní strana se třemi až čtyřmi vrstvami kamenů na sobě, dosahující výše $30 \mathrm{~cm}$ a síly stěny $50 \mathrm{~cm}$. Největší vypálení se soustřed’ovalo do poměrně malého prostoru na severozápadní straně. Pícka byla založena na deseticentimetrové vrstvě žlutého jílu s hladce vymazaným povrchem. Pod ním se táhla tenká černá spálená vrstva o mocnosti $1 \mathrm{~cm}$, zřejmě starší podlaha, na které byla pícka založena.

Vnitřní prostor bašty měl největší šířku $8 \mathrm{~m}$ a délku $5,6 \mathrm{~m}$. Podlaha byla zpevněna jílem a vysypaná pískem. Zdá se, že stěna 304 byla zachována $\mathrm{v}$ celé své délce, je protažena za spojnici stěn 308 a 309, jejíhož konce nedosahovala. Je otázkou, proč je stěna 309 takto dlouhá, když byla umístěna na vnitřní straně podél brány. Na opačné straně by takové prodloužení bylo pochopitelnější. Bašta musela být stavěna podle předem promyšleného plánu, i když každá její strana byla jinak dlouhá. Nejdelší byla vnitřní strana stěny 308 , která dosahovala $7 \mathrm{~m}$, a stěna 309 , jejíž vnější délka byla 5,6 a vnitřní $5,9 \mathrm{~m}$. Nejkratší byla $\mathrm{z}$ důvodu větší stability bašty vnější strana stěny 307 obrácená k prŕístupové cestě, jejíž délka byla pouhých $3,4 \mathrm{~m}$. Tak mezi křižením stěn 305 a 308 zbývalo jen asi $50 \mathrm{~cm}$ na malé, ale o to důležitější okénko či stř́ínu. U jeho vnitřní strany však téměř $2 \mathrm{~m}$ zaručovaly $\mathrm{k}$ němu dostatečně pohodlný př́stup. Délka zbylých stěn se vně pohybovala v rozmezí 4,4 až 5,4 $\mathrm{m}$ a uvnitř od 5,3 do 5,6 $\mathrm{m}$. Strany 305 a 307 tvořily základ obrany bašty, což dokládá podlaha snížená uvnitř podél těchto stěn o $30 \mathrm{~cm}$, zjevně pro větší komfort střelců. $Z$ toho lze odvodit patrně nízký strop bašty, snad 1,5 m, u stěn tedy $1,8 \mathrm{~m}$. Výška čelních stěn, založených o $70 \mathrm{~cm}$ po svahu níže, pak musela být až $250 \mathrm{~cm}$. Ze střílny ve stěně 305 bylo možné kontrolovat téměř celý severní svah. Pokud by byly stř́ilny i v dalších stěnách, pak by z okna stěny 308 byl výhled přímo před bránu, a z opačné strany mohl být postřelován příkop včetně severního nároží, které jinak bylo ze strany hradu v naprostém střeleckém stínu.

Na stavbu musely být použity opravdu statné stromy, jestliže i po shoření byla síla některých trámů až $25 \mathrm{~cm}$. Pokud budeme v průměru počítat s tak silnými trámy, dojdeme k závěru, že jich na jednu stěnu muselo být použito sedm až deset, na zadní, méně exponované, byly použity jistě trámy slabší. Celkově lze počítat, že na baštu, mimo tyčkoviny na strop, bylo třeba skácet asi 50 stromů. Další byly třeba na obvodovou palisádu, stavbu u brány a předsunuté sruby. Počty skácených stromů tak jistě šly do stovek.

Unikátní obranná bašta na hradě Skály byla vybudována technikou dvou souběžných trámových stěn vzdálených od sebe $50 \mathrm{~cm}$. Trámy stěn byly vedeny tak, že vždy dosahovaly až k vnějším trámům sousedních stěn. Každý trám byl tedy fixován ve čtyřech bodech trámy sousedních stěn (obr. 3, 5-6). Ty byly do sebe nejen různými způsoby roubeny (obr. 8:1-3), ale jištěny i hřeby, jak ukazují jejich početné nálezy. Na vnitřních stranách delších stěn jsme se setkali s napojováním trámů, a to tím způsobem, že konec jednoho byl zahrocen, ve druhém byl vyseknut otvor stejného tvaru a byly do sebe zastrčeny a zajištěny hřebem (obr. 8:4). Mezi trámové stěny byla udusána hlinitopísčitá zemina. Místy byly stěny zřejmě obsypány hlínou a obloženy kameny. Základové trámy vnitřních stěn ležely prakticky na podlaze, zatímco vnější byly založeny až o $70 \mathrm{~cm}$ po svahu níže. Předpokládal bych jejich podložení kameny, aby nesjižděly po svahu, ale to jsme nezjistili. Hlína z vnější strany byla jistě přihrnuta co nejvýše. Po zrrícení bašty překryla zbytky trámů, díky čemuž se místy dochovaly ve více vrstvách. K jejich zachování by však určitě nedošlo, nebýt ohromné masy stropního výmazu, která se při požáru zrrítila a překryla celou plochu bašty. Zakonzervovala tak na téměř 600 let vše, co se v ní v daném okamžiku nacházelo. Důmyslná stavba představovala stabilní dřevohlinitou baštu odolávající po určitý čas i dělovým projektilům.

Bohužel trámy byly natolik ohořelé, že nebylo možné u žádného z nich provést dendrochronologické datování. Jejich rozbor ukázal, že ke stavbě stěn 305 a 307, tedy nejohroženějších, bylo použito jedlových klád, zatímco u ostatních, méně exponovaných, klád smrkových i modřínových. Přitom ve vlastním hradě bylo jako stavebního dřeva použito téměř výhradně jedle. 


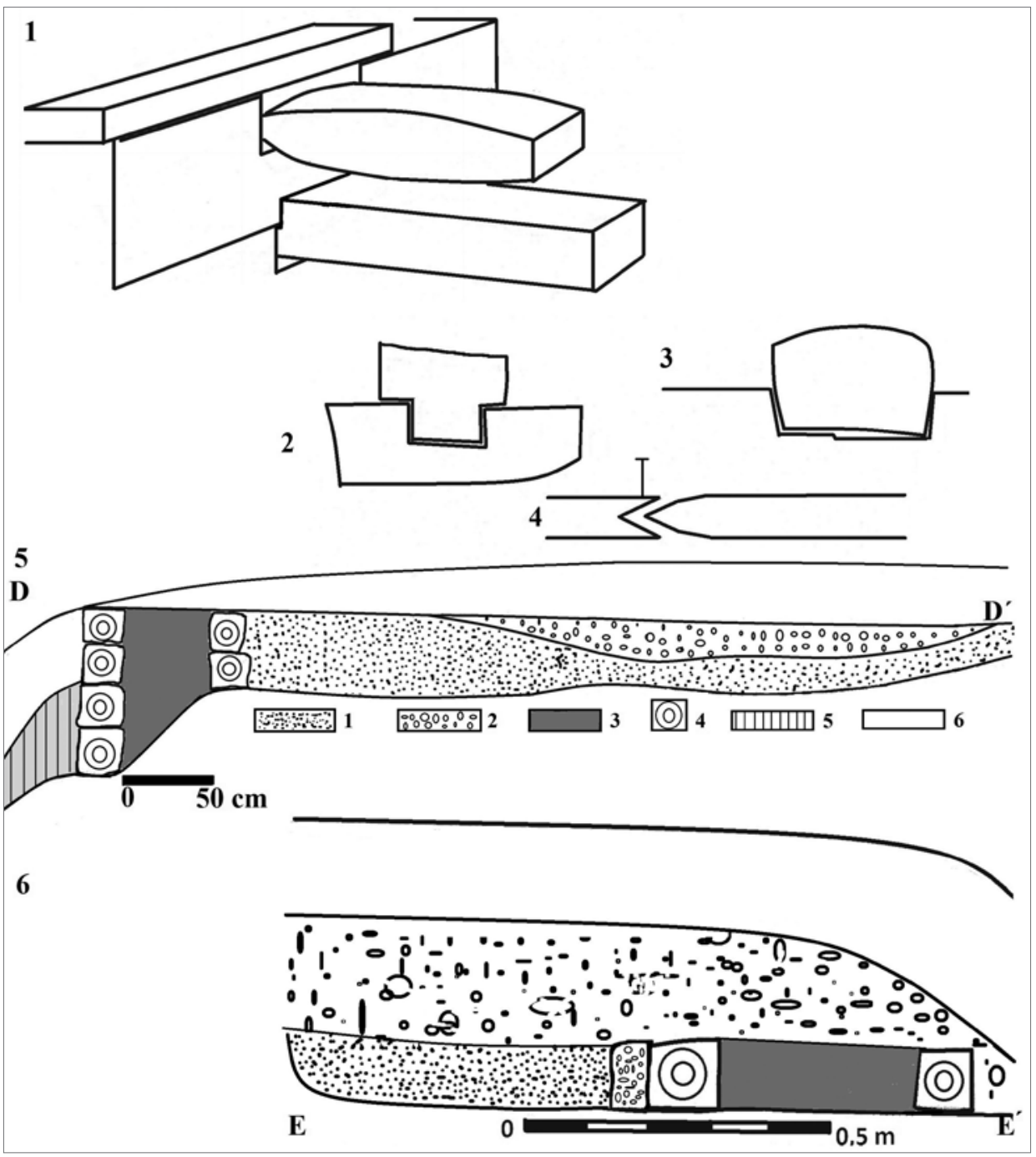

Obr. 8. 1-3 - způsoby roubení trámů stěn dřevohlinité bašty, 4 - způsob napojení trámů stěn dřevohlinité bašty, 5 - D-D'profil stěny 305, 6 - E-E' - profil stěny 308 (viz obr. 7:1), 1 - uhlíkaté vrstvy, 2 - mazanice, 3 - hlinitopísčitá výplň stěn bašty, 4 - trámy v řezu, 5 - jílová vrstva, 6 - hliněná vrstva.

Abb. 8. 1-3 - Zimmermannsmäßige Holzverbindungsarten der Wandbalken der Holz-Lehm-Bastei, 4 - Anschlussart der Wandbalken der Holz-Lehm-Bastei, 5 - D-D'- Wandprofil 305, 6 - E-E' - Wandprofil 308 (siehe Abb. 7:1), 1 - holzkohlehaltige Schichten, 2 - Lehmbewurf, 3 - Lehm-Sand-Verfüllung der Basteiwände, 4 - Balken im Profil, 5 - Tonschicht, 6 - Lehmschicht.

Použití smrku a modřínu může ukazovat na nedostatek jedlí v okolí hradu v době budování bašty. Zjištění existence modřínu je velmi př́ínosné, nebot' panuje názor, že v té době v této krajině vůbec nerostl. Použití různých druhů dřevin mohl způsobit fakt, že kmeny bylo nutné dovážet z větší vzdálenosti, nebot' stromy kolem hradu byly jistě použity při jeho stavbě. Za necelých 60 let, která od té doby uplynula, nemohly v jeho okolí stromy o takovém průměru vyrůst. Množství dřeva bylo navíc jistě spotřebováno v průběhu let i na topení. 


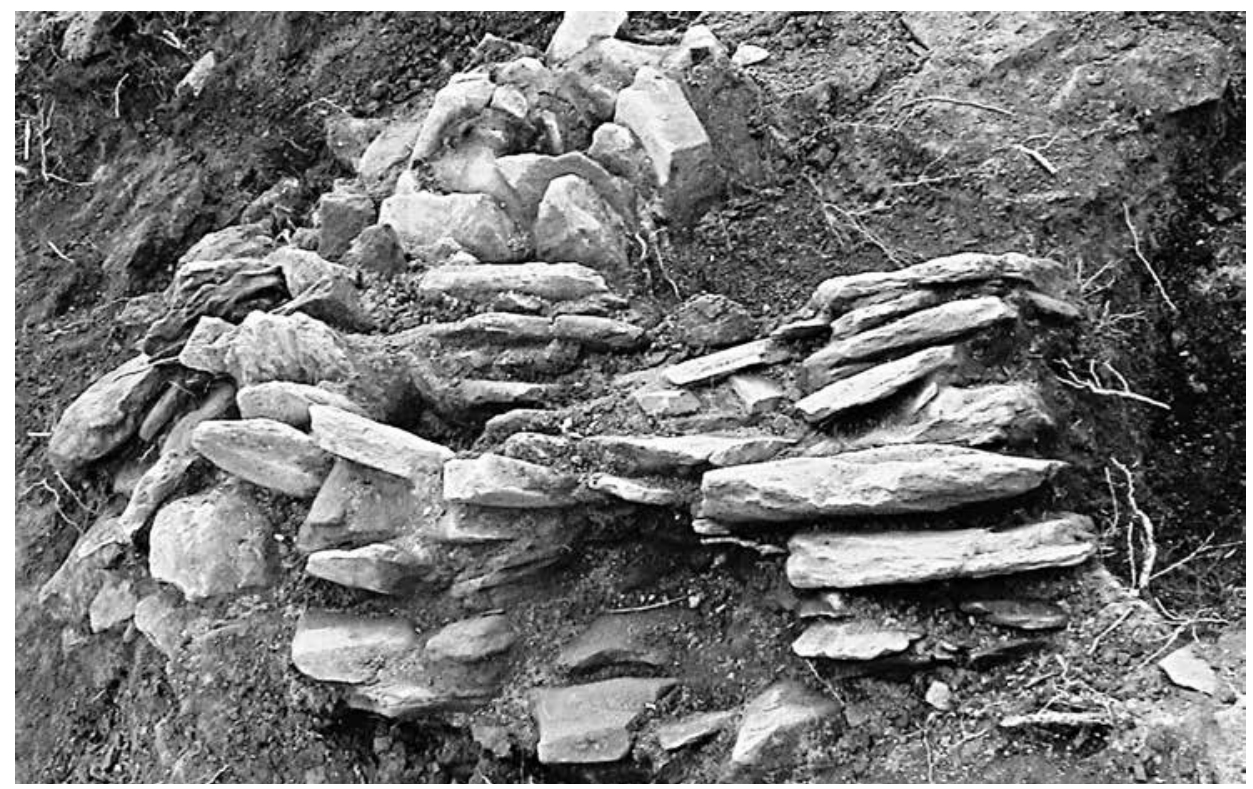

Obr. 9. Zř́ícená klenba pícky v dřevohlinité baště (obr. 3:311).

Abb. 9. Eingestürztes Gewölbe des Ofens in der Holz-Lehm-Bastei (Abb. 3:311).

Bašta hrála v obraně hradu zásadní roli, nebot' její stř́lny kontrolovaly prakticky celé předpolí. O jejím významu vypovídá i stav, v jakém jsme ji nalezli, nebot' byla rozstřílena a zapálena. Její dobytí znamenalo pro obránce fatální a nenahraditelnou ztrátu. Svým polygonálním tvarem předběhla dobu, nebot' jinak se s podobnými baštami setkáváme až později, avšak ve zděné podobě a bývají osazeny děly. Tato však děly být osazena nemohla. Při velikosti vnitřního prostoru a předpokládané výšce zastropení by bylo nezbytně nutné, aby z ní při výstřelu vyčnívala hlaveň děla ven, jinak by v ní nebylo možné kvůli kouři zůstat. Tuto skutečnost jsem měl možnost si ověřit u historické skupiny Buhurt, disponující replikou středověkého děla. Při síle mezitrámové výplně $50 \mathrm{~cm}$ a trámů 20 až $25 \mathrm{~cm}$ měla bašta stěny silné $1 \mathrm{~m}$. Takto potřebné délky většina houfnic, ba ani tarasnic nedosahovala, a pokud ano, byl by u nich problém s pevným ložem, obvykle sahajícím až k ústí hlavně. Pro tento prostor nejlépe vyhovuje použití pušky na podstavci, kterou bylo možné předem i zamířit do určitého místa (Wagner-Drobná-Durdík 1956, tabulka 12:VII). Pokud tedy hlaveň nemohla být vysunuta, pak prostor musel být dokonale odvětrán, což jeho uzavření v našem př́ípadě neumožňovalo. Navíc střílny, které znamenaly přerušení trámu, byly v zájmu zachování co největší stability bašty jistě co nejmenší, snad jen na výšku jednoho trámu, což též vylučuje užití děla.

Na svazích kolem bašty ulpělo množství mazanice, z níž část byla vypálena jen redukčně. Směrem po svahu dolů jí přibývalo a zasahuje $1 \mathrm{~m}$ do čtverce $9 / 8$. Zjevně sjela ze čtverce $8 / 8$. Silně propálená vrstva mazanice o mocnosti $55 \mathrm{~cm}$ ležela též na západ od bašty na stupňovitě klesající skále před bránou. Pod ní jsme nalezli velmi dobře zachovalé udidlo, tzv. sněhuláka, na uzdění těžkých koní.

Od předpokládané vnitřní stěny bašty je okraj valu směrem $\mathrm{k}$ hradu vzdálen $5 \mathrm{~m}$ a v ploše $2,8 \times 3,5 \mathrm{~m}$ vydlážděn (obr. 3:310). Hrana svahu je zpevněna kameny a prudce se svažuje do př́ikopu. Zbylá část valu odtud až k obvodové zdi hradu obsahuje značné množství velkých kamenů, vyčnívajících na povrch. 
Vstupní díl vnějšího opevnění - první předhradí (obr. 1:3 a obr. 2)

Před bránou do hradu Skály vzniklo opevnění, jehož terminologické zařazení je malým problémem. Opisem je možné říci, že se jedná o vstupní díl vnějšího opevnění, které můžeme nazvat prvním předhradím (dále tedy jen první předhradí). Za konzultaci děkuji M. Plačkovi.

Jedním z důvodů vzniku vnějšího opevnění byla potřeba zařadit do obrany hradu moderní palné zbraně a vysunout obranu co nejdále od něj. Dalším byla snaha přeložit př́ístupovou cestu tak, aby co možná nejdelší její úsek bylo možné kontrolovat. To původní cesta blížící se k hradu téměř po vrstevnici nesplňovala a obrana prakticky začínala až na úrovni druhého valu (obr. 1:15). Nová cesta byla pod kontrolou předsunutých srubů téměř od okamžiku, kdy opustila údolí Fryšávky, a hradu od vstupu na svah před ním (obr. 1:14). Ve vzdálenosti $25 \mathrm{~m}$ od brány prvního předhradí míjela předsunutý srub a před bránou tvořila esovité stočení. Po celé délce byla lemována velkými balvany, které bránily v odbočení z ní a frontálnímu útoku na bránu.

Brána byla situována jen $2 \mathrm{~m}$ od jihozápadní stěny bašty (obr. 2:543 a obr. 4) a tuto mezeru vyplňovala až $50 \mathrm{~cm}$ mocná vrstva vypálené mazanice s většími kousky uhlíků a dřev, zřejmě pozůstatek po dřevěné bariéře silně omazané hlínou. Obdobná vrstva o velikosti $3 \times 2 \mathrm{~m}$ se nacházela i na opačné straně brány a obsahovala množství nálezů. Mimo keramiky, 3/4 dělové koule, záštitu meče, zlomky podkovy, visací zámek, nože, a dokonce i stř́íbrný prsten.

Mezi mazanicovými krami zůstala téměř $3 \mathrm{~m}$ široká mezera po bráně. Cesta $\mathrm{k}$ jejímu prahu stoupala poslední $3 \mathrm{~m}$ poměrně prudkým svahem. Její jihozápadní strana byla zpevněna kameny a drtí, zbytek tvořil nezpevněný hliněný pás o šířce 1,4 až $1,6 \mathrm{~m}$. Po prahu brány se zachovala linie zčernalého dřeva ukazující na rámovou konstrukci. Pro tu svědčí i okolnost, že na okrajích nebyly zjištěny kůlové jamky. Na cestě a v bráně byly nalezeny šipky, velký zákolník, dělové koule, měděný pásek, keramika, kosti a úlomek okenní vitráže, což je pro tuto lokalitu ojedinělý nález. Při obvyklé šiřce cest do $1,6 \mathrm{~m}$ je šířka brány překvapující, ale snad vycházela z filosofie o potřebě větší propustnosti v prrípadě hromadného výjezdu vyššího počtu jezdců. Nejspíše však vedle brány byla branka pro pěší. Mezi vrstvou mazanice u brány a počátkem obvodové hradby zůstala ve valu $1,3 \mathrm{~m}$ široká mezera, v níž rovná plocha nádvoří pokračovala až na hranu svahu do prŕíkopu. Svah byl fixován vrstvou jílu, jeho dolní část až po nároží byla zpevněna kameny a ulpěla na něm vrstva mazanice o tloušt'ce $15 \mathrm{~cm}$ ze sousední mohutné kry. Místo bylo během bitvy dosti exponované, nebot' z jeho okolí pocházejí čtyři dělové koule a olověné projektily.

Na rovné ploše, v západním rohu čtverce $7 / 9$, jsme v prostoru $1 \times 1 \mathrm{~m}$ nalezli vedle sebe pět kamenných koulí. Svým zpracováním se lišily od dosud nalezených koulí oblehatelů. Jejich povrch byl totiž velmi nerovný, a tudíž byly ke střelbě z děla nepoužitelné, snad do praku. Vzhledem k jejich uložení se jedná o nevyužitý arzenál obránců hradu. Jen 1,4 m od nich směrem k jihu se nacházela částečně destruovaná podkovovitá pícka (obr. 2:540), zcela shodná s píckou v baště. Její vnější rozměr byl $1 \times 1,4 \mathrm{~m}$. Ve chvíli, kdy jsme obě pícky porovnali, vyvstalo před námi jejich použití. Jejich výmazy nemusely být př́lišs vypáleny, nebot' se jednalo o pícky sloužící k udržování pouze malého ohně či spíše možná jen žhavého troudu nutného k rozžhavení odpalovacího želízka či jiného předmětu, použitelného k zapálení střelného prachu palné zbraně. To, spolu s úpravou terénu, nás vedlo $\mathrm{k}$ domněnce, že se v mezeře ve valu nacházelo palebné postavení děla vybavené dřevěnou sklopnou stř́ilnou. $\mathrm{O}$ tom svědčí i hromada kamenů, které mohly sloužit $\mathrm{k}$ zatížení děla. Čtvrtinu čtverce $7 / 10 \mathrm{~s}$ přesahem do čtverce $8 / 10$ zabírala rovná plocha 3,5 × $3 \mathrm{~m}$ vyplněná velmi jemným žlutým až téměř bílým jílem, opět doprovázená množstvím nálezů. Pod jeho severozápadní částí se nacházela i zmíněná pícka. Zřejmě se tedy jednalo o nevypálený stropní výmaz, který končí u kůlové jamky (obr. 2:553), jež byla součástí ohrazení, a zastřešení do ní mohlo být ukotveno. Zdá se, že se tu nacházel jednoduchý přístřešek na kủlech, otevřený do stran. Proto se stropní výmaz zřítil, aniž by došlo k jeho vypálení.

Komunikace uvnitř areálu stoupala od brány ještě $80 \mathrm{~cm}$ vzhůru, pak se stáčela vpravo k vystupující skále a podél ní mířila šikmo na most do brány hradu. Př́ímá vzdálenost těchto bodů je 7,5 m, esovité stočení ji však o něco prodloužilo. Cesta byla široká $1,6 \mathrm{~m}$, na povrchu zpevněná drobnými kaménky. Jihozápadní strana nájezdu na most byla fixována mocnou 


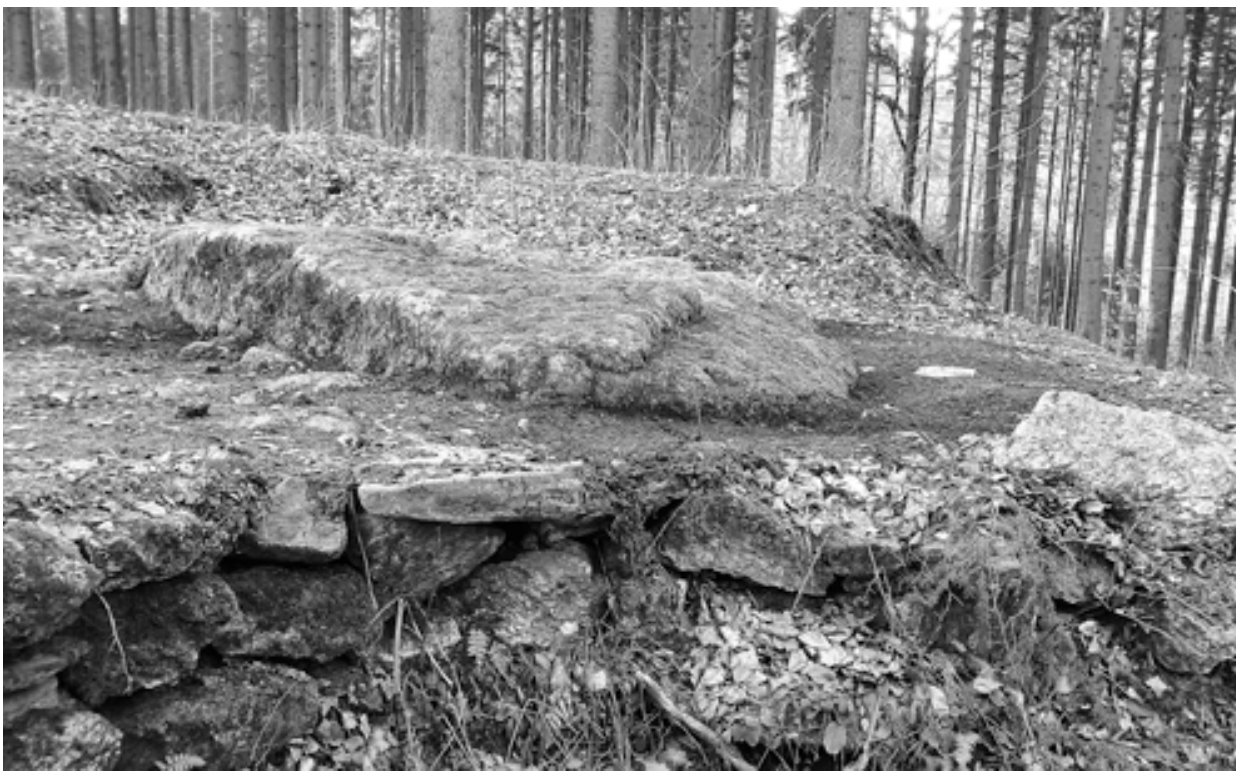

Obr. 10. Skála vystupující z prvního valu, k níž byl ukotven most do brány hradu. Pohled z př́íkopu od jihovýchodu. Vpředu nasucho kladená zed’ zpevňující nájezd, v pozadí val a místo brány.

Abb. 10. Aus dem ersten Wall hervortretender Fels, an dem die Brücke zum Burgtor verankert war. Blick vom Graben aus Südosten. Im Vordergrund die Auffahrt befestigende, trocken aufgeschichtete Mauer, im Hintergrund Wall und Stelle des Tors.

vrstvou jílu, dosahujícího až k obvodové palisádě. Jako ve starší době i nyní hrála v ukotvení mostu významnou roli vystupující skála o rozměrech $2,3 \times 3,4 \mathrm{~m}$. Nese stopy opracování do linií podle utváření nájezdů i pro uchycení mostu (obr. 10). Na cestě ležela roztř́ššěná dělová koule z bombardy (obr. 2:RB), jejíž úlomky o velikosti $20 \mathrm{~cm}$ dolétly až do vzdálenosti $8 \mathrm{~m}$, dále polovina malé koule, roztříštěné kousky dvou dalších (obr. 2:2RK) a také šipky, tedy bohatý vojenský arzenál.

Za vystupující skálou u nájezdu na most, v nejjižnějším výběžku ohrazení, se nacházela rovná dlážděná plocha $2 \times 1,75 \mathrm{~m}$, kterou bylo možné využít např́íklad k odstavení vozu (obr. 2:545). Tou nádvoří končilo a terén se za ní ostře zvedal na val. Další odstavnou plochu mohlo představovat dláždění (objekt 310) za baštou.

V místě nájezdu na most byla kontreskarpa podezděna až do úrovně povrchu cesty několika vrstvami nasucho kladených kamenů. Takto vytvořený taras o šířce $2 \mathrm{~m}$ a výšce $80 \mathrm{~cm}$ kopíroval obloukovité zakřivení valu v délce $3,7 \mathrm{~m}$ (obr. 2 a 10). Délka zpevnění byla tedy mnohem větší, než vyžadovala potřeba nájezdu. Taras byl nejvyšší v místě nájezdu a po stranách se snižoval. Poměrně prudce se terén od něho svažuje do př́íkopu. Jeho dno je v tomto prostoru zpevněno jílem, pod tarasem až $30 \mathrm{~cm}$ mocným, nebot' podpíralo jeho střední část. V několika vrstvách byl jíl položen i kolem velkých kamenů ve čtverci 6/9 nacházejících se v př́ikopu pod nájezdem na most, které s ním mohly souviset (obr. 2). V př́íkopu bylo nalezeno množství kovových předmětů, mimo jiné $29 \mathrm{~cm}$ dlouhý masivní hrot, a kamenný kadlub velikosti 17,4 × $11 \mathrm{~cm}$ na odlévání koule o průměru $6,3 \mathrm{~cm}$. Vedle něj ležela kamenná koule malé ráže a unikátní nález, zbytky železného klobouku, bohužel vážně poničeného. Pod jílovou vrstvou výmazu se nacházela černá vrstva původní úrovně příkopu, pokračující dále do jeho středu. Obsahovala opět řadu nálezů, především desítky podkov, plát kování a značné množství hřebů, které se nacházely i na jeho okrajích, v místech, kde již vystupovaly skály. Nedaleko tarasu ležela v příkopu i kruhová výseč koule z bombardy a další její úlomky, pocházející z projektilu, který dopadl na cestu. Jílový 
výmaz položený na černou vrstvu v př́íkopu ukazuje, že vznikl později, zřejmě v době výstavby vnějšího opevnění, a jeho cílem bylo udržet vodu v př́íkopu. Práce byla odvedena opravdu kvalitně, nebot' i po 600 letech se zde do 12 až $13 \mathrm{~m}$ před bránou celoročně drží voda, která výzkum v př́íkopu velmi ztížila. Jakékoliv stopy po podpěrách mostu, které dokládají stovky hřebů z příkopu, nebyly nalezeny.

Při výzkumu příkopu bylo nejdříve nutné odstranit kamenný zával pocházející z brány. Tvořily ho nejen jednotlivé kameny a vyplavená malta, ale i celé bloky zdiva svědčící o věžovitém charakteru brány. Přes vrstvy bahna jsme se dostali na žlutý jíl tvořící téměř rovné dno a pod ním již vystupující skalní plotny. Ve štítové zdi pod bránou se po odstranění závalu objevil velký otvor s kamenným překladem značných rozměrů, uloženým na vystupující skály po stranách. Otvor zasahuje až pod vlčí jámu uvnitř brány a sloužil k odtoku povrchové vody z hradu (Belcredi 2015, 566 - obr. 10). Zdivo bylo ke skále fixováno mocnou vrstvou vápenné malty. Vedle brány ve čtverci $5 / 5$ vystupuje na povrch skála a poměrně prudce stoupá do čtverce $4 / 5$, kde přiléhá k obvodové hradbě. Ta je lemována žlutohnědou zeminou svažující se do př́ikopu. V délce několika metrů byla v tomto místě obvodová stěna provizorně zesílena nasucho kladenou zdí, vystavěnou před ni.

Na jihozápadním okraji čtverce $6 / 5$ je val vysoký $1,5 \mathrm{~m}$ a ve čtverci $7 / 7$ dokonce $2 \mathrm{~m}$. Jak ukazují černé vrstvy pod ním, byl val rozšířen v průměru o $1 \mathrm{~m}$ dodatečně. Také na protější straně př́kopu, ve čtvercích 4/7 a 5/8 místy vystupuje skála a terén se zvedá. Povrch je opět srovnán jílem. Středem čtverce $4 / 6$ prochází odtokový žlab z otvoru pod bránou, který se oválně rozšiřuje v částech čtverců 5/6-7 a 6/6-7. Zde je nejhlubší část příkopu, jehož dno tvoří čistě skála. Také odtud pochází celá řada nálezů. O silné palbě na hradní bránu hovoří nejen 32 dělových koulí nalezených ve vlčí jámě, ale i před ní. Jedna vlétla dokonce přímo do odtokového otvoru, další zůstala v odtokovém žlabu $1 \mathrm{~m}$ před ním, jiné ve vzdálenostech 3,6 a 5,8 m. Metr od posledně uvedené ležel napínák kuše. Dělová koule pochází též ze čtverce $6 / 6$ spolu s velkým hřebem a kostěnou střenkou nože. Ze čtverců $5 / 7$ a 5/8 pocházejí čtyři podkovy, visací zámek, sedm šipek, dvě dlaždičky, kachle s figurálním motivem a všudypř́ítomné hřeby. Množství nálezů se objevilo i v sousedním čtverci $6 / 8$, a to v několika vrstvách nad sebou, tak jak do př́íkopu padaly či byly vhazovány a př́ekrývány vrstvami usazujících se sedimentů. Řada kovových předmětů z př́íkopu je vlivem prostředí ve velmi špatném stavu, obalena neodstranitelnou vrstvou rzi a hlíny, často přikorodována ke kamenům a neidentifikovatelná.

První předhradí vytvářelo před vjezdem na most do hradu lichoběžníkový prostor o stranách $6,5 \times 8 \times 10,5 \times 12 \mathrm{~m}$, který měl dvě základní funkce, obrannou a komunikační. Pro naplnění termínu předhradí tedy chybí jen hospodářské využití, ale v ohrazeném prŕíkopu se mohli pást koně, popřípadě pobývat další domácí zvířata.

Za otevřeným prostorem dělostřeleckého postavení začínal žlab široký $26 \mathrm{~cm}$ a hluboký $16 \mathrm{~cm}$. Jednalo se o rýhu po uložení trámu. $Z$ vnější strany byla lemována valem, z vnitřní původně obložena velkými kameny. Ve vzdálenosti $2,1 \mathrm{~m}$ od jihozápadního okraje brány se v ní nacházel objekt 554, kůlová jamka hluboká $50 \mathrm{~cm}$. U ní se průběh lomil jižním směrem, avšak zároveň jsme pod navršeným valem odkryli pokračování $\mathrm{v}$ délce $1,2 \mathrm{~m}$ přímým směrem, téměř až okraji valu. Jedná se o linii po obvodovém ohrazení a je otázkou, zda zde došlo ke korekci jeho průběhu, nebo se jedná o pozůstatek staršího opevnění valu. Ve vzdálenosti $2,6 \mathrm{~m}$ od objektu 554 se ve žlabu nacházela další kůlová jamka (objekt 553), hluboká tentokrát $52 \mathrm{~cm}$. Na rozdíl od první byla tato hraněná o stranách $25 \times 30 \mathrm{~cm}$. K zasazení sloupu posloužila upravená skalní štěrbina, do které byl vytesán otvor. Další objekt 551 se nacházel ve vzdálenosti necelých dvou metrů, a to zřejmě z důvodu stoupání terénu. Nalezené jamky ukazují na drážkovou konstrukci ohrazení, tedy na trámy podélně uložené mezi dva sloupy. Bohužel další kůlové jamky jsme v pokračování žlabu neidentifikovali. Průběh ohrazení byl však v zemi jasně doložen, nebot' nejspodnější trám se dostal pod úroveň terénu a zanechal po sobě znatelnou stopu. Délka ohrazení, které se ve středu mírně vlnilo, dosahovalo na valu $18 \mathrm{~m}$. Bylo zakončeno velkou jámou (objekt 555), situovanou do středu severozápadního okraje čtverce 4/11. Okrouhlá jáma, která tvořila jižní nároží palisády, byla technologicky shodná s objekty 301 a 302. Měla při okraji průměr 
$1,8 \mathrm{~m}$ a záhy se zužovala na $1 \mathrm{~m}$. Svislé stěny sahaly do hloubky $1,6 \mathrm{~m}$. Její velikost a hloubka ukazují na značný význam. V ní se ohrazení lomilo a pokračovalo v tupém úhlu v délce $25 \mathrm{~m}$ ke skalnímu nároží u plata před brankou pro pěší a přepažovalo příkop. V jámě mohly být pohodlně ukotveny čtyři sloupy, mezi kterými se obě stěny křížily. Od jejího jihozápadního okraje se táhl v délce $2 \mathrm{~m}$ mazanicí vyplněný žlab široký $20 \mathrm{~cm}$ a hluboký 15 až $20 \mathrm{~cm}$, ve kterém mohla být zapuštěna vzpěra (obr. 2:558). Některé hroudy mazanice byly až $5 \mathrm{~cm}$ velké s výraznými otisky řezanky a její drobné kousky se dostaly i do žlabu po ohrazení. Žár zde byl tak velký, že přepálil i kameny v blízkosti žlabu. To ukazuje na kumulaci značného množství dřeva, z čehož lze usuzovat, že nároží bylo opatřeno strážní věží (srubem), což je ze strategického hlediska naprosto logické. Tomu odpovídá i zvýšený počet nálezů hřebů.

Dvacet metrů jihovýchodně odtud je ve čtvercích B-C/11-12 val rozhrnut do oválné plochy $8 \times 9 \mathrm{~m}$. Její střed je rovný, ale okraj zvýšený. Směrem ke hradu zůstala linie valu zachována, takže byla téměř rovná (obr. 1). Vně však rozhrnutím došlo k zasypání části vnějšího př́íkopu. Přestože jen $20 \mathrm{~cm}$ pod povrchem se objevila žlutě zbarvená zemina tělesa valu, nalezli jsme zde šipku, kování a střepy. K jižní straně objektu směřuje přes druhý př́íkop nasypaný pás zeminy. Podle nálezů dělových koulí středního kalibru v severovýchodní části jádra hradu lze soudit, že se jedná o místo postavení děla a že k zasypání př́íkopu došlo v souvislosti s jeho přesunem na tuto pozici. Důvodem byla potřeba bočního postavení děla vůči věži s břitem, odkud obránci činili oblehatelům značné problémy.

Při výzkumu hradu Skály jsme nalezli 106 kusů dělových koulí a jejich částí, což je zřejmě největší soubor nalezený při archeologickém výzkumu u nás. U 65 z nich, které se zachovaly celé nebo v nadpoloviční velikosti, bylo možné změřit jejich průměr. Pokud jsme se domnívali, že do jednoho děla byly ládovány koule o stejném průměru, pak jsme se velmi mýlili. Celkem jsme nalezli koule 38 různých průměrů od 6,1 do $21 \mathrm{~cm}$, mimo čtyř koulí o hmotnosti $90 \mathrm{~kg}$ do bombardy o průměru $40 \mathrm{~cm}$. Nejvíce byly zastoupeny rozměry 14,3 a $14,4 \mathrm{~cm}$ po sedmi kusech, 14,4 a $14,5 \mathrm{~cm}$ po čtyřech kusech a $15 \mathrm{~cm}$ po třech kusech. Po podrobném zpracování, jehož součástí bylo i vyhodnocení místa nálezu, jsme dospěli k závěru, že u hradu Skály byla nasazena děla o kalibrech 14,8, 16,3, 21 a $40 \mathrm{~cm}$. Pokud tedy hovořím o malých kalibrech, mám na mysli první dvě velikosti. Střední kalibr představovalo dělo o průměru hlavně $21 \mathrm{~cm}$ a koule bombardy měly průměr $40 \mathrm{~cm}$. Koule o malých průměrech nemusí být důsledkem obléhání. Nejmenší z nich o průměru $6,1 \mathrm{~cm}$ byla např́íklad objevena $\mathrm{v}$ tělese penězokazecké pícky. V současné době je připravována práce o dobytí hradu Skály, v níž bude podrobněji pojednáno nejen o koulích, ale i o šipkách, olověných projektilech a dalších militariích.

Nalezený počet dělových koulí je zřejmě jen částečný, nebot' koule byly obyvateli okolních obcí z hradu po staletí odnášeny. V Jimramovských Pasekách byly součástí každé usedlosti a byly používány k čištění komínů.

Opevnění severního nároží hradu (obr. 1:4 a obr. 11)

Druhou zásadní myšlenkou nově budovaného vnějšího opevnění bylo zabezpečení zranitelného severního nároží. Zdivo zde bylo založeno na $3 \mathrm{~m}$ vysoké skále vykloněné vně, poměrně prudce klesající až na úroveň terénu. Její podobu ovlivnili stavitelé, když se ve starším období snažili skálu odstranit. Jelikož toto nároží nebylo možné z žádného místa hradu bránit, bylo slabým článkem obrany. Proto byl zřejmě již ve starším období $7 \mathrm{~m}$ před ním umístěn kruhový útvar vybíhající do př́ikopu, který obepíná jen úzký, ale zato hluboký př́ikop se strmými stěnami (obr. 11:625).

Nároží není zajímavé jen opevněním, ale i úpravami před skálou. Její značná část je do ruda silně ožehnuta žárem. Při zemi je do ní vykután oválný otvor široký $2,8 \mathrm{~m}$, na okraji vysoký $82 \mathrm{~cm}$ a hluboký $1,13 \mathrm{~m}$ (obr. 11:619 a obr. 12). Patrně pochází z druhé fáze budování předhradí, kdy bylo v plánu celou severní skálu odtěžit (Belcredi 2015, 557). Na zemi zde leží řada skalních bloků, které již byly ze skály sneseny, takže otvor může být pozůstatkem po snaze ji podkopat. Po neuskutečnění tohoto záměru došlo na úpravu terénu před skálou. Vzhledem k tomu, 


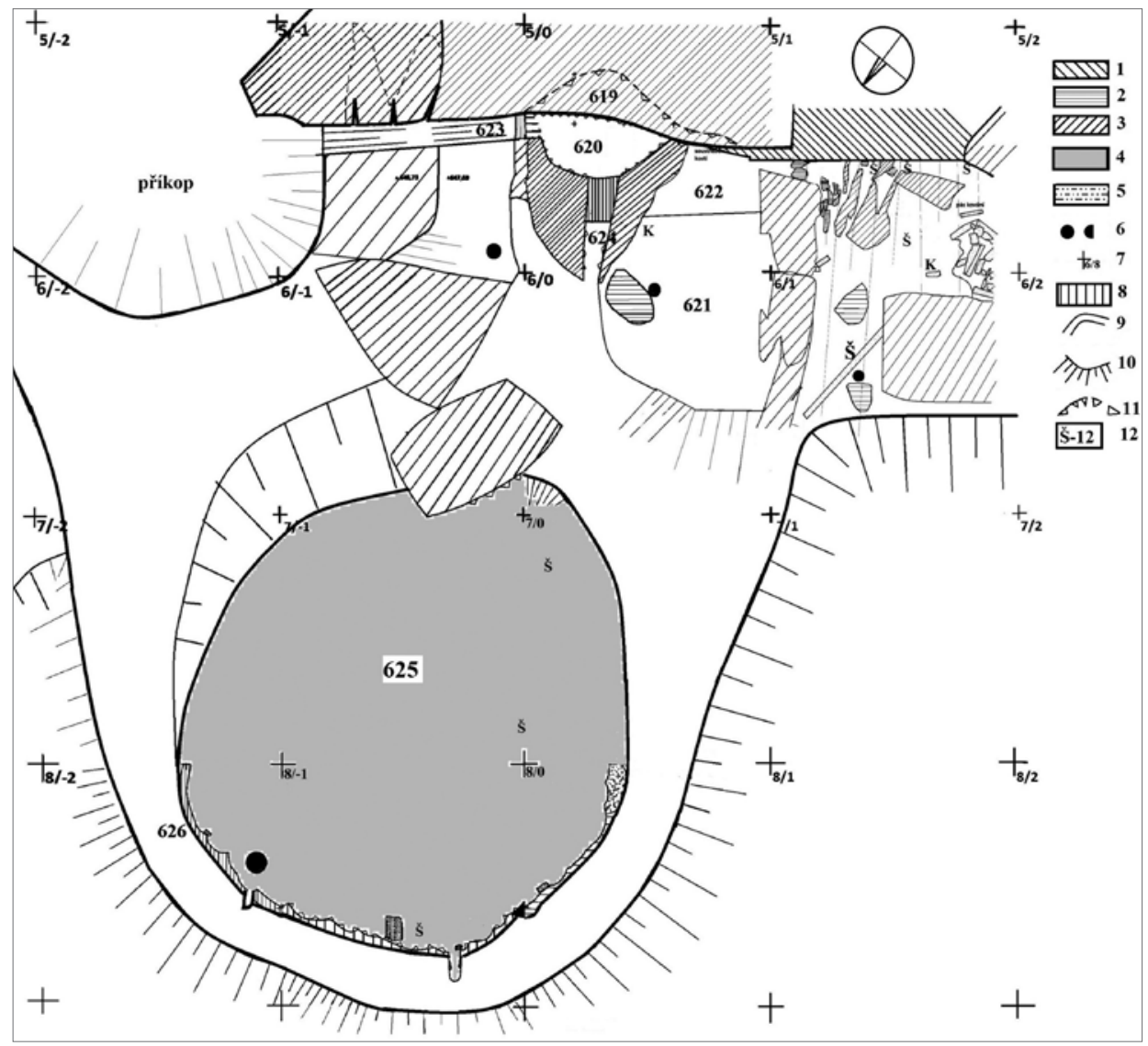

Obr. 11. Půdorysné zobrazení severního nároží hradu s vyznačením objektů a některých nálezů. 1 - zdivo, 2 - kameny, 3 - skála a oddělené kusy skal, 4 - kruhové obranné postavení, 5 - dřevo, 6 - dělové koule a jejich části, 7 - body čtvercové pětimetrové sítě, 8 - jíl, 9 - vrstevnice, 10 - sklon terénu, 11 - hrany terénu a vyznačení zahloubení otvoru ve skále. Nálezy: Š - šipky, K - olověné projektily. Objekty: 619 - otvor do skály, 620 - nádržka, 621, 622 - srovnaná plocha, 623 - př́tokový kanál, 624 - odtokový kanál, 625 - kruhové opevnění.

Abb. 11. Grundrissdarstellung der nördlichen Burgecke mit Kennzeichnung der Objekte und einiger Fundstellen. 1 - Mauerwerk, 2 - Steine, 3 - Felsen und seperate Felsblöcke, 4 - Kreis-Verteidigungsstellung, 5 - Holz, 6 - Kanonenkugeln und ihre Teile, 7 - Punkte des Fünf-Meter-Rasters, 8 - Ton, 9 - Höhenschichtlinie, 10 - Geländeneigung, 11 - Geländekanten und Kennzeichnung der Öffnungseintiefungen im Felsen. Funde: $\breve{S}$ - Pfeile, K - Bleiprojektile. Objekte: 619 - Felsenöffnung, 620 - kleiner Wasserspeicher, 621, 622 - eingeebnete Fläche, 623 - Zuflusskanal, 624 - Abflusskanal, 625 - Kreisbefestigung.

že z otvoru zřejmě vytékala kvalitní voda, byla pod ním vytvořena půlkruhová nádržka o rozměrech $2,55 \times 1,1 \mathrm{~m}$ a hloubce $38 \mathrm{~cm}$ (obr. 11:620). Má sklon k severozápadu a z jejího středu vychází kanál široký $40 \mathrm{~cm}$ a hluboký $22 \mathrm{~cm}$. Ze svahu podél skály od severovýchodu přichází $32 \mathrm{~cm}$ široký kanál o délce $3 \mathrm{~m}$, který mohl nádržku též napájet. Oba kanály byly př́i odkrytí dobře utěsněny jílem, který na severovýchodní straně zabraňoval v přítoku a na severozápadní v odtoku vody.

Severovýchodním směrem, až na samotné skalní nároží, se terén zvedá a do skal zasahuje řada otvorů v podobě jeskyní trojúhelníkovitého průřezu, přirozeně bez nálezů. Otesáním je upraven též samotný roh skály, který zabočuje do severovýchodního příkopu. Před nárožím zůstaly ležet dva mohutné bloky skal, oddělené od severního masivu. Stále je možné určit, ze kterého místa pocházejí. Velikost prvního je $4 \times 1,5 \times 1,2 \mathrm{~m}$. Jednou stranou ještě přiléhá ke skále, 


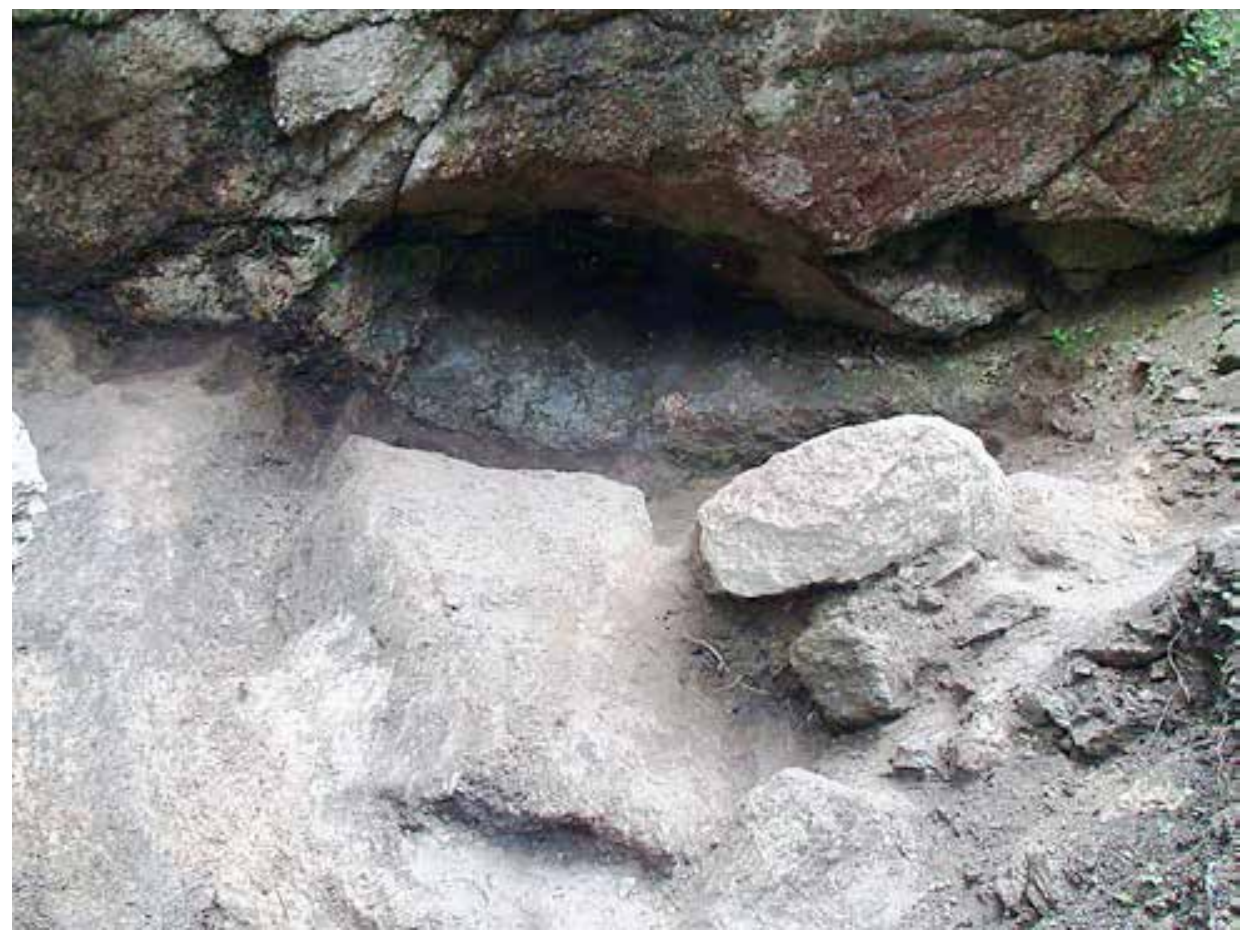

Obr. 12. Otvor vysekaný do skály v severním nároží hradu, pohled od severozápadu (obr. 11:619).

Abb. 12. Aus dem Fels gehauene Öffnung in der Nordecke der Burg, Blick von Nordwest (Abb. 11:619).

zatímco zašpičatělý protějšek byl už od ní odtažen. Tři metry od skály leží další skalní blok, odlomený př́ímo nad otvorem ve skále. Má trojúhelníkovitý tvar o rozměrech 4,45 ×3×1,1 m. Pochází odtud nález pružiny visacího zámku a opět obrovské množství hřebů. Zajímavý byl nález většího počtu hřebů se svitkovou hlavicí na povrchu jednoho z kamenů.

Podél jihozápadní strany nádržky je vytvořena rovná plocha, jejíž část o rozměrech $130 \times 80 \mathrm{~cm}$ je zpevněna maltou, a plochu $4 \times 3 \mathrm{~m}$ pokrývá vrstva žlutohnědé zeminy (obr. 11:621, 622). Je zde vrstva spáleniště s množstvím přepálených hřebů, jeden velký hřeb, velmi pěkný dvoudílný pant a mince moravské ražby. Nacházely se zde i šipky, rukojet' tesáku, olověná kulka, váleček a dělová koule. Může se jednat o podlahu dřevěného přístřešku širokého $3 \mathrm{~m}$, opírajícího se jednou stranou o skálu a sahajícího přibližně $4-5 \mathrm{~m}$ od ní.

Jihozápadní stranu předpokládané stavby ohraničuje menší skalní výstupek, za nímž se situace zcela mění. Terén tvoří hnědá hlína s několika balvany, místy vystupují skály a svažuje se od zdi poměrně prudce do př́kopu. Nedaleko skály ležela vrstva sypké maltoviny, patrně vyplavená ze zdi, a pod ní vrstva uhlíků a ohořelých částí trámků. O jeden z balvanů se zastavila další dělová koule malé ráže, zjevně poté, co se odrazila od zdi. Dále k jihozápadu je ve středu obvodové hradby zapracován velký skalní blok, kolem něhož terén vystupuje na úroveň před obvodovou zdí hradu navazující na bránu (obr. 1).

Předsunuté opevnění severního nároží (objekt 625) je téměř kruhového půdorysu o průměru $9 \mathrm{~m}$ s rovnou horní plochou. Je chráněno půlkruhovým př́íkopem od severozápadu až $8 \mathrm{~m}$ širokým a valem, jehož horní část byla snesena. Na třech stranách padá svah př́íkře do příkopu, na východní přiléhá k odsunutým skalním blokům a na jihovýchodě stoupá k popsané poloze na nároží hradu (obr. 11). Na povrchu objektu se nacházely uhlíky i neohořelé zbytky dřev jdoucí 


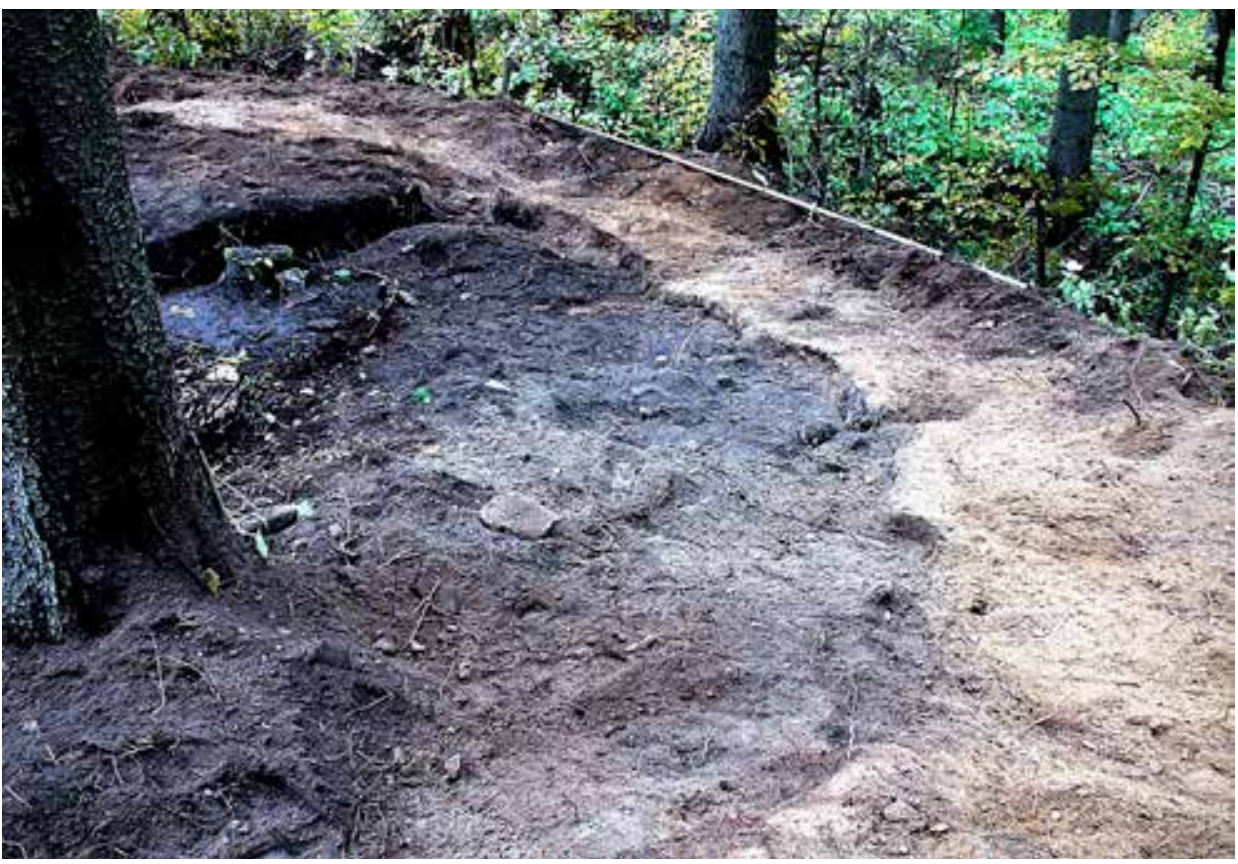

Obr. 13. Kruhové obranné postavení před severním nárožím hradu (obr. 11:625). Na jeho severozápadním obvodu kontrastovala černě zbarvená výplň objektu s půlobloučky rámovanými žlutě zbarveným jílem. Pohled od východu.

Abb. 13. Kreisförmige Verteidigungsstellung vor der Nordecke der Burg (Abb. 11:625). An ihrem nordwestlichen Umfang bildet die schwarz gefärbte Verfüllung des Objektes zu den vom gelbgefärbten Ton umschlossenen Halbkreisbögen einen Kontrast. Blick von Osten.

různými směry, překrývající se i v pravém úhlu, a kousky mazanice. Střední část opevnění byla původně zahloubena a obvod zpevněn $70 \mathrm{~cm}$ širokou a $40 \mathrm{~cm}$ vysokou nasucho kladenou kamennou zídkou. I původní podlaha, ze které místy vystupovaly kameny a skála, byla pokryta spáleništěm, uhlíky a kousky zuhelnatělých dřev, dokládajících požár původní konstrukce.

Snížený vnitřní prostor byl zasypán materiálem z některého ze smetišt', kterých bylo kolem hradu několik. Obsahoval značně strávené kosti, množství keramiky i kovů, např́iklad přezku, dvě stříbrné mince a část podkovy. Hřeby a slitky se nalézaly i v okolních čtvercích. Zajímavé je, že zavážka byla strukturovaná. Střední část byla zasypána popelovitou hmotou s množstvím nálezů, jihovýchodní část hlínou též obsahující nálezy a severovýchodní část hlinitopísčitým materiálem $\mathrm{z}$ rozhrnutého valu.

$\mathrm{K}$ přestavbě tohoto obranného postavení došlo zřejmě v souvislosti s budováním nového obranného systému a důvodem mohl být záměr umístit sem dělo, které potřebovalo rovný povrch. Pro to hovoří i značné snížení (téměř odstranění) valu před objektem, aby nebránil ve výhledu na svah před ním (obr. 1).

Ve vzdálenosti $13 \mathrm{~m}$ od valu byl kolmo na něj nestandardně po svahu dolů navršen velmi zajímavý $10 \mathrm{~m}$ dlouhý, 2 až $2,5 \mathrm{~m}$ široký a stejně vysoký val, který měl bránit v přímém útoku na opevnění (obr. 1, čtverce 11 až 13/-3 až -6). Objekt je nasypán z hlinitopísčitého materiálu obsahujícího množství drobných kaménků a s největší pravděpodobností měl zabránit v přímém útoku na opevnění. Mimo to po celém svahu bylo rozmístěno ohromné množství velkých balvanů až možno říci kusů skal, které měly ztížit pohyb v tomto terénu a tuto funkci plní i dnes.

Úpravy znamenaly změnu ochrany objektu. Na severozápadní straně se po obvodu barevně jasně vyrýsovaly půlobloučky o průměru $25 \mathrm{až} 60 \mathrm{~cm}$, mezi nimiž byly ve dvou místech mezery 
(obr. 13). Takovou stopu po sobě mohly zanechat těsně vedle sebe umístěné kůly palisády, jejichž vnitřní strana se vzhledem k navážce smetiště nezobrazila. Byly umístěny v dostatečné vzdálenosti od okraje svahu a žlutá zemina před nimi byla vypálena v kruzích do lehce načervenalé barvy. Po obvodu se nacházelo též množství uhlíků. To by odpovídalo umístění košů naplněných zeminou těsně vedle sebe, které by snižovaly účinnost střel mírících na palisádu. Nemáme však zkušenost s tím, zda koše s hlínou by po sobě takové stopy zanechaly, i když se jistě nejednalo o běžné koše.

Zatímco odstranění valu hovoří o progresivní obraně, na dně příkopu jsme nalezli stopy po kůlech, které zřejmě měly bránit jednotlivci v jeho překonání. Tedy pasivní obranu, která již nedošla svého naplnění, nebot' objekt byl při obléhání zjevně rozstřílen dělostřelbou. Počet militarií nalezených zde i v bezprostř̌edním okolí nároží dokládá, že toto místo bylo předmětem tuhých bojů. Svědčí o tom olověné projektily a šipky, použití děla k dobytí tohoto místa dokládají nálezy čtyř dělových koulí. V porovnání s baštou na opačné straně čelní zdi hradu je toto opevnění výrazně jednodušší a je otázkou, zda bylo dokončeno podle záměru.

Severozápadní příkop a val před čelní zdí hradu má dnes podobu, která je výsledkem mnoha zásahů do něho (obr. 1). Z původního valu zbylo jen málo. Před čelem se původně nacházel široký př́kop, do kterého terén od hradební zdi klesal v táhlém svahu, a uzavíral ho val, který vzhledem ke svahu terénu před ním vyhlížel z vnější strany strmý a vysoký. Jeho střední část je dnes rozhrnuta do př́íkopu, čímž se jeho výška výrazně snížila a šířka příkopu zúžila. Od obvodové zdi hradu je vzdálen 15 až $20 \mathrm{~m}$, při šířce prŕíkopu 6 až $8 \mathrm{~m}$. V něm se nachází značné množství velkých kamenů až odlomených bloků skal a jeho dno je rovné. Výškový rozdíl mezi prríkopem a rozhrnutým valem dnes není velký. Ve čtvercích $9 / 3$ a $9 / 4$ byl val rozhrnut do širrky $14 \mathrm{~m}$. Kameny, které původně zpevňovaly jeho vrchol, byly použity $\mathrm{k}$ fixaci okraje nad príkopem. Bylo zde vybudováno kruhové postavení o průměru $10 \mathrm{~m}$, jak jsme zjistili, tentokráte pro bombardu.

V př́íkopu, ve čtverci $9 / 5$, jsme $40 \mathrm{~cm}$ pod povrchem narazili nejen na vodu, ale i na černě zbarvenou vrstvu smetiště pokračující pod těleso bašty, které bylo i tímto směrem rozšířeno. Nacházelo se v něm značné množství nálezů, především keramiky a hřebů, ale i velmi pěkná ostruha. Mezeru mezi okrajem valu a tělesem bašty částečně vyplňuje velký kámen o rozměrech $7 \times 4 \mathrm{~m}$. Jen $3,5 \mathrm{~m}$ východně od něj se nachází další rozměrný trojúhelníkovitý kámen, který zabírá celou horní polovinu čtverce $10 / 5$ a zasahuje i do smetiště ve čtverci $9 / 5$ s množstvím nálezů. Ještě více se jich objevilo ve čtverci 10/6. Pochází odtud střep poháru zdobený vtlačovaným ornamentem pětilisté růže, dvě přezky, celá podkova a množství hřebů. Mezi zmíněnými dvěma kameny jsme odkryli začátek kanálu směřujícího k severozápadu. Ve čtverci $12 / 5$ je val oválně zakončen a příkop se stáčí vně. Zde začíná mísovitá terénní deprese, která v délce $10 \mathrm{~m}$ tvoří mezeru ve valu. Tudy kanál, který vedl přes čtverce 10 a 11/6 do čtverců $12 / 5$ a 6 , rozšířeným ústím kolmo na hradební zed’ opouštěl opevněný areál. Kanál byl $90 \mathrm{~cm}$ hluboký, na povrchu $1,2 \mathrm{~m}$ široký a na jeho $30 \mathrm{~cm}$ širokém dně místy vystupovala skála. Jedná se o neobvyklou úpravu terénu před hradem, nebot' likvidací střední části valu byl otevřen vstup do př́kopu, a tím vznikla možnost snadného přístupu až k obvodové zdi hradu. Při bližším zkoumání však zjistíme, že mohlo jít o geniální tah obránců s účelem nasměrovat útočníky prrímo pod střílnu bašty, a to v úzkém kanálu, kde byl velice ztížený pohyb. Odstranění valu právě v tomto místě totiž otevřelo obráncům bašty výhled na celý severozápadní svah před hradem, a tak mohli mít útočníky stále na mušce.

Jihozápadní stranu deprese vymezoval ve čtverci 11/8 výrazný pahorek s povrchem srovnaným téměř do kruhu o velikosti 5,5 ×5 m. Byl rozhrnut severozápadním směrem, kde vytvořil prudký svah. Jeho povrch byl vydlážděn kameny, dlaždicemi a cihlami a okraje vysypány štěrkem. Je školním prŕíkladem úpravy povrchu obléhacího postavení, tentokráte pro dělo malé ráže.

V nevelké vzdálenosti od sebe shledáváme tedy na valu dvě palebná postavení děl různého kalibru. K jejich dopravení na tato stanoviště byla pochopitelně vybrána nejjednodušší cesta, která vedla přes zasypání kanálu a vytvoření dvou pozvolných ramp vycházejících z úrovně 
vnějšího terénu a vystupujících na val. K zasypání byl použit materiál z valu, okolní zemina, jak černá z prostoru před ním, tak ze smetiště s množstvím nálezů a přirozeně také řada velkých kamenů. Ty byly na jeho dno vhozeny jako první. Na západní straně náspu bylo nalezeno značné množství militarií, ale i jiných nálezů včetně mincí.

Od místa upraveného pro post menšího děla směrem k jihozápadu val mezi čtverci 12/10 až $8 / 13$ v důsledku stavby nové prŕístupové cesty zcela zmizel. Mezi ním a ukončením druhého valu u původní př́ístupové cesty vznikla $27 \mathrm{~m}$ široká mezera. Hlína z valu byla patrně použita na rozšíření valu pod baštou.

Na severovýchodní stranu se př́ikop výrazně zužuje a zařezává do zahloubeného prostoru před kruhovým opevněním severního nároží. Jak bylo uvedeno, val je zde téměř odstraněn, takže od př́kopu má podobu jen svahu terénu. Teprve na severovýchodní straně opevnění nabývá svoji výšku a stáčí se k severovýchodu, kde přiléhá téměř až ke skalám. Je to zřejmě jediná část, kde se val zachoval v původní podobě, pokud ovšem je jeho stočení kolem předsunutého opevnění severního nároží původní. Mezi ním a skalami zde zůstala dvoumetrová mezera, kterou je možné projít do severovýchodního př́íkopu.

Kovárna na barevné kovy (obr. 1:6)

Ve čtverci 9/9, $8 \mathrm{~m}$ před bránou prvního předhradí, se cesta stáčí k jihozápadu. Pod ní je plocha vyplněna značným množstvím kamenů velkých rozměrů naskládaných těsně vedle sebe, vyplňujících i téměř tři čtvrtiny čtverce 11/9. Zde se mezi nimi objevilo množství měděné a bronzové strusky, kousků bronzu, a dokonce i kapka zcela čistého cínu. Při jeho severozápadní straně jsme zaznamenali značný výskyt bronzových slitků, kuliček, okují, kapek bronzu a také poškozené předměty z těchto materiálů. Pochází odtud i násuvný klíč $\mathrm{s}$ velmi jednoduchou bradou, celá podkova, šipka, pant, a zasahovala sem i vrstva keramiky. Na severozápadním okraji čtverce 10/9 výskyt slitků i keramiky končil a v jeho jihozápadní části se objevila vrstva propálené mazanice, uhlíků a kamenů vykazujících podlehnutí tak vysokému stupni žáru, že se rozpadaly. Ve všech čtvercích jsme zde nacházeli roztř́íštěné dělové koule, dokládající těžký boj o předhradí.

Nálezy po celou dobu avizovaly existenci výhně. Tu jsme nalezli v západním rohu čtverce 11/9, bohužel značně narušenou kořeny okolních stromů, nebot' se nacházela velmi nízko pod povrchem (obr. 2:591). Od severozápadu a jihozápadu ji lemovala vrstva mazanice s uhlíky. V jejím středu ležela větší část malé dělové koule, a mince. Zařízení se nacházelo téměř na úrovni valu, jen $5 \mathrm{~m}$ od palebného postavení. Mezi nálezy dominuje krásný malý otočný klíček visacího zámku a $20 \mathrm{~cm}$ dlouhý úlomek podélně rozpůlené trubky, snad hlavně hákovnice. Také v tělese pece se nacházely bronzové slitky a mimo jiné z něho pochází i ploché kování o rozměrech $10 \times 10 \mathrm{~cm}$.

I když objekt nebyl dochován v nejlepším stavu, bylo možné rozpoznat jeho původní členění. Celková délka dosahovala $3,7 \mathrm{~m}$, šiřka až $1 \mathrm{~m}$. Jeho ústřední částí byla výheň rozměrů $1,6 \times 1 \mathrm{~m}$. Neuvěřitelně mocný výmaz v síle 10 až $15 \mathrm{~cm}$ byl natažen na čtyři vrstvy plochých kamenů. Pod nimi byla vrstva jílu, který srovnával členité podloží. Severozápadní okraj výhně byl obložen velkými kameny do mírného oblouku. Z jejich vnější strany $\mathrm{k}$ nim byla natlačena vrstva žlutého jílu. Výmaz byl natažen v úrovni terénu, takže kovář musel pracovat ve značném předklonu či vkleče.

Na jihovýchodní straně do výhně ústil 24 cm široký kanál, ohraničený na hranu postavenými kameny. Oba jeho konce vykazují výrazné barevné rozhraní. V ústí výhně je jasná kontura jejího rudě vypáleného výmazu a černě zbarvené střední části, na opačné straně černá barva střední části zachází pod vrstvu žlutého jílu třetí části nataženého až na velký balvan, kterým celé zařízení končí. Velikost tohoto výmazu je 1,5 × 1 m a tvoří nepravidelný sedmiúhelník, což určitě není jeho původní tvar. Lze předpokládat, že na této ploše stál měch, který hnal vzduch kanálem mezi kameny do výhně. Proto je povrch pod ním zbarven žlutě, povrch kanálu černě 


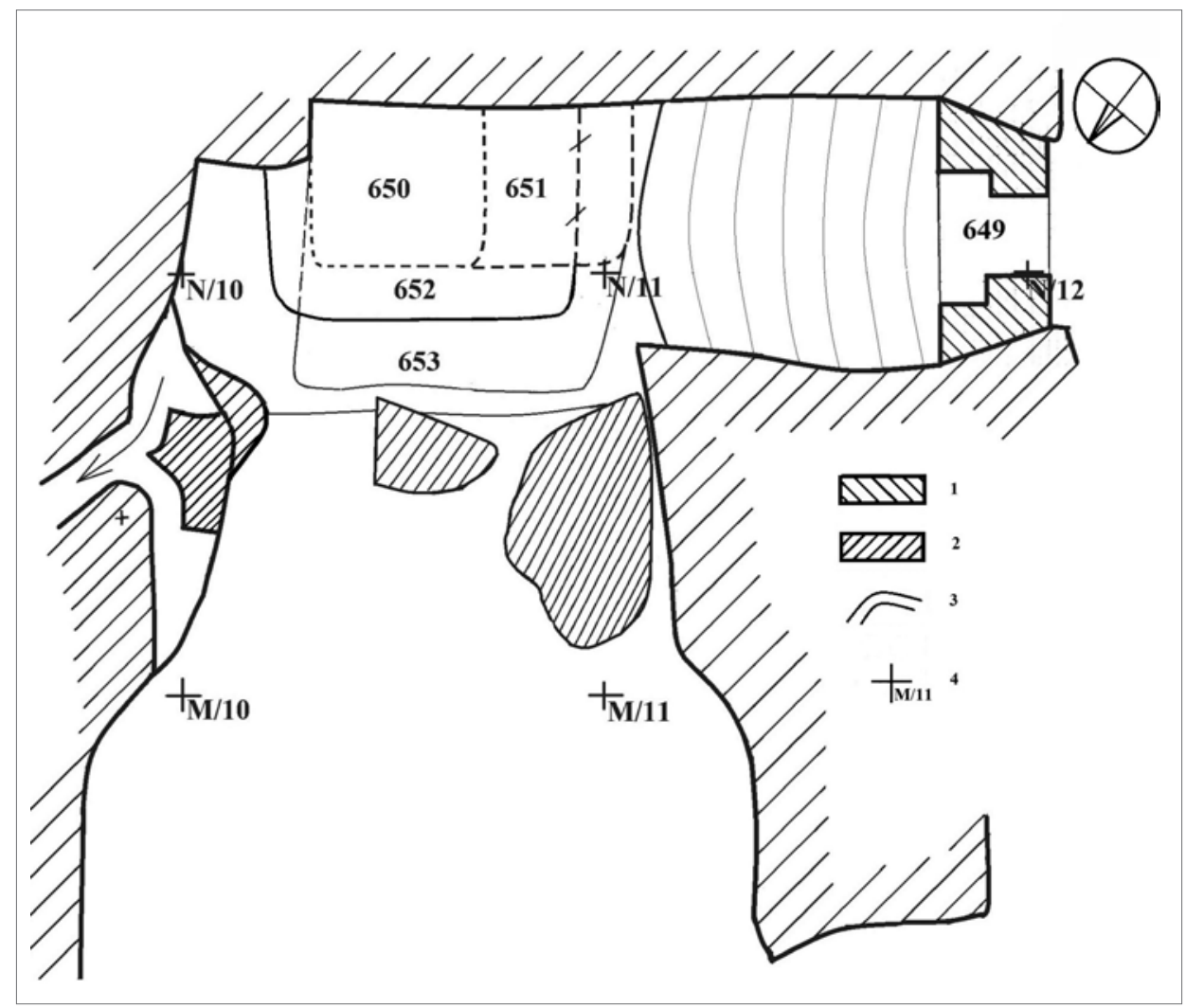

Obr. 14. Půdorysné zobrazení plochy vápenky s vyznačením objektů (obr. 1:9). 1 - zdivo, 2 - skála a oddělené kusy skal, 3 vrstevnice, 4 - body čtvercové pětimetrové sítě. Objekty: 649 - vstup, 650 - vrstva čistého vápna, 651 - vrstva znečistěného vápna, 652 - zpevněná podlaha, 653 - podklad podlahy.

Abb. 14. Grundrissdarstellung des Kalkofens mit Kennzeichnung der Objekte (Abb. 1:9). 1 - Mauerwerk, 2 - Felsen und separate Felsblöcke, 3 - Höhenschichtlinien, 4 - Punkte des Fünf-Meter-Rasters. Objekte: 649 - Eingang, 650 - Schicht reinen Kalks, 651 - Schicht verunreinigten Kalks, 652 - befestigter Fußboden, 653 - Fußbodenbett.

a výhně jasně rudě. Stejně jako výheň i tato plocha byla vícekrát opravována, o čemž svědčí prolínající se vrstvy.

Vzhledem k množství nalezených hřebů a uhlíků lze soudit, že výheň byla pod střechou patrně otevřeného přístřešku.

\section{Hradní smetiště}

Při tak podrobném archeologickém výzkumu jsme přirozeně nalezli i řadu smetišt', z nichž o několika již byla zmínka. Pochopitelně, že jsme zjistili také polohu původního a nejrozsáhlejšího smetiště z dob pánů ze Skal. Vzhledem k nevšednímu zájmu „detektorářư“ o něj však zde jeho lokalizaci neuvádím. Obsahovalo řadu zajímavých nálezů. Mimo keramiky se objevily dlaždice, celé cihly různého tvaru a velikosti a byla sem vyhozena i celá kachlová kamna s gryfem. Z kovových předmětů jsme nalezli např́klad šipky, klíč k závěsnému zámku, mince, kousek stříbrného tenkého přívěsku, ostruhy, z nichž jedna byla plátována měděným plechem, takže po vyčistění by zářila jako zlatá, aj. Samozřejmě tu bylo vyhozeno i značné množství kostí, z nichž některé byly nasekány zcela nadrobno. 


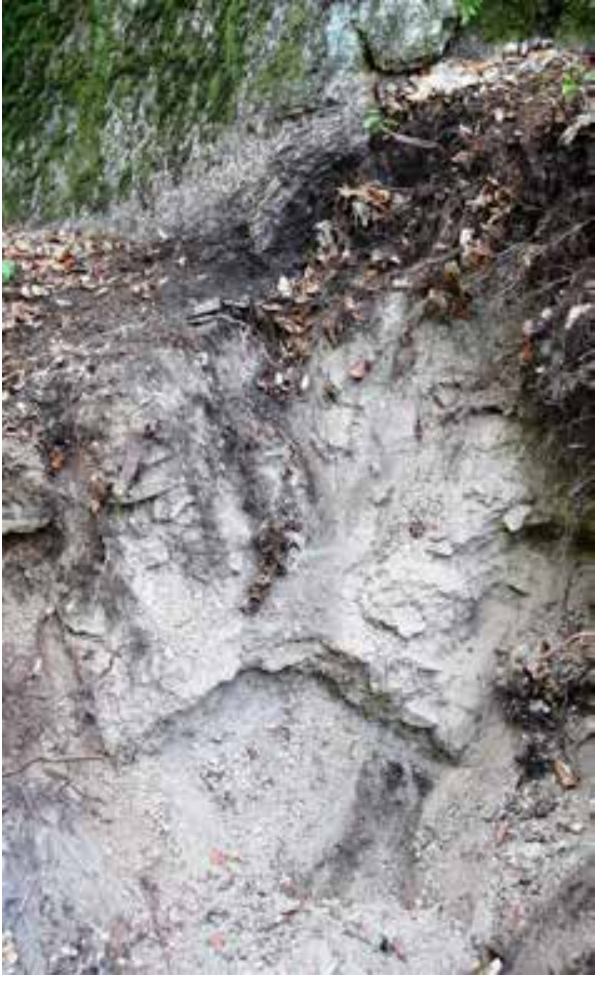

Obr. 15. Mocná vrstva čistého vápna (obr. 14:650), pohled od severozápadu.

Abb. 15. Mächtige Schicht reinen Kalks (Abb. 14:650), Blick von Nordwest.

červeně zbarvená vrstva mazanice. Za brankou terén v šířce $2,5 \mathrm{~m}$ a délce $3,6 \mathrm{~m}$ stoupá, avšak místo schodů zde nacházíme jen velmi hrubě otesaný povrch skály. Stoupání je ukončeno ostrým zlomem a na zarovnaném povrchu začíná černá vrstva s nálezy především obrovského množství hřebů. Mimo něj odtud pochází pouze jeden nůž.

Zatímco na jihozápadní straně se skála záhy lomí k severozápadu, na opačné pokračuje $\mathrm{v}$ délce $7,4 \mathrm{~m}$ v př́ímce a je otesána do poměrně hladké svislé stěny, ukončené od severovýchodu téměř pravoúhle skalním blokem o délce $72 \mathrm{~cm}$. Za ním se severovýchodní skála několikrát lomí a ustupuje $\mathrm{k}$ severu. Není zde vysoká a jednou z mezer bylo možné nejen vystoupit na malou plošinku s vyhlídkou na jihovýchodní svah, ale vedla tudy i cesta - spojnice do hradu. Vstupovalo se do něho zadní brankou vedoucí do paláce.

Zatímco ve vstupu do vápenky jsme na podlaze odstraňovali jen čtyřiceticentimetrový zával, podél otesané skály stoupal až na $2,2 \mathrm{~m}$ ve východním rohu. Po odstranění zásypu se před námi objevila $1,7 \mathrm{~m}$ vysoká a $2,3 \mathrm{~m}$ široká vrstva téměr čisté vápenné hmoty obsahující i velmi tvrdé hroudy vápna. Do její horní vrstvy propadlo několik plochých kamenů (obr. 15). Vápenná vrstva se svažovala od skály směrem dovnitř, takže $1,6 \mathrm{~m}$ od ní měla výšku $1,1 \mathrm{~m}$ a končila ve vzdálenosti dvou metrů a výšce $70 \mathrm{~cm}$ (objekt 650). Pokračovala směrem $\mathrm{k}$ bráně, kde je však proložena téměř souvislou vrstvou plochých kamenů a hlíny (objekt 651). Svislá skalní stěna a nároží je žárem vypáleno do temně rudé barvy.

Pod vrstvou vápna se objevila neuveřitelně rovná podlaha zbarvená šedo- až fialovočerně, opět se stopami po silném žáru. Tvořila ji souvislá vrstva drobných valounů uložených těsně vedle sebe, takové tvrdosti, že se motyčka od nich pouze zvonivě odrážela, jako by byly do země 


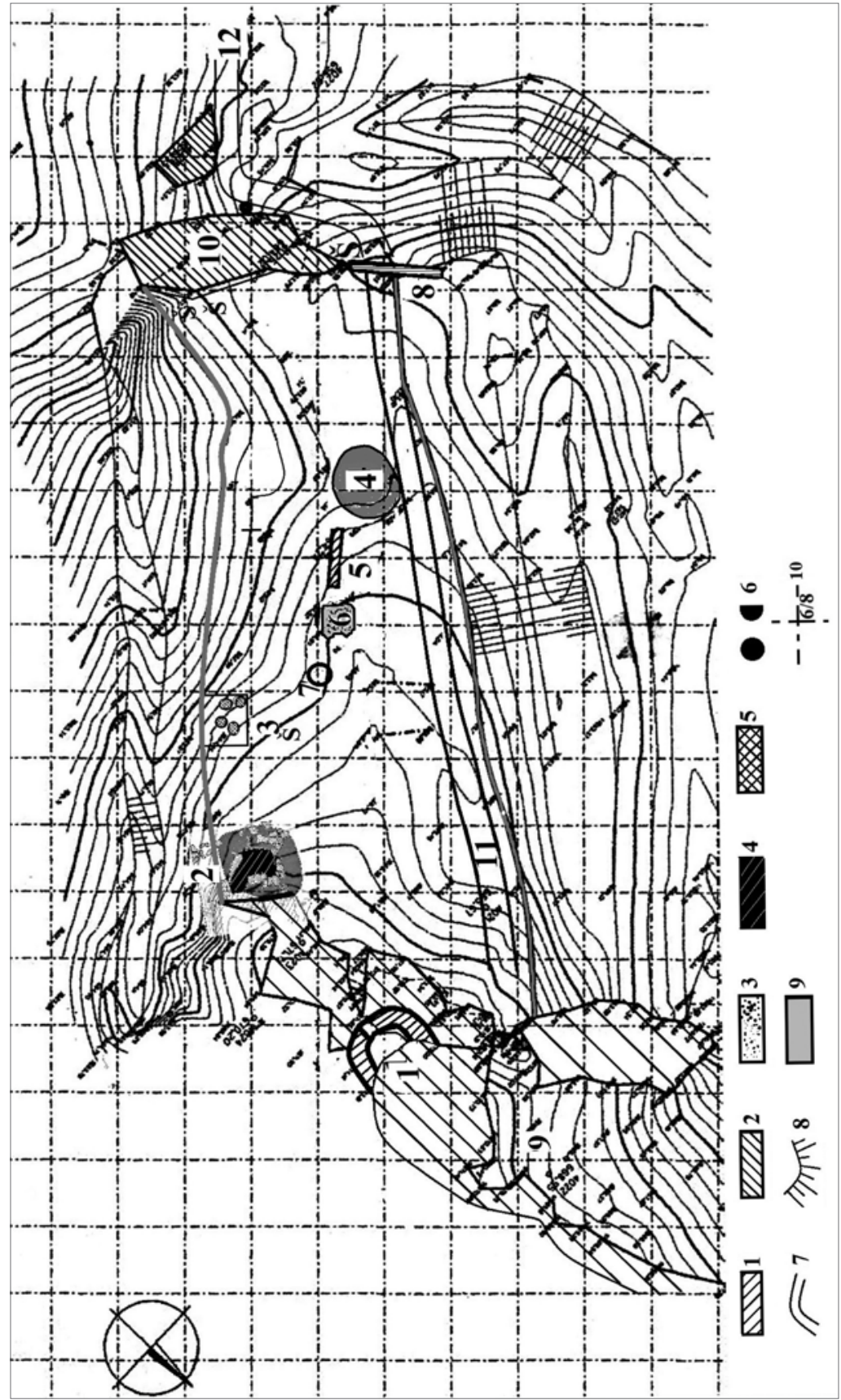

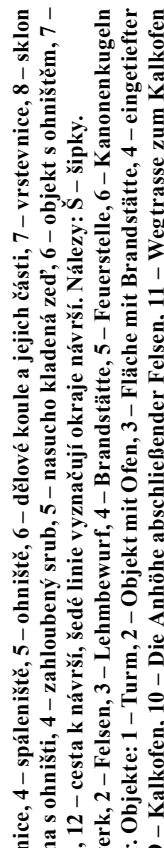

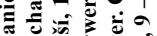

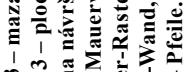

की

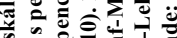

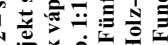

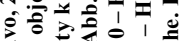

1 远

1 -

它 1 के

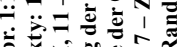

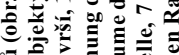

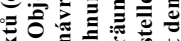

过河

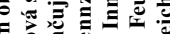

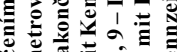

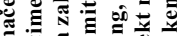

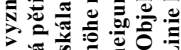

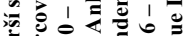

西

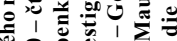

은

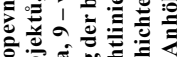

응

引

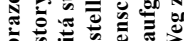

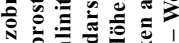

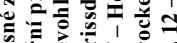

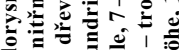

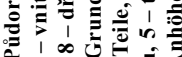

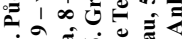

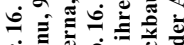

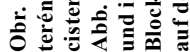


zatlučeny. Vrstva sahala až do vzdálenosti 2,5 m od skály a mírně se od ní odkláněla (objekt 652). Na ní spočívala podivná vrstva prachu tmavošedé barvy. Podlaha byla položena na vrstvu černé tvrdé zeminy s drobnými kameny mocnou 20 až $40 \mathrm{~cm}$, podle výše skalního podloží (objekt 653). To bylo srovnáno vrstvou jílu do vzdálenosti $1,65 \mathrm{~m}$ od skály. Dále se skalní podloží lomilo do svahu, kde podlahu vyrovnávaly kameny o velikosti $10 \times 10 \mathrm{~cm}$ zatlačené do vrstvy žlutého jílu. Takto vytvořená podlaha byla ve vzdálenosti $3,5 \mathrm{~m}$ od skály ukončena rovnou plochou vymazanou žlutým jílem s velkými kameny. Ve vzdálenosti 3,8 až 4,2 m od čelní skály je nejužší místo široké jen $1,8 \mathrm{~m}$, které lemují dva velké kameny o velikosti $130 \times 40 \times 70 \mathrm{~cm}$. Zde patrně objekt končil, nebot' černě zbarvená podlaha $\mathrm{z}$ drobných kamenů přechází do hnědé hliněné vrstvy. Dále se prostor opět rozšiřuje, takže $5 \mathrm{~m}$ od strmé skály je jeho šířka $4 \mathrm{~m}$ a ve vzdálenosti $6,4 \mathrm{~m}$ dokonce $9,9 \mathrm{~m}$. Ve vzdálenosti $9 \mathrm{~m}$ od skály začíná na západní straně prudký svah a celý prostor uzavírá od severozápadu skála ve vzdálenosti 25 až $30 \mathrm{~m}$. Čím více jsme se vzdalovali od strmé skály, tím menší byla vrstva sutě.

Mocná vrstva nalezeného čistého vápna je situovaná do uzavřeného prostoru $4 \times 3,5 \mathrm{~m}$, do něhož se vstupuje brankou, kterou bychom očekávali spíše u obytné stavby. Doklady silného žáru na skalách a podlaze budí dojem, že zde vápno bylo přímo páleno. Podle intenzity propálení skal se výroba soustřed'ovala do východního rohu jihovýchodní stěny pod svislou skálu. Stopy ohně končí ve vzdálenosti $2 \mathrm{~m}$ od skály, stejně jako výskyt vápna. Na místě mohlo zůstat až sedm kubíků vápna, což je poměrně překvapivé, uvážíme-li, že poslední stavební činnost s jeho použitím na hradě mohla probíhat kolem roku 1410. Od doby jeho posledního použití do zániku hradu tedy uplynulo i 30 let. K pozdějším úpravám bylo totiž použito výhradně dřeva. Nalezená vrstva kamenů bohužel nedokládá v tomto místě existenci vápenných pecí. Proto, i přes značné doklady žáru, nelze zcela vyloučit, že se jednalo „pouze“ o deponie vápna, k jehož pálení docházelo mimo hrad. Množství kamenů však staví otázku o jejich původu. Je malá pravděpodobnost, že pocházely z věže nad „,vápenkou“, nebot’ ta je od ní v poměrně velké vzdálenosti a obrácena na druhou stranu. Nálezy značného množství hřebů a nevelké množství mazanice hovoří o tom, že se zde nacházely dřevěné př́ístřešky.

Na návrší bylo možné zjistit též průběh přístupové cesty $\mathrm{k}$ tomuto místu, která nebyla poškozena žádným dodatečným zásahem. Do areálu vstupovala na opačném konci návrší vzdáleném od „vápenky“ $60 \mathrm{~m}$ krátkou strmou rampou, která překonávala převýšení mezi terénem pod návrším a jeho vrcholem. Vedle ústí cesty je totiž návrší zakončeno kolmou skalní stěnou vytvářející značný výškový rozdíl. Cesta uvnitř byla vedena po severozápadním okraji návrší, téměř po vrstevnici. Končí před šikmo ležícím skalním blokem velikosti 4,5 × 1,8 × 1,2 m, nacházejícím se $7 \mathrm{~m}$ od prahu branky do ,vápenky“. K prahu se cesta zvedala rampou o délce 7,5 $\mathrm{m}$, která musela překonat výškový rozdíl $1,2 \mathrm{~m}$. Poloha kamenného bloku ukazuje, že byl na cestu před branku natažen zcela záměrně. Náklad vápna musel být $\mathrm{v}$ každém prŕípadě do areálu nošen, nejspíše v koších.

Sondy položené na několika místech přes cestu zjistily, že její šiřka byla $1,7 \mathrm{~m}$. Místy je terasovitě nasypaná a její vnější, tedy severozápadní strana, je zpevněna kameny, zatímco na opačné se nachází jen sypká zemina. Zajímavé je zjištění, že v určitých vzdálenostech od sebe se po jejích okrajích nacházejí proti sobě vždy dva kameny postavené na hranu, které cestu vymezovaly. Alespoň tak lze soudit na základě čtyř z nich, které jsme nalezli. Z povrchu cesty pochází šipky, hřeby a dva háčky.

Vápno bylo obecně rozšířeným desinfekčním prostředkem, takže mohlo být na hradě používáno průběžně k zasypávání prevétů či smetišt'. Vzhledem k tomu, že stavby v jádru hradu byly omítnuty, mohly být též natírány vápnem. Málo pravděpodobné je, že by se jednalo o deponii pro nějakou další zděnou stavbu, a ještě méně pravděpodobnější, že bylo připraveno na zasypání prrípadných hrobů, i když k tomuto účelu se běžně používalo.

Vápenec byl s největší pravděpodobností získáván z jediného známého zdroje v okolí, který se nachází za Jimramovem ve směru na Poličku, tedy ze vzdálenosti zhruba $6 \mathrm{~km}$. 
Jižní věž (obr. 1:8 a obr. 16:1)

Na jižní konec skal nad vápenkou je situována půlkruhová věž nasměrovaná na obranu návrší, kudy přicházela cesta do „vápenky“. Je zajímavé, že složení její malty odpovídá maltě ze stavby nejstaršího období, tedy jádru hradu. Věž střežila nejen hřeben kopce, ale kontrolovala i cestu podél toku Fryšávky v údolí, tedy evidovala každého, kdo se po ní pohyboval.

Věž tvoří elipsu o rozměrech $6,3 \times 5,5 \mathrm{~m}$ při velikosti vnitřního prostoru $2,5 \times 3 \mathrm{~m}$. Obvodová zed' je poměrně vysoká, místy stavěná jakoby trochu chaoticky a přiléhá ke skále, která tvoří její severovýchodní stranu. Síla jejího zdiva není po celém obvodu stejná. Nejsilnější $2,5 \mathrm{~m}$ - je na jižní straně, kterou je obrácena k větší části návrší. V jejím středu je zazděný $1 \mathrm{~m}$ široký původní vstup, nasměrovaný nad mezeru vylámanou ve skále pod ním. Líce vstupu jsou po celé hloubce zdiva jasně patrné. Směrem jihovýchodním se zdivo výrazně zužuje až na $1,3 \mathrm{~m}$. $Z$ této strany totiž nehrozilo žádné nebezpečí, nebot' svah zde strmě padá několik set metrů k říčcce Fryšávce. S šířkou zdiva koresponduje i její výška. Původní je zachována pouze v jediném místě na severozápadní straně, kde dosahuje $1,57 \mathrm{~m}$, v místě vstupu má již jen $1,3 \mathrm{~m}$ a nejnižší

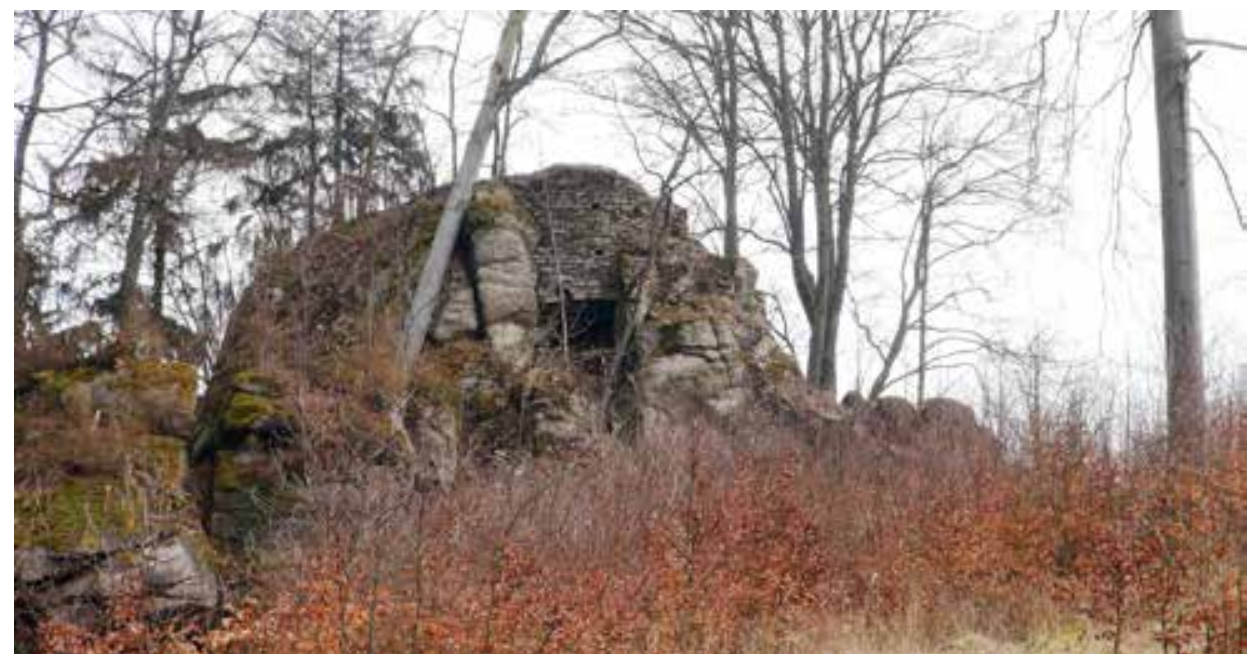

Obr. 17. Jižní předsunutá věž (obr. 16:1), pohled od jihozápadu.

Abb. 17. Vorgezogener Südturm (Abb. 16:1), Blick von Südwest.

zdivo je na jihovýchodě, pouhých $82 \mathrm{~cm}$. Skála na severovýchodní straně, ke které je věž vyvázána, vyčnívá nad podlahu $1,5 \mathrm{~m}$.

Uvnitř věže se pod $50 \mathrm{~cm}$ hrabanky nacházela sut', pod kterou jsme místy nalezli ještě zachovalou dlažbu. Nejlépe se dochovala na severozápadní straně, kde po obvodu byla vytvořena lávka a vlastní podlaha byla ještě o něco níže a v malé části na severovýchodní straně. Největší díru do ní „turisté“ vykutali v jižní části u hradby, kde se prokopali až $50 \mathrm{~cm}$ pod ni. Lávka byla po obvodu zjevně vyzděna proto, že pouze z ní bylo možné pohlédnout přes širokou zed', nebot' při postavení na podlaze není přes ni terén vidět. To však zároveň skýtalo obráncům dobrou ochranu před př́ípadnými střelami z vnějšku. Pod pařezem suchého stromu jsme nalezli střepy středověkého poháru a hraněné skleněné nádoby ze 17. století.

Zbytky zdiva se zachovaly též na skále, zhruba v polovině její výšky, kde mohou být pozůstatkem jak snahy zabránit ve výstupu na ni, tak př́ístupu vzniklého po zazdění původního 
vstupu. Na úrovni skály „lidé“ skrz celé její těleso vylámali tak velký otvor, že je ohrožena samotná její existence.

Zhruba na střed věže směřuje 5,6 m hluboká mezera vylámaná ve skále. Je to jediné místo, kde je možné dostat se až pod samotné zdivo věže (obr. 17). V mezeře se nacházel kuželovitý zásyp o několika vrstvách. Již na počátku odkryvu v něm byl nalezen úlomek podkovy a hřebíky. Spára široká na okraji 1,6 m se směrem dovnitř zužuje. Nálezový horizont se projevoval $5 \mathrm{~cm}$ mocnou černou vrstvou zeminy. V ní jsme, zcela na okraji spáry, nalezli osmičkovitou petlici a nedaleko ní malé kování závěsu dveří se dvěma hřeby a množství hřebů. Ve vzdálenosti 2,2 a $2,6 \mathrm{~m}$ od jejího okraje pak čtyři šipky a dva olověné projektily, zřejmě doklady bitvy o věž. Vše nasvědčuje tomu, že prostor byl vylámán za účelem umístění žebříku, po kterém byla věž původně př́ístupná. Na základě nálezu petlice a závěsu dveří se lze domnívat, že tento prostor bylo možné uzavřít, a mohl tedy sloužit i k jinému účelu, a to i po přeložení přístupu na věž. Vzhledem k tomu, že původní vstup byl z čela věže, tedy z nejzranitelnější strany, je logické, že $\mathrm{v}$ pozdější době byl zazděn a nahrazen bezpečnějším.

Opevněné návrší (obr. 1:10 a obr. 16)

Skála s věží uzavírá od severovýchodu návrší nad hradem táhnoucí se k jihu v délce $55 \mathrm{~m}$ a mající v průměru šířku $20 \mathrm{~m}$. Povrch byl srovnán do roviny mírně skloněné ke hradu. K němu je návrší orientováno téměř pravoúhle a tyčí se nad ním ve vzdálenosti 80 až $130 \mathrm{~m}$. Směrem ke hradu je obehnáno dvojitým příkopem a valem, končícími na nejvzdálenějším místě pod kolmou skálou. Zde jsou valy mohutné a př́ikopy hluboké. O pár metrů dál je situace zcela jiná, nebot' vnější prríkop končí a vnitřní vyhlíží nedokončeně.

Na návrší jsme zjistili několik objektů. O jižní věži již řeč byla. Pod ní je skála v délce $3 \mathrm{~m}$ zarovnána a na tomto místě jsme zaznamenali výskyt propálené mazanice, která se po odkryvu ukázala v ploše $4 \times 3 \mathrm{~m}$ o mocnosti $5 \mathrm{~cm}$ (obr. 16:2). Pod ní se objevila další vrstva o síle $12 \mathrm{~cm}$ $\mathrm{s}$ výmazem, který signalizoval ohniště o velikosti $1,8 \times 1,1 \mathrm{~m}$. Podlahu tvořila černě zbarvená vrstva 2 až $2,5 \mathrm{~cm}$ tenká, končící jen $1,5 \mathrm{~m}$ od hrany svahu. Ze dvou stran byl objekt vymezen řadami kamenů, na jižní se objevila $2,7 \mathrm{~m}$ dlouhá destruovaná řada kamenů dosahující až ke hraně svahu. Jihovýchodní roh byl zapuštěn do pravoúhle vytesané skály tvořící poslední stranu stavby. Celý objekt byl založen na vrstvě žluté zeminy, která srovnala terén do roviny. Kameny v jeho okolí budily dojem dláždění. Ve vrstvě mazanice se nacházely hroudy s výraznými otisky prutů, což nás utvrzuje v přesvědčení, že zde stála pec, pravděpodobně krytá lehkým př́stř̌eškem zapřeným o skálu. Rozměr stavby mohl být $3 \times 4 \mathrm{~m}$. Nenacházejí se tu však žádné kosti a jen zanedbatelné množství atypických střípků. To znamená, že nesloužila k př́ipravě pokrmů, ani jako místo jejich konzumace.

Celá plocha návrší byla systematicky prozkoumána křižnými sondami ve vzdálenosti $5 \mathrm{~m}$ od sebe. Na řadě míst vystupuje skála až k povrchu nebo se na ní nachází jen nepatrná vrstva hrabanky. V průměru vrstva zeminy nad nálezovým horizontem nepřesahovala $25 \mathrm{~cm}$.

Na jihovýchodním okraji návrší se ve vzdálenosti $12 \mathrm{~m}$ od skály s věží objevila $20 \mathrm{~cm}$ pod povrchem vrstva propálené mazanice. Následně jsme odkryli plochu 4,2 × 4,6 m s červeně zbarvenými kruhy na podloží, doprovázenými uhlíkatou vrstvou a větším množstvím kamenů dosahujících k jihovýchodní hraně svahu, kterou zpevňovaly (obr. 16:3). Nejvýraznější dva kruhy o průměru $50 \mathrm{~cm}$ se nacházely v samotném středu. Byly překryty mazanicí o mocnosti $10 \mathrm{~cm}$, pod kterou leželo zuhelnatělé prkno o šířce $20 \mathrm{~cm}$. Další dva červeně zbarvené kruhové objekty jsme nalezli jen $1,56 \mathrm{~m}$ od nich. Také nad nimi se nacházela pěticentimetrová vrstva mazanice a nedaleko nich řada opálených kamenů, pravidelně naskládaných do roviny. Větší koncentraci mazanice jsme zaznamenali též kolem kůlové jamky čtyřhranného průřezu velikosti $20 \times 20 \mathrm{~cm}$, nacházející se opodál. I zde byla pod mazanicí vrstva uhlíků. Kameny v celé ploše byly zasazeny do vrstvy jílu, jímž byl terén srovnán. S dlážděním, z více méně plochých kamenů, jsme se setkali na několika dalších místech návrší. Nalezli jsme zde pozůstatky několika ohništ', avšak 
vzhledem k naprosté absenci jakýchkoliv nálezů, nejsme schopni říci, ani ze které doby pocházejí, nebot' mohou být i novověké.

K nejzajímavějším objektům, které jsme na návrší odkryli, patří zemnice či spíše zahloubený srub, otevřený k jihovýchodu (obr. 16:4). Objekt o rozměrech $4 \times 4 \mathrm{~m}$, na povrchu $5 \times 5 \mathrm{~m}$, se nacházel nad jihovýchodním svahem v nejužším místě návrší, $40 \mathrm{~m}$ od skály s věží. Již před výzkumem byla v tomto místě patrná výrazná terénní deprese. V bezprostřední blízkosti nad objektem procházela přístupová cesta, oddělená od jeho okraje jen kameny, z nichž některé se sesuly do objektu. Objekt byl vyhlouben ve skále a jeho tři stěny se svažovaly poměrně prŕkře. K jihovýchodu byl otevřen, takže terén jen mírně převyšoval úroveň podlahy. Svah před ním byl odtěžen, aby byl zajištěn dobrý výhled, a klesal až na hranu nad př́kopem.

V poměrně značné hloubce se objevila mohutná vrstva mazanice vyplňující celou spodní část objektu. Mazanicové bloky s otisky kủlů a vyhlazenými plochami ležely dosti zmateně přes sebe a jsou důkazem mohutné dřevěné konstrukce stropu, popřípadě i stěn. Pod mazanicí se zachovaly fošny až $2 \mathrm{~cm}$ silné. Na stavbu tedy byla použita jak kulatina, zřejmě na strop, tak fošny, na vydřevení stěn. Mohutná vrstva mazanice zůstala uchycena na severozápadním svahu objektu, kde dosahovala mocnosti $40 \mathrm{~cm}$. Při severovýchodní stěně jsme pod ní nalezli zbytky tunelové pícky, propálené do temně rudé barvy. Její odkrytí doprovázely nálezy značného množství zcela rozdrcených kostí a keramických nádob dokazující, že zánik objektu byl náhlý. Po odstranění přepálených kamenů a mazanice jsme dosáhli zčernalé podlahy s vrstvou uhlíků, či spíše sazí. V objektu byla nalezena petlice, nožík a hřeby. Rozdrcené keramické nádoby, jež v době zániku objektu stály u pícky, ukazují na razantní pád stropu, který je svou vahou zcela rozdrtil. Vzhledem k jeho poloze je funkce objektu jasná. Jeho úkolem bylo střežit jihovýchodní svah.

Na východním okraji tohoto objektu jsme nalezli v pásu nahromaděné kameny, zbytky nasucho kladené kamenné zídky, která stoupala po svahu vzhůru (obr. 16:5). Její délka byla 4,7 m. Na jejím konci na ni navazoval objekt, podobný objektu č. 2 . Jeho obvod vyznačovaly opět řady kamenů zhruba do plochy $3 \times 2 \mathrm{~m}$. Uvnitř se nacházely zbytky ohniště zabírajícího asi polovinu jeho výměry, po němž zůstala třiceticentimetrová vrstva mazanice (obr.16:6). Celý prostor byl opět zcela bez nálezů keramiky i kostí, takže nelze uvažovat o tom, že by se zde nacházela kuchyně, at' obránců, či oblehatelů. Dále k severovýchodu na stavbu navazoval kruhový zahloubený objekt o průměru 1,4 m. Byl zasypán rozměrnými kameny, jejichž páčení při vytahování bylo velmi obtížné (obr. 16:7). Přesto jsme ho vytěžili do hloubky 1,2 m, avšak dna jsme nedosáhli. Že byl objekt hlouben záměrně, je naprosto jisté. Mohlo jít o snahu zř́ídit zde cisternu, i když tomuto záměru př́liš neodpovídají zvětralé stěny. Ty byly také důvodem, proč jsme v dalším prohlubování nepokračovali.

Jižní stranu návrší ukončuje velký skalní výstup, jehož vnější strana je svislá a hladká. Také jeho horní plocha je srovnána a vnější okraj zvednutý (obr. 16:10). Podél vnitřní hrany jsme odkryli $25 \mathrm{~cm}$ široký a stejně hluboký žlab, který se podél skály stáčel k jihovýchodu a byl čelně ukončen kolmo zasekanou skálou. Snad se jedná o žlab pro založení srubové stěny nad tímto kamenem, ze kterého je jedinečný výhled. Z něho bylo možné dobře kontrolovat př́stupovou cestu, která přicházela po vrstevnici přímo proti němu a podél něj překonávala strmou stezkou poměrně značný výškový rozdíl na návrší (obr. 16:12). Ze žlabu pocházejí nálezy dvou šipek s tulejí a mince Vladislava Jagellonského, svědčící i o pozdějším zájmu o toto místo.

\section{Dřevohlinitá stěna (obr. 16:8)}

Na prudkém hliněném svahu, kudy i dnes vede podél zmíněné skály turistická cesta, se na povrchu občas objevovala doruda vypálená mazanice. Po odstranění 30 až $40 \mathrm{~cm}$ vrstvy zeminy se objevila po celém svahu. Mazanice před skálou dosahovala mocnosti $55 \mathrm{~cm}$ a směrem od skály klesala na $25 \mathrm{~cm}$, tedy nacházelo se jí zde značné množství. Jednalo se spíše o malé hrudky s kameny a místy i s keramikou. Byla vypálená do různých odstínů červené barvy až do cihlového zabarvení s otisky řezanky. Spolu s mazanicí se objevily i velmi zajímavé nálezy jako část 


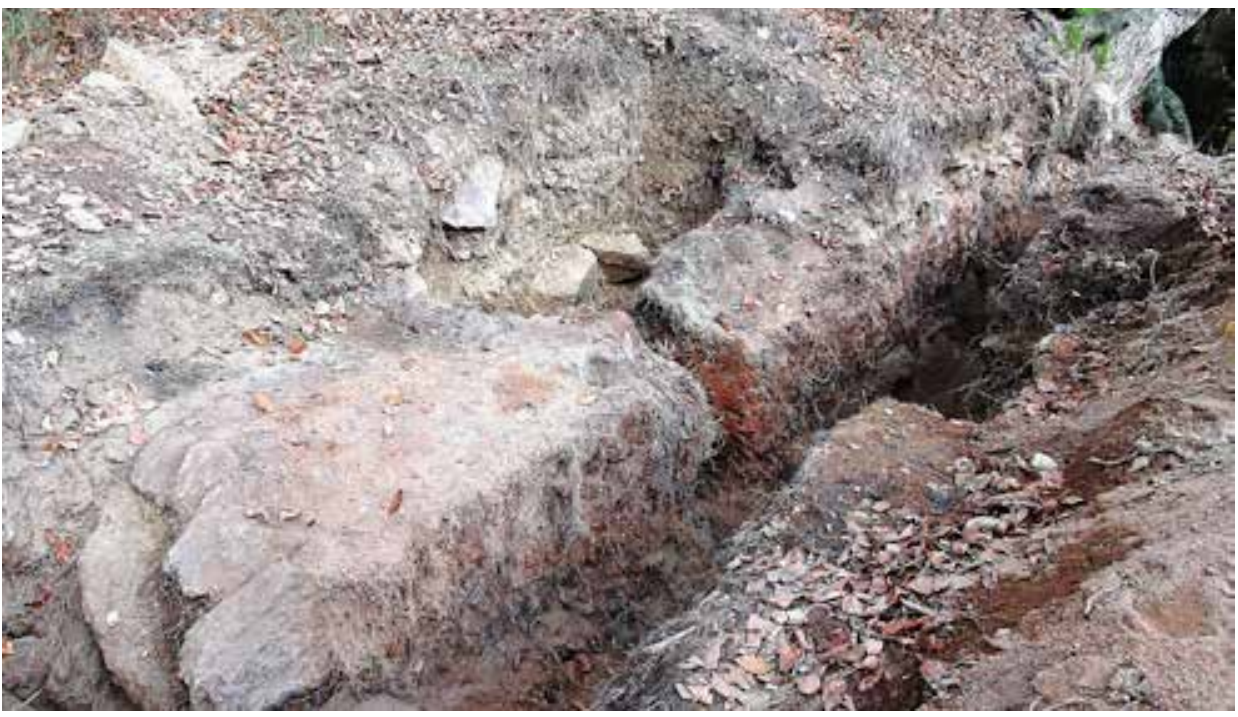

Obr. 18. Dřevohlinitá stěna ukončená velkými kameny navazovala na skálu zakončující na jihozápadě straně návrší (obr. 16:8), pohled od západu.

Abb. 18. Die von großen Steinen abgeschlossene Holz-Lehm-Wand schloss an den abschließenden Fels an der Südseite der Anhöhe an (Abb. 16:8), Blick von Westen.

loštického poháru, luxusní tenkostěnná keramika, keramika terakotové barvy, hrací kostka, ale především obrovské množství hřebů s křídlovou hlavicí. Jako doklad toho, že i toto místo bylo předmětem obléhání, jsme pod skálou nalezli dělovou kouli malé ráže a šipky. Ukázalo se, že mazanice pochází z rozpadu hliněné stěny, která nejdříve jen vyplňovala otvory mezi skalisky, ale dále stoupala na vrchol návrší až k ukončení mohutného př́íkopu a valu. Vzhledem ke značnému množství mazanice a nálezů je pravděpodobné, že se nad stěnou, na okraji návrší, nacházel srub, po kterém zůstaly pod skálou vrstvy spáleniště.

Oproti svislé skále jsme nalezli pozůstatky původní štětované cesty, která se obloukem dostávala na rampu a esovitě se stáčela na návrší (obr. 16:12). V tomto místě byl nad ní až půlmetrový zásyp, takže cesta stoupala původně do areálu pozvolněji, než je tomu dnes. Souběžně s ní jsme podél skály po svahu vzhůru položili sondu, která dosáhla hloubky 1,3 m. I zde v celé ploše leželo množství mazanice a černě zbarvené spálené vrstvy. V hloubce $80 \mathrm{~cm}$ pod povrchem jsme nalezli šipku, skobu a část podkovy. Zároveň jsme odkryli hliněnou stěnu navazující na skálu, jejíž funkcí bylo prodloužit ohrazení jižní strany od skály až k vnitřnímu př́ikopu a valu. Její stavbou zanikla př́istupová cesta na návrší (obr. 18).

Na velkou svislou skálu tvořící základ opevnění jižní strany navazovala menší. Mezi ní a dalším vystupujícím skaliskem byla $1,5 \mathrm{~m}$ široká mezera. Ta byla původně vyplněna hlínou, jejíž čelní strana byla na povrchu uhlazena do roviny se skalisky. Stěna dále pokračovala nad sousední, jen $40 \mathrm{~cm}$ vysokou skálu, kde tvořila její nadstavbu, a podél okraje návrší po svahu vzhůru již mimo skálu až na návrší. Její celková délka byla $7,7 \mathrm{~m}$ a dosahovala výše $1,2 \mathrm{~m}$. Z toho 70 až $80 \mathrm{~cm}$ bylo vysokým žárem vypáleno místy až do tvrdosti cihly. Horní část byla proložena plochými kameny a vypálena méně, takže jsme měli možnost v ní nalézt částečně ohořelé trámky. Na povrchu vypálené mazanice, na vnitřní straně stěny, se v jednom místě zachovaly zbytky trámu o průřezu $20 \times 20 \mathrm{~cm}$.

Stěna byla ukotvena ve žlabu podélně odtesaném ve skále. Na jihovýchodní straně navazovala na skálu, z vnitřní strany byla obložena velkými balvany, které zapíraly i její ukončení (obr. 18) a pokračovaly do pravého úhlu jako základ valu. Během postupného rozebírání stěny 
jsme zjistili, že při zemi byly podél ní uloženy z obou stran řady kamenů jako podklad pro vzájemně propojené trámy, na kterých byla stěna založena. Po stranách stěny se zachovaly otisky fošen, které byly umístěny nad trámy a mezi které byla hlína nabíjena. Ve výšce $60 \mathrm{~cm}$ byla stěna opět propojena dřevěným roštem, a to se opakovalo ve výšce $1,2 \mathrm{~m}$. V mezivrstvách byla pokládána dřeva výrazně tenčí, zdá se, že bylo využito i větví. Protože v posledních $50 \mathrm{~cm}$ se návrší od stěny odklánělo, byl meziprostor dosypán pískem a úroveň návrší byla srovnána s vrcholem stěny do roviny. Stěna tak vytvořila taras zakončující v návaznosti na skály jižní stranu návrší. Na vrchol stěny bylo uloženo několik vrstev nasucho kladených kamenů, které mohly vytvářet podklad pro předpokládanou srubovou stavbu. Mimo konstrukce dřevohlinité bašty tvořené dvěma souběžnými trámovými stěnami s hlinitopísčitou výplní tak máme doloženu další technologii stavby hliněné stěny se dřevěným roštem.

Před stěnou ležela celá řada trámů, které od ní různě vybíhaly. Velmi dobře dochovaný trám začínal na úrovni terénu $70 \mathrm{~cm}$ od paty stěny, $\mathrm{v} 90 \mathrm{~cm}$ se prudce ohýbal směrem dolů a končil $1,2 \mathrm{~m}$ od stěny. Ve vzdálenosti $1 \mathrm{~m}$ od ní se terén svažoval nejen $\mathrm{k}$ jihovýchodu ve směru původní cesty, ale i k jihozápadu do výrazného prŕíkopu. Nálezy dřev před stěnou mohou ukazovat na další obranný prvek, jakým byl například španělský jezdec. Značné množství kamenů ležících u paty stěny i před ní ukazuje na možnost jejího obložení nasucho kladenými kameny, které by ji činily obranyschopnější. Mezi kameny na povrchu stěny byl učiněn zajímavý nález drobného klíčku k visacímu zámku se zdobeným očkem.

Taras navazuje na val v místě, kde val oválně uzavírá $10 \mathrm{~m}$ široký příkop. Nalezli jsme zde udidlo, úlomek dlaždice a několik střípků. Dno prríkopu bylo v tomto místě vyloženo kameny. Jeho vnitřní strana byla zpevněna nasucho kladenou zídkou, vnější vymezují dva obrovské balvany ležící na svahu. Val je zde mohutný, směrem do druhého př́ikopu má výšku několika metrů a směrem k severozápadu se ještě zvyšuje. Př́ikopy byly bez nálezů.

Pod kolmou skálou jsme $\mathrm{v}$ místech př́stupové cesty a jejího stočení na rampu položili několik sond. Tam, kde skála tvořila povrch cesty, byla ukázkově zarovnána. Její šiř́ka byla dostačující, aby po ní projela dvoukolá kára. Pod cestou leží řada velkých balvanů, jež často mají pod sebou dutiny bez nálezů. V př́kopu i v okolí se nachází kusy skal odlámané patrně při jejich kopání. Je zajímavé, že př́íkop, který prot’al přístupovou cestu, byl zasypán okolním materiálem. Je otázkou, zda to lze přičíst na konto Klubu českých turistů, který zde zř́ídil více takových přechodů, aby umožnil snazší pohyb po zřícenině.

Výzkum pokračoval sondami v př́ikopu na jihovýchodní straně, kde byly nalezeny jen dva hřebíky. Zdá se, že dno př́ikopu mohlo být zahroceno, ale vzhledem k jeho nedokončení je těžké o tom spekulovat. Ve východní části příkopu pod věží nalezl „detektoráŕ“ celou napínací část kuše. Také sondy položené oběma hotovými příkopy na severozápadní straně byly negativní.

Funkci objektů nalezených na návrší lze vesměs spojit s existencí hradu. Naprosto jasná je interpretace dřevohlinité stěny uzavírající přístup na návrší, která pochází ze závěru existence hradu. Její charakter spolu s mohutnými prŕíkopy a valy u ní ukazuje na větší ambice při obraně tohoto místa.

Čtyři odkryté objekty umístěné téměř v řadě za sebou hovoří o stavební aktivitě, která zde v určité době probíhala s určitým záměrem. Jistá je funkce zahloubeného srubu stř̌ežícího jihovýchodní svah. Mimo nálezů z něho však jakékoliv další artefakty postrádáme. Obě lehké stavby s ohništi lze vysvětlit jako místa, kde se strážci mohli ohřívat, a také pokus o hloubení cisterny můžeme spojit s jejich aktivitami. Vysvětlení vzniku př́ikopů a valů je však složitější a lze předpokládat několik řešení. Přri výzkumu nedokončeného hradu na kopci Čepička jsme zjistili postup prací při budování hradu. Nejdříve byl srovnán vrchol a kolem něho vyhloubeny prŕíkopy a navršeny valy. Teprve potom docházelo k další výstavbě (Belcredi 1990, 116).

Prvním řešením tedy je, že původním záměrem bylo hrad založit na tomto návrší. Proto bylo srovnáno a začalo se $\mathrm{s}$ budováním prríkopů a valů. Ukazuje na to především dobudování dvojitého prríkopu a valů směrem $\mathrm{k}$ hradu, odkud bylo návrší nejzranitelnější, což by v prŕípadě již dokončeného hradu bylo zbytečné. Spíše by byly budovány na opačné straně. Během stavby však někdo přišel se zcela nekonvenčním nápadem, že mnohem jednodušší a účelnější bude hrad 
vybudovat mezi skalami. Úplně tak sice změnil koncepci stavby, ale hrad se na svou dobu stal prakticky nedobytným.

Druhým řešením je, že úpravy souvisí s příchodem polního vojska, které zde budovalo svůj tábor. Obyvatelé tábora by však návrší jistě opevňovali především z vnější strany a zůstalo by nám po nich mnoho svědectví v podobě nálezů, ale nic takového jsme nenalezli.

Třetí možností je, že návrší bylo srovnáno již dříve a valy s př́ikopy vybudovali oblehatelé, nebot' na návrší si po jeho obsazení zř́ídili hlavní tábor. Ale i oni by po sobě zanechali výrazné artefakty, které jsme nenalezli, a obléhání by v takovém případě muselo trvat týdny, aby př́ikopy a valy vybudovali.

Nejpravděpodobnější se tak jeví varianta první s tím, že v následujících desetiletích sloužilo návrší $\mathrm{k}$ zabezpečení jihovýchodní přístupové cesty z údolí a na jejím povrchu nedocházelo k žádným dalším aktivitám. Dřevohlinitá stěna, opevňující jižní konec, s největší pravděpodobností souvisí až s budováním předsunutých opevnění v závěru existence hradu.

Kovářský areál (obr. 1:12 a obr. 19)

Jihozápadně od hradu klesá 220 m dlouhý svah podél hradu od opevněného návrší ke zlomu terénu na severozápadní straně. Zlom se táhne pod hradem v šířce $115 \mathrm{~m}$. Od vnějšího opevnění před hradem je hrana svahu vzdálena 27 až $123 \mathrm{~m}$. V horní části svahu byly kameny v pozdějších stoletích nakupeny do několika míst, zřejmě ve snaze vytvořit zde pole či spíše pastviny. Ve střední části, na úrovni předsunutého opevnění, kamenů výrazně ubývá, naopak severozápadní část pod hradem je jimi doslova zaplavena, a ještě dnes je obtížné se přes ně bez problémů $\mathrm{k}$ hradu dostat. Protože jsme předpokládali, že se v této ploše mohou nacházet výsledky lidské činnosti, nechali jsme ji geofyzikálně proměřit a nemýlili jsme se. Jihozápadně od druhého valu, nad původní cestou, se v ploše $15 \times 20$ m objevila řada zajímavých objektů.

Na jihozápadní straně je ve svahu vymezoval čtverec 5:19. Jeho východní část byla souvisle vydlážděna drobnými kameny, na nichž spočívala černá spálená vrstva, místy značné mocnosti (obr. 19:721). Tam, kde dlažbu přečnívala, spočívala přímo na žlutě zbarveném podloží. Velikost této plochy byla $3,5 \times 2,5 \mathrm{~m}$ a přesahovala $1 \mathrm{~m}$ do sousedních čtverců. Obsahovala nálezy strusky, několika střepů, hřebíky, ale také nárazem deformovanou olověnou kulku. Objekt pokračoval dále severním směrem do čtverce $5 / 18$, kde končil v místě kumulace množství kamenů (objekt 722).

V bodě $5 / 18$ jsme odkryli velké nahromadění kamenů, které vyplňovalo jámu o průměru 2,4 m (obr. 19:723). Kameny pocházely z nasucho kladené zdi, která stála kolmo k jihozápadnímu okraji jámy. Od počátku se v jámě objevovaly zajímavé nálezy. Na povrchu značné množství železité strusky o rozměrech až $18 \times 20 \mathrm{~cm}$, množství keramiky, ale také úlomky dlaždiček a kovové předměty jako např́íklad kování a tři šipky. V hloubce $40 \mathrm{~cm}$ se objevilo několik silně zkorodovaných želez, ale jáma pokračovala hlouběji. Zešikmené stěny byly místy zpevněny kameny. Na jihovýchodní straně se v hloubce $70 \mathrm{~cm}$ pod povrchem objevila spálená vrstva dřev s keramikou, celá malá dlaždička, polovina malé podkovy, větší klínec a další drobné kovy. Po začistění se ukázala šedě zbarvená vrstva podlahy zasahující pod jihovýchodní a částečně i severozápadní zborcené stěny. Konečná hloubka objektu dosáhla $80 \mathrm{~cm}$. Na dně jámy, již ve žlutě zbarvené hlíně, jsme nalezli několik kovových předmětů - neuzavřenou trubku o délce $12,5 \mathrm{~cm}$, oko řetězu o průměru $5 \mathrm{~cm}$ a další deformované předměty. V severozápadní části se na podlaze objevil masivní kus $(5 \times 5 \times 5 \mathrm{~cm})$ velkého železa, kovadlina se zarážkou. Konečný rozměr jámy při dně činil $1,7 \times 1,4 \mathrm{~m}$, stěny byly zešikmené, severovýchodní byla zpevněna kameny. Vstupovalo se do ní od severozápadu nejméně $51 \mathrm{~cm}$ širokým vstupem, pod nímž se zachoval černě zbarvený schod o šířce $40 \mathrm{~cm}$, vysoký $33 \mathrm{~cm}$. V objektu jsme nenalezli otopné zařízení. Je jisté, že k zasypání objektu došlo v několika fázích, nejspíše ještě za doby existence hradu. O tom svědčí množství nálezů, které se dostalo mezi vrstvy zásypu, a nálezy na jeho povrchu, pocházející z doby zániku hradu. 


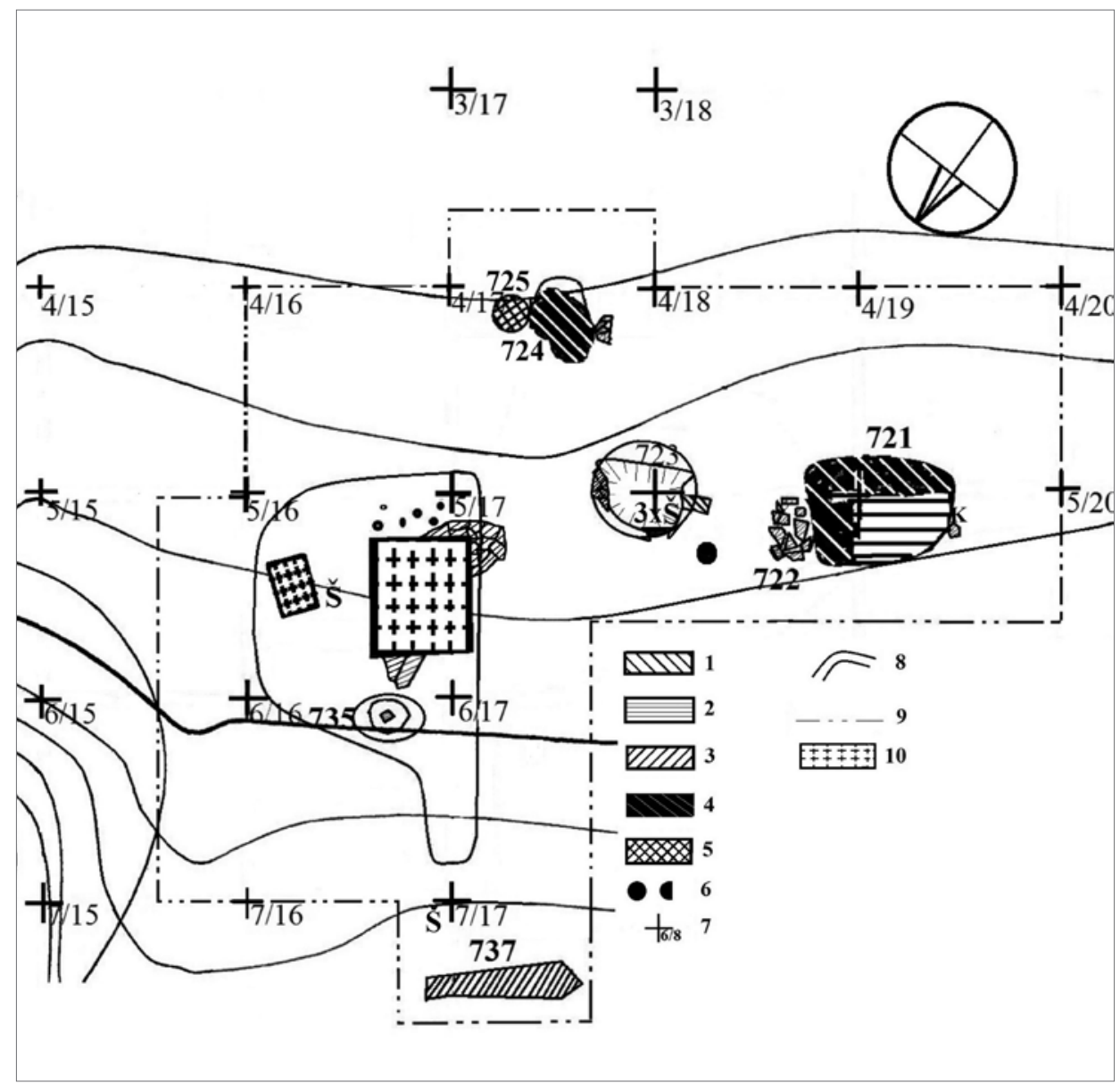

Obr. 19. Půdorysné zobrazení kovářského areálu s vyznačením objektů a některých nálezů (obr. 1:12). 1 - zdivo, 2 - dlažba, 3 - kameny, 4 - spáleniště, 5 - výhně a ohniště, 6 - dělové koule a jejich části, 7 - body čtvercové pětimetrové sítě, 8 - vrstevnice, 9 - výkopové hrany, 10 - úložiště strusky. Nálezy: Š - šipky, K - olověné projektily. Objekty: 721 - dlažba se spáleništěm, 722 - nahromadění kamenů, 723 - zahloubený objekt, 724 - spáleniště, 725 - ohniště, 735 - objekt se vztyčeným kamenem, 737 - kamenný taras. Nálezy: $\check{S}$ - šipky, K - olověné projektily.

Abb. 19. Grundrissdarstellung des Schmiedeareals mit Kennzeichnung der Objekte und einiger Fundstellen (Abb. 1:12). 1 - Mauerwerk, 2 - Steinplattenboden, 3 - Steine, 4 - Brandstätte, 5 - Esse und Feuerstelle, 6 - Kanonenkugeln und ihre Teile, 7 - Punkte des Fünf-Meter-Rasters, 8 - Höchenschichtlinie, 9 - Ausgrabungsrand, 10 - Schlackenlagerplatz. Funde: $\check{S}$ - Pfeile, K - Bleiprojektile. Objekte: 721 - Steinplattenboden mit Brandstätte, 722 - Ansammlung von Steinen, 723 - eingetieftes Objekt, 724 - Brandstätte, 725 - Feuerstelle, 735 - Objekt mit aufgerichtetem Stein, 737 - Steinterrasse. Funde:

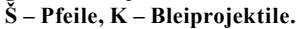

Východně od této jámy jsme ve čtverci $4 / 17$ opět narazili na vrstvu černého spáleniště velikosti 1,8 × 1,5 m, tentokráte o mocnosti $10 \mathrm{~cm}$ (objekt 724). Obsahovala bronzovou obdélnou přezku, válečkový zámek, půlku podkovy, střepy a kousky dlaždiček. Jeho severozápadní a jihovýchodní okraje byly barevně velmi dobře vymezeny, na severovýchodě se objevily též stopy po vypálené mazanici. Pod spáleništěm se ukázala žárem začervenalá podlaha a mísovitě zahloubené, dobře dochované kruhové ohniště o průměru $50 \mathrm{~cm}$ (objekt 725). Ve výběžku směrem k jámě bylo kumulováno několik velkých kamenů. Rozptyl spáleniště zasahoval až do čtverce 3/17, kde jsme v hloubce $50 \mathrm{~cm}$ pod povrchem nalezli střepy, úlomek cihly, okraj kachle a hřeby. 
Další zajímavé nálezy nás očekávaly ve čtverci 5/16. Ihned pod povrchem se objevilo neuvěřitelné množství strusky v podobě klasických kovářských buchet, okuje, množství keramických střepů, úlomky různých dlaždiček, ale hlavně kovy. Mimo množství hřebů to byly dvě části podkovy, ostruha, bronzový háček, nůž, udidlo, šipka, a úlomek skleněné číše. Do jihovýchodního rohu čtverce 5/16 se koncentrovaly nálezy střepů. Tam vystupoval okraj skály, který byl zatesán do žlabu. Na severní straně byla hromada strusky obložena kameny v ploše $1,5 \times 1 \mathrm{~m}$ a na opačné $\mathrm{v}$ ploše $3 \times 2,5 \mathrm{~m}$. Bylo sem deponováno mnoho kilogramů kovářské strusky, jak to známe např́íklad z deponie u kovárny v ZSV Bystřeci (Belcredi 2006, 237 - obr. 177). Po začistění plochy se na rostlém terénu objevila řada zahloubených objektů. Na jihovýchodní straně byly vyplněny kameny a vápnem, na opačné bylo do jam vloženo několik jednotlivých velkých kamenů. $Z$ jedné větší jámy vyčníval kámen postavený na výšku (objekt 735 ). Na dně byl podložen dalším a několik se jich nacházelo i v zásypu. Výplň tvořila jílovopísčitá, velmi tvrdá zemina. Kámen musel z jámy původně výrazně vyčnívat, nebot' i když jsme ho nalezli již hodně nahnutý, stále přesahoval okraj objektu. Jeho výška byla 80 a průměr $37 \mathrm{~cm}$. Vypáčit podkladní kámen na dně jámy znamenalo odstranit některé kameny po stranách, které ho překrývaly. Na dně jáma měřila $100 \times 80 \mathrm{~cm}$, při povrchu $1,9 \times 1,33 \mathrm{~m}$ a hluboká byla $60 \mathrm{~cm}$. Byla bez nálezů, na rozdíl od vrstev nad ní. Je podobná jámě v sousedním čtverci, z níž však pochází množství nálezů.

Nedaleko původní přístupové komunikace ke hradu jsme v několika čtvercích vedle sebe odkryli poměrně rozsáhlou pracovní plochu velikosti $15 \times 12 \mathrm{~m}$, zasazenou terasovitě do svahu. O její funkci jasně vypovídá nález okují a velkého množství strusky, která byla soustředěna nejen do dvou velkých hromad, ale rozptýlena po celé ploše a po svahu se dostala až desítky metrů daleko. Ta, spolu s dalšími indiciemi, hovoří jasně o tom, že máme před sebou bohužel zplanýrovaný kovářský areál. Záměrné zaházení zahloubených objektů kameny a dalším materiálem a nálezy militarií na jejich povrchu jasně ř́íkají, že k zániku areálu došlo ještě v průběhu existence hradu. Pozůstatkem výhní jsou propálené kameny, zemina a vrstvy mazanice. Zachovalo se pouze do země zahloubené kruhové ohniště, které též mohlo sloužit kovářským účelům. Řada mělkých zahloubených objektů podsypaných kameny mohla sloužit k postavení špalků a džberů $\mathrm{s}$ vodou a dvě dlážděné plochy překryté vrstvami spáleniště $\mathrm{s}$ množstvím hřebů mohou být pozůstatky lehkých dřevěných př́stř̌ešků nad výhněmi. Mezi nimi je propálená zemina a po celé ploše množství často rozměrných kamenů, kterými byly zaházeny též všechny zahloubené objekty. Funkci kovářské dílny potvrzují i nálezy poškozených velkých předmětů určených k překování a malá kovadlina. Existenci uzavřené stavby dokládá visací zámek. Zajímavý je nález poměrně značného počtu dlaždiček pocházejících skoro ze všech čtverců. Snad jimi byly obloženy výhně, protože kryté prostory měly dláždění z drobných kamenů. Také keramiky bylo nalezeno značné množství, proto zaráží naprostá absence kostí. Na zplanýrovaném povrchu jsme nalezli doklady závěrečného boje v podobě olověné kulky, čtyř šipek s tulejí a dělové koule.

Otázkou zůstává, čemu sloužil vertikálně zasazený kámen. Podobně instalované kameny většinou sloužily jako orientační body nebo označovaly nějak významné místo. Zde stojí nad skládkami strusky, což asi nebude pravý důvod jeho umístění. Stejně problematická je funkce velké jámy, ze které se mohlo obsluhovat nějaké zařízení kovárny.

Bude třeba ještě podrobně vyhodnotit keramické nálezy, které z celé lokality převážně ještě nejsou laboratorně zpracovány. Nálezy strusky hovoří jasně o značném provozu dílny, jejíž náplní jistě byla jak oprava nářadí, jeho vykovávání, tak i výroba nového z poškozených kusů. Činnost kovárny mohla být spojena již s počátkem hradu a přetrvat i do pozdější doby, nebot' tu byla nezbytně nutná a kovárnu v pravém smyslu slova jsme na hradě ani před ním nenalezli. Místo může být poznamenáno též intenzivním lesním hospodařením, provozovaným zde od druhé poloviny 18 . století.

Hroudy strusky se po svahu dostaly až k hranici čtverců 7/16 až 17. V nich se objevila navážka, s množstvím nálezů, upravující terén. K nejzajímavějším nálezům patří úlomek nožičky a další úlomky zřejmě plastiky s neidentifikovatelným zbytkem reliéfu kruhové výseče. Nalezli jsme zde i šipku s trnem či velmi malou podkovu s hřeby. Ve vzdálenosti $2,5 \mathrm{~m}$ od jihovýchodního okraje čtverce 7/16 byla navážka ohraničena vrstvou kamenů, které pokračovaly do 
sousedního čtverce 7/17. Tam vymezovaly okraj prudšího svahu a na opačné straně se ve čtverci 7/14 dostaly až k okraji svahu nad původní přístupovou komunikací. Keramické střepy byly splavovány po poměrně prudkém svahu, nebot' jsme je nalezli i v dalších čtvercích, které jinak byly naprosto sterilní.

Po svahu níže již byla jen vrstva žlutohnědé zeminy. Ve čtverci 8/16 jsme prot’ali původní prŕstupovou cestu, která zasahovala i do čtverce $8 / 17$ (obr. 1:15). Ta byla v celé šíři dlážděna drobnými i většími plochými kameny o rozměrech $20 \times 20 \mathrm{~cm}$ a k tomuto účelu byly využity i velké hroudy strusky. V tělese cesty i na jejím povrchu se nacházelo též větší množství keramiky, drobných kovových předmětů, především hřebů, ale i šipka a koňské zuby. Od severozápadu je stále ještě patrná mez, která cestu vymezovala. Pod ní byla plocha již bez nálezů, jen s jednotlivě rozházenými většími či menšími kameny.

Předsunuté opevnění před bránou (obr. 1:13 a obr. 20)

U nově budovaných opevnění husitské doby byl velký důraz kladen na kontrolu přístupové komunikace. Byla budována tak, aby ji bylo možno sledovat v co nejdelším úseku a k tomuto účelu vznikala předsunutá opevnění. $Z$ nich byl příchozí plně pod kontrolou obránců. V případě Skal mohl být ostřelován ze zahloubených srubů nad cestou ještě dříve, než samotný hrad uzřel. A když ho spatřil, ocitl se v dostřelu obránců $\mathrm{z}$ dalšího opevnění.

Ve vzdálenosti $20 \mathrm{~m}$ od brány prvního předhradí se nachází výrazná terénní vlna. Že se jedná o strategické místo, pochopili i obránci hradu. Proto na něj v řadě za sebou, od severu k jihu, umístili několik obrovských balvanů začínajících ve čtverci $9 / 15$ a pokračujících až do čtverce 11/12. Ve čtverci 11/13 nás upoutalo navršení zeminy mezi dvěma $\mathrm{z}$ těchto kamenů, za kterým se nacházela rovná plocha (obr. 20:799). Jednalo se o zbytek valu navršeného z hlíny a kolem něho se objevilo množství kostí, keramických úlomků, všudypřítomné hřeby, a projektil $\mathrm{v}$ podobě válečku. Rovná plocha za ním zasahovala $5 \mathrm{~m}$ za oba kameny. Ze souvislostí vyplynulo, že se jedná o palebné postavení oblehatelů, tentokrát jedno z nejdůležitějších. Z tohoto místa totiž bylo možné ostřelovat dřevohlinitou baštu předbraní.

K tomuto závěru jsme dospěli tak, že jsme označili místa nálezu dělových koulí a zjistili, že jedině z tohoto místa je bylo možné spatřit, a také je $\mathrm{k}$ tomuto účelu nejvhodnější. Postavení bylo $\mathrm{z}$ boků kryto velkými balvany a $\mathrm{k}$ hradu valem z navršené zeminy. Terén byl srovnán vrstvou o mocnosti až $50 \mathrm{~cm}$ materiálem ze smetiště nacházejícího se na opačné straně severního kamene a podložen několika rozměrnými plochými kameny. Jeho existence nás přivedla na další objekt, nacházející se za tímto kamenem. Jako zajímavost je možné uvést, že $70 \mathrm{~cm}$ pod úrovní terénu jsme při severozápadním okraji jižního balvanu nalezli hroudu strusky o velikosti $20 \times 20 \mathrm{~cm}$.

Převážnou část čtverce 11/12 zabírá kámen velikosti $2,4 \times 4,3 \mathrm{~m}$, dosahující obdobně jako ostatní výšky až 1,6m (obr. 20). Po obvodu čtverce se nacházelo množství hřebů a úlomků keramiky a na severovýchodní straně větší počet zajímavých kovových předmětů jako postranice koňského udidla, celé tyčinkové udidlo, ostruha s kolečkem, čepel nože, oko řetězu, přezka podbřišníku, válečkový projektil, také značné množství kostí a keramiky, z níž zaujal velký střep zdobený po celé výduti radélkem. Celý objekt byl doslova napěchován nálezy. Středem balvanu ve čtverci $11 / 12$ jde $17 \mathrm{~cm}$ široká a $45 \mathrm{~cm}$ hluboká prasklina, která ho rozděluje na dvě části. Zapadly do ní úlomky dlaždiček a cihel. Za ním jsme, kromě obvyklých kostí a keramiky, nalezli též dvojhrotou šipku, jedinou na lokalitě. Jihozápadně od něj, mezi dvěma balvany, ležela na šedě zbarvené podlaze v ploše $4 \times 4$ m žlutá jílová vrstva o mocnosti $30 \mathrm{~cm}$. Od východní části čtverce 11/12 vystupovalo na povrch kamenné pole tvořené neuspořádaně ležícími kameny větších rozměrů a zasahovalo až do čtverce 10/12. Jelikož jsou jeho okraje nepravidelné, můžeme původní rozsah pouze odhadovat na $8 \times 7 \mathrm{~m}$.

Je pravděpodobné, že se zde nacházel obranný srub, zasazený mezi dva velké kameny. Jílová vrstva nevypálené mazanice spadlá na dlažbu zřejmě pochází z jeho stropu či stěn. Jihozápadní a jihovýchodní prostor kolem stavby byl zpevněn kameny. Vstoupil-li někdo na svah 


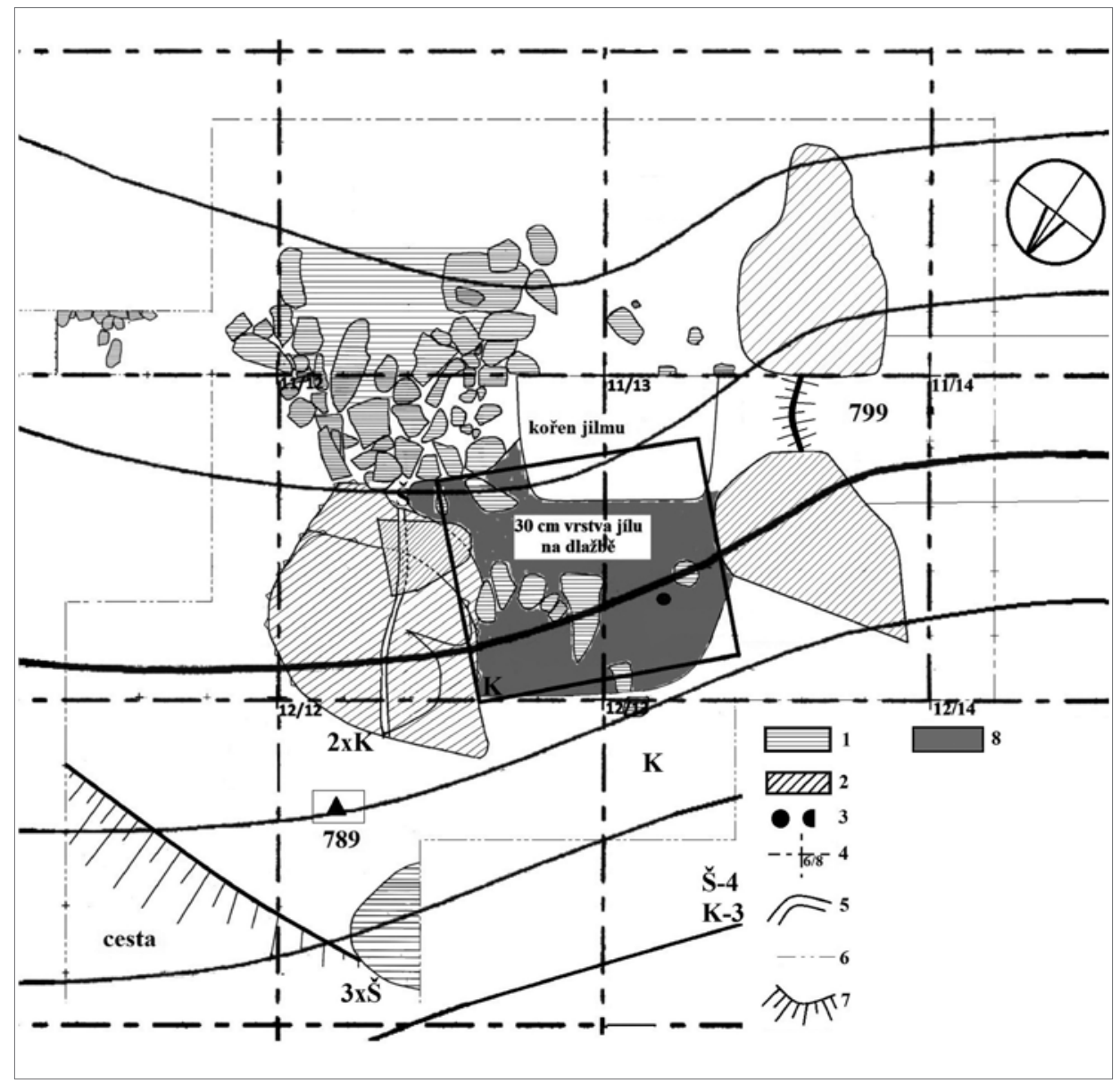

Obr. 20. Půdorysné zobrazení předsunutého opevnění před bránou do prvního předhradí (obr. 1:13). 1 - dlažba a jednotlivé kameny, 2 - oddělené bloky skal, 3 - dělové koule a jejich části, 4 - čtvercová pětimetrová sít', 5 - vrstevnice, 6 - výkopové hrany, 7 - sklon terénu, 8 - nevypálená mazanice na dlažbě. Objekty: 789 - hraněný kámen, 799 - srovnaná plocha obléhacího postavení. Černé orámovaní - pravděpodobná poloha obranného postavení. Nálezy: ̌̌ - šipky, K - olověné projektily. Abb. 20. Grundrissdarstellung der vorgezogenen Befestigung vor dem Tor zur ersten Vorburg (Abb. 1:13). 1 - Steinplattenboden und einzelne Steine, 2 - separate Felsblöcke, 3 - Kanonenkugeln und ihre Teile, 4 - Fünf-Meter-Raster, 5 - Höhenschichtlinie, 6 - Ausgrabungsrand, 7 - Geländeneigung, 8 - nicht verbrannter Lehmbewurf auf dem Steinplattenboden. Objekte: 789 - abgekanteter Stein, 799 - eingeebnete Fläche der Verteidigungsstellung. Schwarz gerahmt - wahrscheinliche Lage der Verteidigungsstellung. Pfunde: $\check{S}$ - Pfeile, K - Bleiprojektile.

před hradem, stanul ve vzdálenosti $100 \mathrm{~m}$ přímo proti němu. Přicházel-li od jihozápadu, ocitl se nejdříve v terénní depresi, z níž mu ve výhledu na předsunuté opevnění bránil zvýšený terén vystupující po svahu od jihu, na jehož konci stál právě tento srub. Teprve od něj se otevřel pohled na první předhradí.

Pod ním vedla čtverci 12/11 až 12/12 nová přístupová cesta. Její severní hrana byla zpevněna kameny nacházejícími se těsně pod povrchem. V místě nejvyššího svahu dosahovala jejich šiřka $1 \mathrm{~m}$. Cesta byla necelé $2 \mathrm{~m}$ široká a přecházela $\mathrm{z}$ mírného svahu blíže u hradu v prudší klesání ve čtverci 12/12. Místo se vyznačovalo poměrně značným počtem nálezů - nalezli jsme visací zámek, udidlo, měděné plíšky, část jedné a druhá celá podkova, nůž, také nálezy dvou 


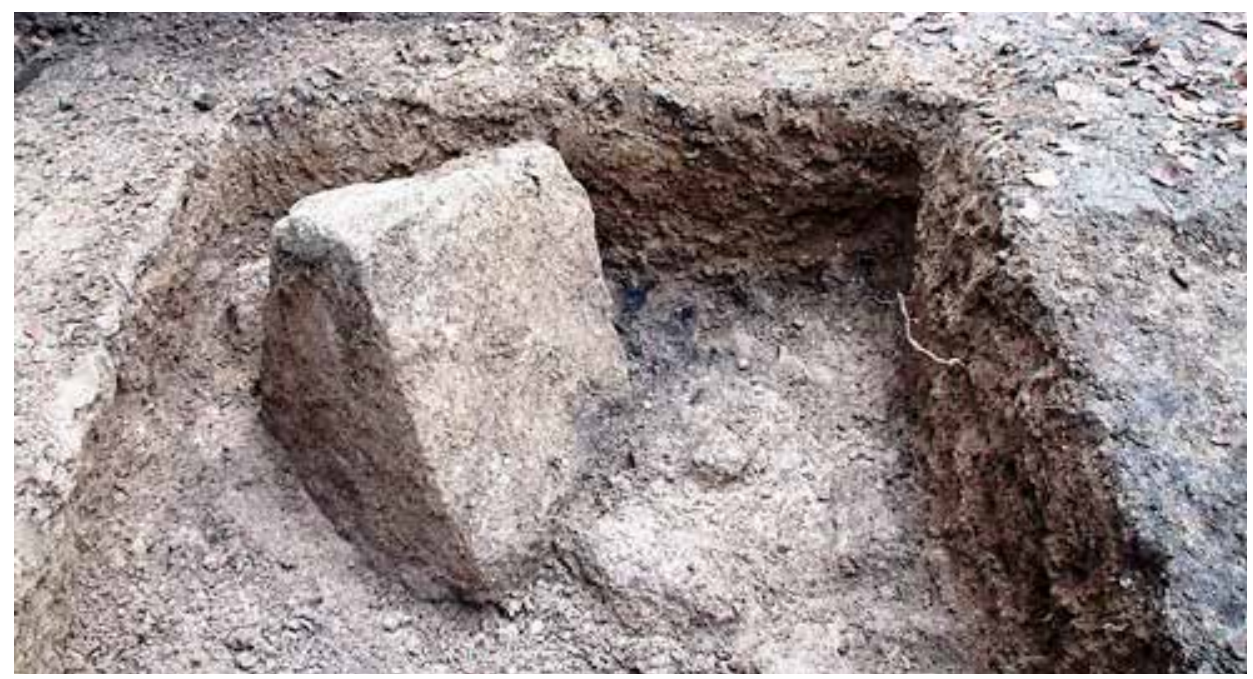

Obr. 21. Trojúhelníkový hraněný kámen situovaný k cestě před obranné postavení (obr. 20:789), pohled od západu. Abb. 21. Dreieckiger, abgekanteter Stein mit Lage zum Weg vor der Verteidigungsstellung (Abb. 20:789), Blick von Westen.

válečkových projektilů a množství různě velkých hřebů. Otázkou je použití množství dlaždiček, které se nacházejí téměř všude, a to jak v kovářském areálu, tak i zde.

Svah vyzníval směrem k 8 m vzdálené výhni na barevné kovy a končil 4,3 m od ní. Ze čtverce 10/11 jsme položili směrem k ní sondu, čímž jsme uzavřeli pomyslný kruh výzkumů před hradem. Mimo zde všudypřítomných kostí, keramiky a hřebů jsme nalezli také dva nože. Další nálezy pocházejí ze čtverce 12/13, kde se již kameny nevyskytovaly, nebot' skončily přesně na jeho jihovýchodním okraji. V třiceticentimetrové vrstvě tmavé hlíny ležící na vrstvě jílu, jejíž mocnost po svahu dolů výrazně klesá, byly nalezeny přezka s háčkem, šipka, kulka, článek řetězu, bronzová struska, dva měděné pásky, celá podkova, šídlo, držadlo hřebla, hřebíky, dva velké hřeby a půlka velké dlaždice. Jelikož terén je zde velmi členitý, ke srovnání cesty bylo třeba použít až $70 \mathrm{~cm}$ mocnou navážku jílovité hmoty v šířce $2,6 \mathrm{~m}$, do které byly zabudovány i velké kameny. Na povrchu i za hranou ve svahu se opět nacházelo množství nálezů jako tři groše, falzum mince, dvě šipky s tulejí a jedna s trnem, trn s kruhem, ostruha a jedna a půl podkovy. Severozápadním směrem po svahu dolů se stále vyskytovalo velké množství keramiky, často velkých a silnostěnných výdutí a také kosti.

Od krajního velkého kamene k cestě se nacházela plocha navršené čisté zeminy. Terén zde tvoří ohyb, za kterým klesá k cestě v prudším svahu. Právě na hraně tohoto svahu se nacházel objekt, ze kterého vyčníval vrchol úzkého kamene (obr. 20:789 a 21). Uvnitř objektu se nacházel šikmo ležící kámen trojúhelníkovitého tvaru o rozměrech $70 \times 80 \times 40 \mathrm{~cm}$ s naprosto rovnými stranami. Je pravděpodobné, že původně vyčníval na povrch, stejně jako kámen u strusky. Tento je však mnohem pravidelnější. U jeho paty se do vzdálenosti $25 \mathrm{~cm}$ podélně táhla černá vrstva. Kolem něho je jinak naprosto čistá zemina bez nálezů; jeho funkce nám zatím uniká. Snad mohl být bodem na zamíření pušky z dřevohlinité bašty směrem na přístupovou cestu.

Stavba postavená na tomto místě byla dalším významným stanovištěm kontrolujícím a zjevně také bránícím př́ístup k hradu, o které byl sveden tuhý boj. Svědčí o tom nálezy množství militarií včetně olověných projektilů, šipek, a především dělová koule malé ráže, které stavba s největší pravděpodobností neodolala a bez požáru se zř́ítila. V sousedství vytvořené smetiště obsahující značné množství kostí a keramiky dokládá na tomto místě intenzivní život a nepřeberné počty hřebů svědčí o prrítomnosti dřevěné stavby. Teprve po jejím zničení bylo možné 
tuto strategickou pozici ovládnout a přesunout na ni dělo, které přímo ostřelovalo dřevohlinitou baštu. Na tu však jeden výstřel nestačil.

Předsunuté zahloubené sruby (obr. 1:1401, 1402, 1404, 1405 a 1406)

Př́stupová komunikace $\mathrm{k}$ hradu Skály byla zabezpečena řadou předsunutých zahloubených srubů, rozmístěných v mírném ohybu podél terénního zlomu táhnoucího se od severovýchodních skal šikmo k západu až k místu, kde cesta ve vzdálenosti 140 m od brány prvního předhradí vystupovala na pláň před hradem (obr. 1). V době odlesnění okolí hradu byl ze zlomu viditelný její značný úsek postupně se k němu přibližující. Ke kontrole cesty byly na hraně svahu zřízeny dva zahloubené sruby, další tři byly umístěny přímo u výstupu cesty. Obyvatelé hradu tak měli pod kontrolou každého, kdo se na této cestě objevil, a to i když nemíŕil na hrad. Cesta k hradu byla totiž odbočkou z komunikace, která vedla dále přes kopec Rabuňku do Věcova. Souběžné hluboké úvozy a jejich dláždění v kopci naznačují, že mohla být dosti frekventovaná. Také v nich jsme nalezli různé středověké kovové předměty.

Objekt 1401 (obr. 22:1401)

Jáma se nachází v př́mce pod bránou na val, ve vzdálenosti $65 \mathrm{~m}$ od ní. Jedná se o oválný objekt velikosti 3,9 × 3,3 m, zahloubený $1,3 \mathrm{~m}$. Je orientován podélně se svahem, přímo na jeho hraně. Západní strana se od povrchu terénu pozvolna svažuje $v$ délce $2,05 \mathrm{~m}$ a šířce $1,8 \mathrm{~m}$, kde se rozšiřuje. Protější svah je strmý, vysoký $1,2 \mathrm{~m}$. V severovýchodním rohu je mezera, jejíž šiřku vzhledem ke vzrostlému stromu není možné zjistit. Zbylé dvě strany jsou vysoké $1 \mathrm{~m}$. Na svazích jámy, především na těch strmějších, leží poměrně značné množství i velkých kamenů, které byly původně zřejmě umístěny po jejím obvodu. Dostaly se tak do objektu druhotně. Hlína z jámy byla navršena na hranu svahu, kde z ní byl podél celého objektu vytvořen výrazný val. Č́st je vyházena též na stranu $\mathrm{k}$ hradu. Ze svahu pod objektem vyčnívá menší skalní blok, o který se hlína valu opřela. Celý objekt zabírá prostor $6 \times 4,2 \mathrm{~m}$. Před valem byly nalezeny čtyři šipky a půlka podkovy. Zřejmě se jedná o obranný srub, avšak výrazná rampa ze vzdálenější strany hradu napovídá, že ho mohli využít i oblehatelé.

Objekt 1402 (obr. 22:1402)

Po svahu, 32 m od objektu 1401, se nachází druhý zahloubený objekt, který se od prvního liší, nebot' je čtvercového půdorysu se zaoblenými rohy a většina hlíny je vyházena nad objekt. Jen menší množství tvoří nevelký val před ním. Jeho vnitřní prostor má velikost $2,4 \times 2,6 \mathrm{~m}$. Stěny byly zřejmě původně zpevněny kameny, $\mathrm{z}$ nichž podobně jako $\mathrm{v}$ prvém př́ípadě některé dosahují značných rozměrů. Strany jsou pravidelné, bez výrazného nástupního svahu, i když západní je opět delší - $1,8 \mathrm{~m}$, kdežto východní měří jen $60 \mathrm{~cm}$. Výška dvou zbývajících stran je $50 \mathrm{~cm}$. Celý objekt, včetně valů a hromad zabírá prostor téměř $5 \times 5 \mathrm{~m}$. U objektu byly nalezeny části dvou podkov a hřebík.

Objekt 1404 (obr. 22:1404)

Třetí, nejlépe dochovaný objekt se nachází o dalších 21 m níže. Je situován jen $1,1 \mathrm{~m}$ východně od př́stupové komunikace, v místě, kde z hlubokého úvozu vystupuje na povrch. Na rozdíl od prvních dvou objektů, které můžeme považovat za obranné sruby, tento vyhlíží spíše jako zákop. Uvnitř měří jen $1,8 \times 0,8 \mathrm{~m}$, stěny se svažují do hloubky $1,05 \mathrm{~m}$. Delší stranou je orientován po vrstevnici. Navršení valů byla věnována značná pozornost. Bylo $\mathrm{k}$ tomu použito velkého množství hlíny, rozhodně více, než bylo možné získat výkopem jámy. V délce $3,7 \mathrm{~m}$ byl před objektem ve směru prrístupu nasypán mocný val pravidelného oválného tvaru, široký $1,8 \mathrm{~m}$. Zbytek hlíny byl rovnoměrně rozprostřen kolem zbylých stran. Na dně objektu se nacházela černá vrstva se třemi střepy z jedné nádoby a zvlněný střep skla. 


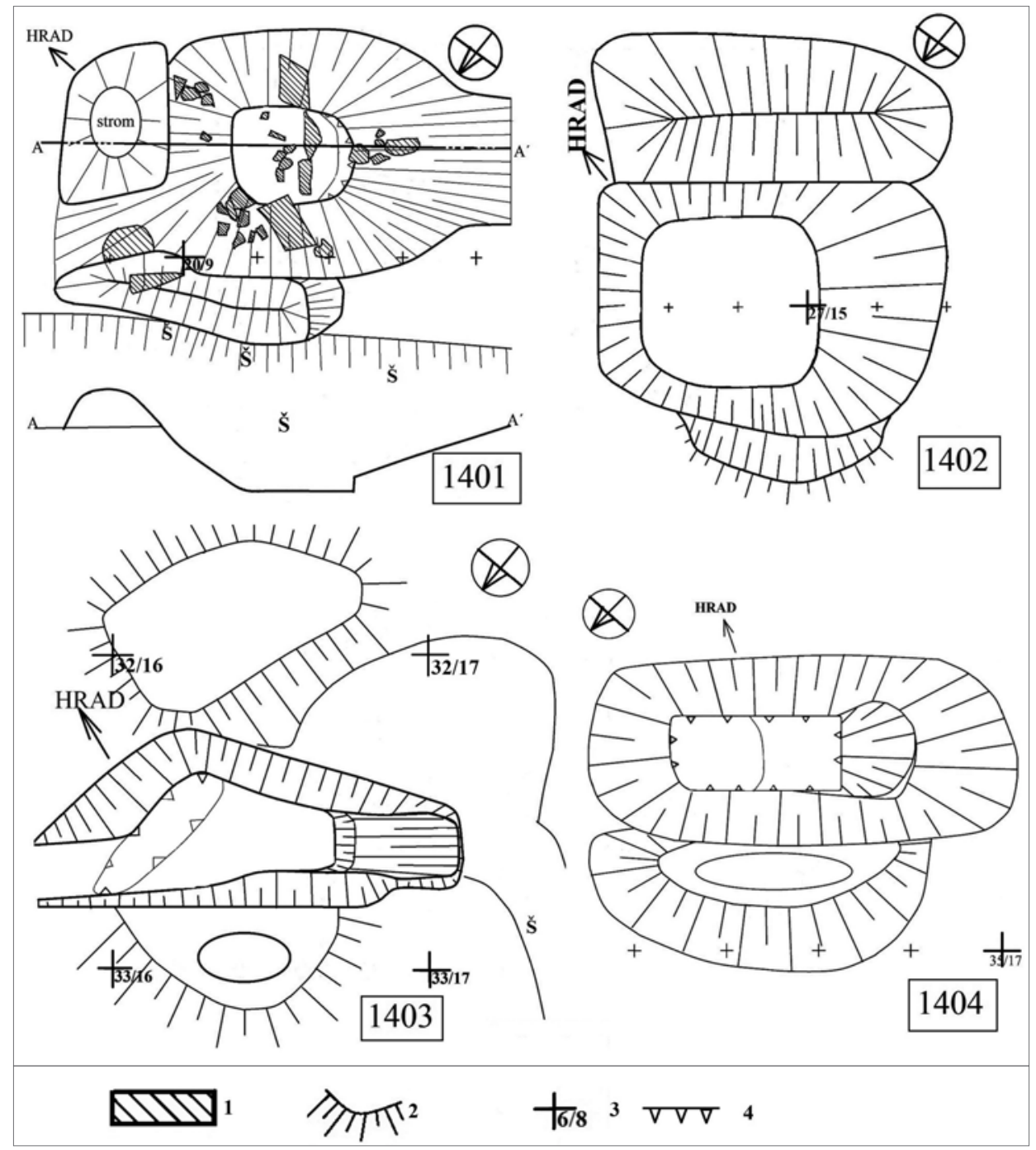

Obr. 22. Půdorysné zobrazení předsunutých zahloubených srubů 1401, 1402, 1404 a obléhacího postavení 1403.1 - kameny,

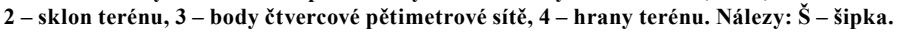

Abb. 22. Grundrissdarstellung der vorgezogenen eingetieften Blockbauten 1401, 1402, 1404 und der Belagerungsstellung

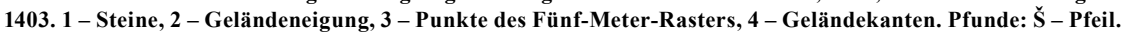

\section{Objekty 1405, 1406}

Dva sobě podobné objekty se nacházejí na opačné straně cesty proti objektu 1404 nad sebou. Jsou podélného zákopového tvaru, úzké, orientované po vrstevnici. Veškerá hlína byla tentokráte použita na valy před nimi. Jejich velikost byla $1,5 \times 0,8 \mathrm{~m}$ a jsou zahloubeny $80 \mathrm{~cm}$. Na jejich dně byla tmavá vrstva a $\mathrm{v}$ jednom prŕípadě se v ní nacházelo dno nádoby a kousky výdutě poměrně tenkostěnné černě zbarvené keramiky se slídou. 
Obléhací posty (obr. 1:1403 a 1407)

Objekt 1403 (obr. 22:1403)

Ve vzdálenosti $22 \mathrm{~m}$ severozápadně od objektu 1402 se nachází další zahloubený objekt, jehož vytvoření tentokráte přičítáme oblehatelům. Má trojúhelníkovitý půdorys orientovaný podélně po vrstevnici. Jeho maximální rozměry uvnitř jsou $3,6 \times 2,6 \mathrm{~m}$, v době existence však mohly být až 4,4 × 3,8 m. Od západu do něho klesá rampa o délce $1,7 \mathrm{~m}$, široká $1,2 \mathrm{~m}$. Proti ní na východní straně je obdobná mezera o šířce 1 až $1,3 \mathrm{~m}$ a délce $2,7 \mathrm{~m}$, kterou bylo možné zahloubený objekt opustit. Její sklon jde nejdřive mírně s kopce a následně se stáčí vzhůru ke hradu. Severní strana objektu je zarovnaná, vně dlouhá $7,2 \mathrm{~m}$, uvnitř $3,8 \mathrm{~m}$ a místy zpevněna kameny. Západní je vysoká $80 \mathrm{~cm}$ a u výjezdu splývá s terénem. Jižní strana vykazuje značný sesuv půdy. Její vnější délka činí $5 \mathrm{~m}$, uvnitř vzhledem $\mathrm{k}$ délce rampy jen 2,4 $\mathrm{m}$. Maximální zahloubení bylo ve středu $1,05 \mathrm{~m}$ a vnější rozměry dosahovaly $6,5 \times 2,8 \mathrm{~m}$.

Jihozápadně nad objektem byl terén $\mathrm{v}$ ploše $3,6 \times 2,8 \mathrm{~m}$ srovnán a před něj směrem $\mathrm{k}$ hradu byl navršen mohutný val dlouhý $3,6 \mathrm{~m}$ a široký dnes $2 \mathrm{~m}$. Byl ukončen nad jihovýchodním okrajem zahloubeného objektu, takže nebránil ve výhledu odtud na hrad. Část vytěžené hlíny byla deponována též na jižní okraj objektu.

Př́mo k nájezdové rampě se stáčí jeden ze dvou vyhloubených př́stupových zákopů, které pravoúhle odbočují z dodnes velmi dobře dochované středověké úvozové cesty a směřují prrímou trasou k tomuto místu. Šířka prŕístupového zákopu byla v místě ukončení 1,5 $\mathrm{m}$ a ústí se rozšiřovalo na $2 \mathrm{~m}$. Druhý zákop byl ukončen jen několik metrů od prvního. V závěru zákopu byla nalezena podkova, šipka a hřebíky.

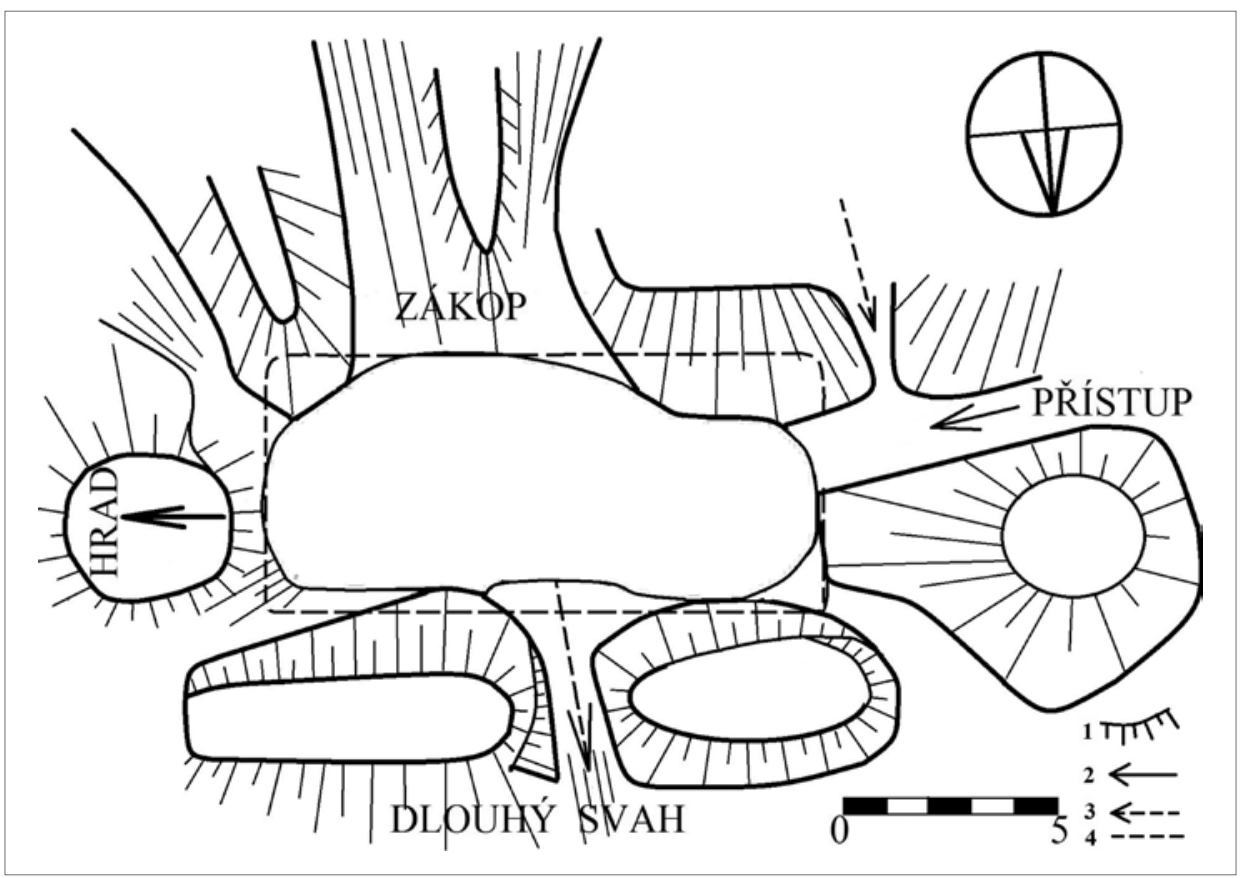

Obr. 23. Půdorysné zobrazení obléhacího postavení 1407. 1 - sklon terénu, 2 - směr přístupu do objektu a k hradu, 3 - druhotně vykopané odvodňovací kanály, 4 - původní rozsah užitného prostoru.

Abb. 23. Grundrissdarstellung der Belagerungsstellung 1407. 1 - Geländeneigung, 2 - Richtung des Zugangs zum Objekt und zur Burg, 3 - sekundär angelegte Entwässerungskanäle, 4 - ursprünglicher Umfang des Nutzraumes. 
Lze soudit, že se jedná o počáteční obléhací postavení, které bylo zřejmě osazeno dělem. I když tvar cesty ze zahloubeného objektu je optimální pro př́ípadné vytlačení děla, přikláním se k jeho umístění spíše na srovnaný povrch nad zákopem, chráněný mohutným valem.

\section{Objekt 1407 (obr. 23)}

Poslední z těchto objektů se nachází ve vzdálenosti téměř $40 \mathrm{~m}$ na jihovýchod od naposledy popsaného a $123 \mathrm{~m}$ od prvního předhradí. V obléhání hrál patrně velmi důležitou roli. Původně se totiž jednalo o obdélný objekt velikosti $11 \times 5 \mathrm{~m}$, orientovaný kratší stranou k hradu. V místě se nenachází skála ani jílovitá zemina, ale písek, ze kterého byly navršeny i valy. Objekt je zasazen do svahu klesajícího od jihu k severu, takže jako největší vyhlíží trochu nelogicky severní val, pod kterým je nejvyšší svah a který směřuje k přístupové cestě. Jeho délka je 14,5 m a v nejširším místě měří 4,1 m. Středem je druhotně prokopnut odvodňovací kanál. Svah stoupá jižním směrem, proto na severní a severozápadní straně nalézáme navršení zeminy, zatímco do jižní se objekt terasovitě zakusuje. Písková zemina se však sesunula, a proto je dnes objekt až o $2 \mathrm{~m}$ užší. Ve vzdálenosti $1,8 \mathrm{~m}$ od jihovýchodního rohu je v jižní straně $2,6 \mathrm{~m}$ široká mezera, ze které jako by vycházela cesta svahem vzhůru, místy se rozdvojuje a zase spojuje a stáčí se jihovýchodním směrem. Jak jsme zjistili, nejednalo se o cestu, ale o zákop, vyhloubený kolem jihozápadní strany hradu, tedy od jediné dobře př́stupné strany. Je možné ho sledovat v poměrně značné délce až k dnešní svážnici, kde mizí. Ve vzdálenosti 130 m se vinul kolem části hradu. Přirozenou cestou se z něho následně stal odvodňovací kanál.

Př́istup o šířce 1,2 m vedl do zadní části objektu 1407 od západu, kde se cesta jen lehce zahlubovala do terénu. Bohužel je zde přes ni vytvořen další odvodňovací kanál, takže nelze přesně identifikovat původní podobu tohoto místa. Ze starých map bylo možné zjistit, že cesta, která dnes vede poměrně daleko odtud, původně procházela těsně kolem tohoto místa.

$\mathrm{S}$ velmi zajímavou úpravou terénu se setkáváme na straně obrácené $\mathrm{k}$ hradu. Před střed této strany byl navršen kruhový val o průměru 2,6m tak, že po stranách zůstaly volné východy široké $1,7 \mathrm{~m}$ na severní a $2,45 \mathrm{~m}$ na jižní straně. Jelikož se v objektu po většinu roku drží voda, původní horizont byl zcela zničen a podlahu nebylo možné dohledat. Mohli jsme na ni usuzovat pouze na základě nálezu podkovy, kterou jsme objevili v hloubce $68 \mathrm{~cm}$ od okraje severního valu ve stř̌edu objektu. Ve valech bylo dále nalezeno pět šipek a za objektem další podkova.

Žádné další objekty, které by bylo možné ztotožnit s obránci či oblehateli, nebyly v okolí hradu nalezeny. Avšak nebyly ani nutné, nebot' ohromné množství rozměrných kamenů ležících před hradem skýtalo dostatek možností k úkrytu.

Předsunutá opevnění na hradě Skály lze považovat za jakési předchůdce samostatně bránitelných pevnůstek (Plaček 2002, 144-145), i když jejich hájitelnost byla dosti omezená. Z nálezů militarií vyplývá, že je obránci bez boje nevyklidili, okamžik ústupu však museli vyhodnotit velmi precizně. Na svazích před hradem bylo detektorem dohledáno několik šipek, ale i dalších předmětů, včetně mincí. $Z$ informací hajných je nám však známo, že „detektoráři“, kteří nás předešli, odtud odnosili značné množství různých nálezů.

\section{Severovýchodní věž (obr. 1:7)}

Severovýchodní hranolová věž se zvedá do výše $25 \mathrm{~m}$ od obvodové zdi hradu (obr. 24). Její kolmé stěny jsou přilepeny ke stejně kolmé skále. Aby se k ní člověk dostal, musí vystoupat severovýchodním prríkopem na nejvyšší místo a pak po několika skaliskách vylézt k jejímu úpatí. Poslední část je opatřena vysokými schody vytesanými do skal a úpatí srovnáno, takže kolem zdi je vytvořena plošina. V jejím středu se před zdí nachází čtvercový otvor o straně $20 \mathrm{~cm}$, $40 \mathrm{~cm}$ hluboký. Část západního nároží věže chybí a otvor se stále zvětšuje. Také z čelní strany vypadalo několik kamenů a je velmi těžké odhadnout, zda se jedná o chybějící kameny, nebo o lůžka trámů nesoucích schodiště, kterým byla věž př́istupná.

Věž je možné u jejího jižního rohu - přes $70 \mathrm{~cm}$ širokou mezeru vysoko nad zemí - obejít a dostat se do prostoru za ni. Tam jsme nalezli menší množství keramického materiálu, ale 


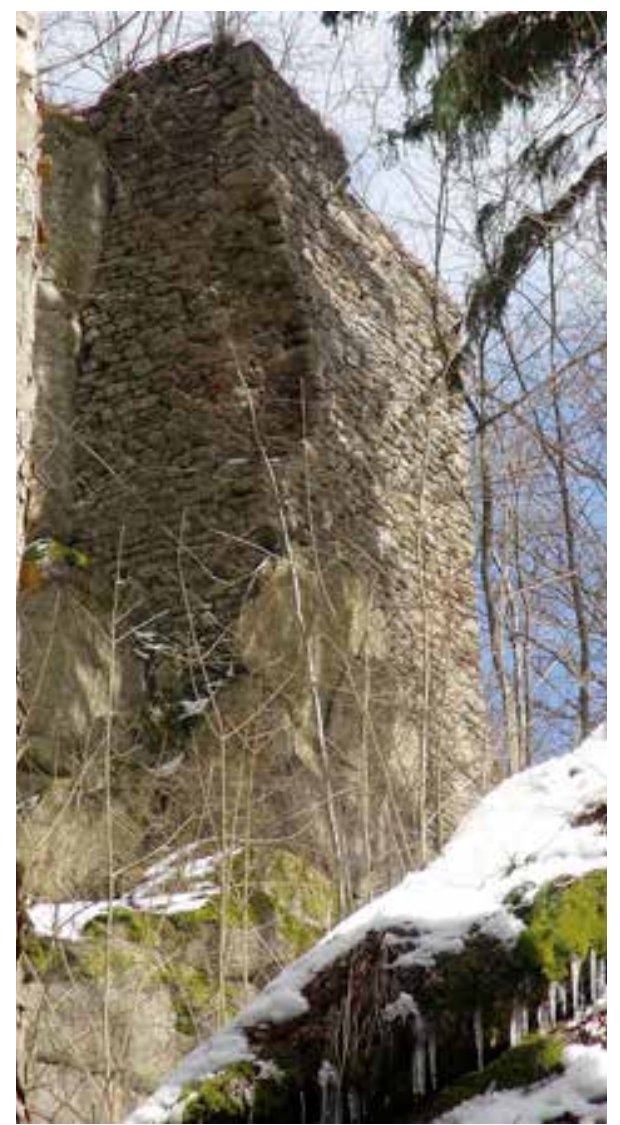

Obr. 24. Severovýchodní předsunutá hranolová věž (obr. 1:7), pohled od severozápadu.

Abb. 24. Vorgezogener nordöstlicher Prismenturm (Abb. 1:7), Blick von Nordwest. především doklad požáru věže v podobě velkých kusů zcela propáleného zdiva a malty. $\mathrm{Na}$ věž však tudy cesta nevedla.

Museli jsme si opatřit $10 \mathrm{~m}$ dlouhý vysouvací žebřík, abychom byli schopni z terasy pod věží dosáhnout jejího horního okraje. Teprve odtud bylo možné vylézt na její vrchol a zjistit její přesné parametry. K zabezpečení výstupu a k práci na vrcholu věže jsme museli použít horolezeckou výbavu a jištění.

Zjistili jsme, že vrchol skály byl obezděn ze všech čtyř stran. Ze tř́ byla věž vyzděna již od základu, od severovýchodu byl obezděn jen její vrchol. Zdivo věže bylo s vrcholem skály srovnáno do roviny, takže na vrcholu vznikla plošina o rozměrech $4,1 \times 4,9 \mathrm{~m}$. Aby ji bylo možné využít, musela být opatřena masivním dřevěným podsebitím, které shořelo. Přitom došlo $\mathrm{k}$ propálení kamenů $\mathrm{s}$ maltou na severovýchodní straně, kde přečnívaly skálu, a k jejich zrrícení. Vrchol skály je ve směru severozápad-jihovýchod obloukovitě otesán do kapkovitého tvaru o délce $2,5 \mathrm{~m}$. Z šířky $20 \mathrm{~cm}$ na severozápadní straně se postupně rozšiřuje na $1,1 \mathrm{~m}$, aby se u jihovýchodu skály opět zúžil na $60 \mathrm{~cm}$. Na severovýchodní straně vyčnívá nad dochované zdivo $30 \mathrm{~cm}$, na opačné je zdivo viditelně vytrhané $\mathrm{v}$ několika vrstvách až do hloubky $80 \mathrm{~cm}$. V jižní části jihovýchodní strany, $1 \mathrm{~m}$ pod okrajem věže, vybíhá skála šikmo vně v délce $3,5 \mathrm{~m}$ a šířce $2,4 \mathrm{~m}$. Přesně s okrajem této skály je ve zdivu $90 \mathrm{~cm}$ široká a $60 \mathrm{~cm}$ hluboká mezera, přes kterou je možné vystoupit na okraj zdiva věže, a odtud $1 \mathrm{~m}$ na její korunu. Zdá se, že zde vedla původní př́ístupová cesta navazující na schodiště, a tudy jsme na ni vystoupili i my. Na celé věži jsme nalezli pouze jediný hřebík.

I když výstup a práce na vrcholku věže byly dosti nebezpečné, zajištěni horolezeckými pomůckami jsme do sytosti mohli ocenit úžasný výhled do kraje. Vše, co se hnulo v údolí Fryšávky a daleko do polí a luk k Daňkovicím, měli pozorovatelé jako na dlani. Tato věž byla již čtvrtou zkoumanou na hradě Skály, přičemž každá z věží je zcela odlišná.

\section{Věž nad bránou}

A ještě o jedné stavbě je třeba se zmínit. Jedná se o věž na skále, vysoko nad vstupní bránou do hradu (obr. 25). Původně se zde nacházela hranolová věž, zatažena od čelní zdi jádra směrem dovnitř (obr. 1), která byla součástí již nejstarší fáze hradu. Následně byla přestavěna na věž $\mathrm{s}$ břitem. Její velikost byla $8 \times 5 \mathrm{~m}$ a měla nepravidelný tvar. Její zadní stěnu totiž tvořila rovná vnější zed' původní věže a stavitelé ji také museli přizpůsobit průběhu skal. Břit byl založen na svahu, hluboko pod úrovní dlážděné podlahy a zachovala se jen jeho spodní část. $Z$ věže bylo možné kontrolovat nejen jihozápadní plochu před hradem, ale i jihovýchodní směrem k návrší 


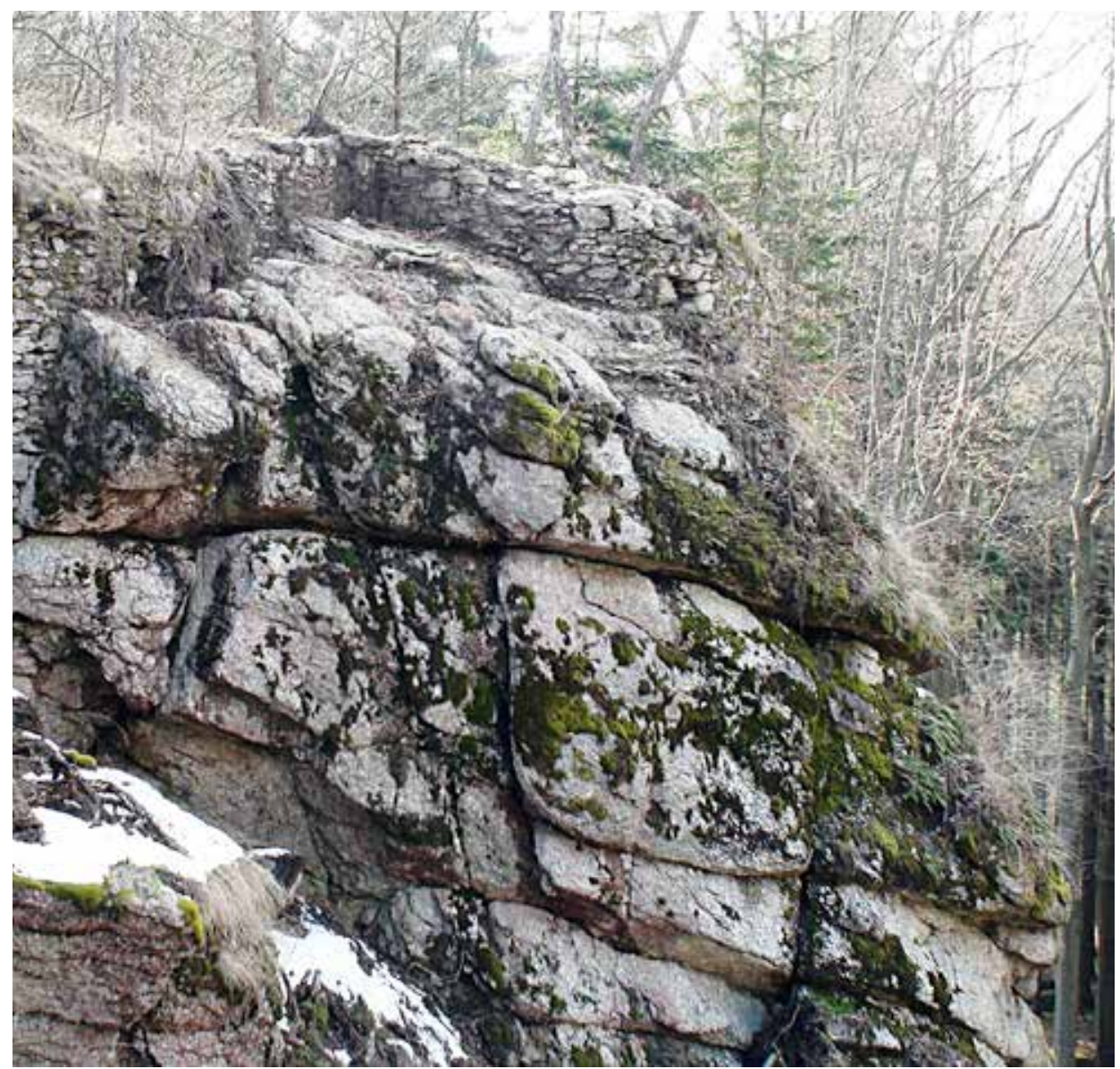

Obr. 25. Věž s břitem na skále nad bránou do hradu, pohled od severovýchodu. Abb. 25. Schnabelturm auf dem Felsen über dem Burgtor, Blick von Nordost.

a byla významným doplňkem systému obrany hradu. Svědčí o tom dělová koule zaražená ve výplni věže poté, co byla horní část břitu rozstřílena.

Upravené místo po hranolové věži využili po dobytí hradu penězokazci, kteří se tu na nějakou dobu usadili, a dokonce si postavili menší stavbu, ve které měli i malá kachlová kamna (Belcredi 2012, 583-598).

Předpokládám, že k přestavbě této věže došlo ještě za Erharta ze Skal. Pokud by totiž byla provedena až v závěru existence hradu v rámci vnějších opevňovacích prací polním vojskem, jednalo by se o jedinou přestavbu v rámci kamenného hradu.

\section{Závěr}

Archeologický výzkum hradu Skály odkryl jedinečný areál vnějšího opevnění a další objekty v jeho předpolí. Datace vzniku většiny objektů je celkem jasná. Neoddělitelnou součástí původní zástavby hradu byly obě předsunuté kamenné věže, dílna v severovýchodním př́íkopu, „vápenka“ a kovářský areál u původní cesty. 
V druhé polovině 30 . let 15 . století doznal značných změn prostor před hradem, kde před bránou vzniklo další předhradí, jemuž na rozš́iřeném sypaném valu dominovala polygonální dřevohlinitá bašta, a přebudována byla též ochrana severního nároží. V souvislosti s tím byla výrazným způsobem změněna i podoba severozápadního valu. Jako zcela nový prvek se podél přeložené přístupové cesty objevily sruby, které měly za úkol cestu střežit. Z téže doby zřejmě pochází i kovárna specializující se na barevné kovy, nacházející se v místě původního valu. Problémem vročení vzniku opevnění na návrší a datací tamních objektů jsem se již výše v textu dostatečně zabýval.

Při snaze o časové vřazení stavebních aktivit se můžeme oprrít o historii hradu. Do roku 1415 patřil významné osobě na dvoře markraběte Jošta, Erhartu ze Skal, který však měl, jak víme, dostatek problémů s dobudováním samotného hradu (Belcredi 2015). Disponoval však početnou vojenskou družinou, která mohla být umístěna právě na návrší, avšak opět by nebylo budováno opevnění směrem ke hradu, ale na opačnou stranu, nadto by se nám z jejich působení muselo zachovat množství dokladů. Následně hrad obývaly již jen lupičské skupiny, které se jistě nezabývaly stavební činností, naopak za nich hrad jen chátral. Veškeré další aktivity v tomto směru je tak možné přičíst až táborskému vojsku a zbudování některých objektů i oblehatelům.

Rozšíření vědomostí o některých dílčích problémech nám může přinést vyhodnocení nálezového materiálu, který však ještě čeká na své laboratorní zpracování.

Podobně jako u palných zbraní obranného postavení i u obléhacích máme nedostatek seriózních informací, na kterých bychom mohli stavět. Obraz obrany a průběhu obléhání až po dobytí hradu Skály před námi na základě zjištěných faktů však vyvstává až neuvěřitelně plasticky. Potvrzuje obecně popsané trendy obléhání té doby. Výjimkou jsou jen přibližovací zákopy a naprríklad i to, že k obraně sloužil též kovářský areál. Následné budování obléhacích postavení, obkličovacího zákopu, to vše probíhalo podle předem daných šablon. Lze zjistit i některá postavení a pohyb děl během obléhání až na jejich umístění na vnitřním valu, což je pro závěr obléhání též typické. Mimo účasti dělostřelectva doložené množstvím dělových koulí shledáváme v podobě nálezů šipek do kuší a olověných projektilů i účast pěchoty a dle písemných zpráv se na obléhání podílela i jízda. I když máme z předpolí hradu množství součástí koňské výbavy, její zapojení do obléhání to neprokazuje. Jak variabilní byla doba obléhání opevněného sídla, nejlépe dokládá dvojí obléhání tvrze, či spíše hradu Jana Koldy ze Žampachu v Černíkovicích. V roce 1441 ji velké vojsko se třemi děly obléhalo tři týdny, ale v roce 1449 byla mnohem menším vojskem smetena za tři dny (Wolf 2002, 41, 59 a 116). Při výzkumu jsme měli na počty nálezů mnohem větší štěstí než svého času u velmi očekávaného výzkumu E. Jánské na hradě Sionu, kde bylo nalezeno jen velmi skromné množství artefaktů (Koscelnik-Kypta-Savková 2013, 574-598). Při stejném osudu obou hradů a nesrovnatelně větším významu Sionu jsme na hradě Skály nalezli tisíce artefaktů, $\mathrm{z}$ toho značná část dokládá právě zánik tohoto hradu.

Závěry obléhání musely být provázeny značnými zmatky, nebot' je až neuvěřitelné, jak často písemné prameny uvádějí, jakému množství a jak významným osobám se podařilo z obléhaných měst a hradů uprchnout v okamžiku, kdy již bylo o jejich osudu rozhodnuto. Jestli tomu tak bylo i na Skalách, k tomu písemné prameny mlčí, a archeologické to nedoloží. Obránci Skal však měli v kapse žolíka v podobě zadní výpadové branky. Ovšem vytáhnout ho mohli pouze $\mathrm{v}$ př́ípadě, že by o něm oblehatelé nevěděli.

Kresby a fotografie 2 až 21 - autor.

\section{Literatura}

BELCREDI, L., 1990: Čepička - opevnění nad klášterem Porta coeli v Tišnově-Předklášteří, ČMMZ LXXV, 99-122.

- 2006: Bystřec. O založení, životě a zániku středověké vsi: archeologický výzkum zaniklé středověké vsi na Drahanské vrchovině 1975-2005. Brno. 
- 2010: Hrad Skály aneb o prstenu paní Elišky. Historie a archeologický výzkum hradu. Brno.

-2011: Stavební podoba jádra hradu Skály. In: Hrad jako technický problém. Technologie a formy výstavby středověkých opevněných sídel (Měřínský, Z., ed.), 6-38. Brno.

- 2012: Penězokazecká dílna na hradě Skály. In: Mezi raným a vrcholným středověkem. Pavlu Kouřilovi k šedesátým narozeninám přátelé, kolegové a žáci, 583-598. Brno.

- 2015: Stavební vývoj a dispozice předhradí hradu Skály. Př́íspěvek k poznání předhradí menších hradů - Bauliche Entwicklung und Anlage der Vorburg von Burg Skály. Ein Beitrag zum Verständnis der Vorburgen kleinerer Burgen, AH 40, 553-582.

DURDÍK, T., 1991: Česká hradní architektura doby husitské, ČSPS 99, č. 3, 151-164.

- 1992: Abriss der Entwicklung der böhmischen Burgen im 15. und am Anfang des 16. Jahrhunderts A 15. század és a 16. század eleje cseh várépítészete fejlödésének vázlata, CaBe 2/1990, 321-339.

- 1996: Abriss der Entwicklung der böhmischen Artillerieburgfortifikationen des 15. und des beginnenden 16. Jahrhunderts - Outline of the Development of the Bohemian Artillery Castle Fortifications of the 15th and Early 16th Centuries, Castella maris baltici II, 35-46.

- 1999: Ilustrovaná encyklopedie českých hradů. Praha.

- 2003: K otázce užití palných zbraní při obraně středověkých fortifikací, Hláska XIV, 16.

- 2011: Entstehung eines rein militärischen Machtstützpunktes Fallbaispiel Hartenštejn im Böhmen. In: Die Burg im 15. Jahrhundert. im Auftrag der Deutschen Burgenvereinigung herausgegeben von Joachim Zeune (Hofrichter, H., ed.), 114-124. Braubach.

- 2011a: Husitské hrady. In: Víšek, Z.-Hrabánková, B., Slánské rozhovory 2010. Česká husitská reformace, 12-16. Slaný.

GABRIEL, F., 2006: Teoretické aspekty studia hradních staveb. Ústí nad Labem.

KOSCELNÍK, P.-KYPTA, J.-SAVKOVÁ, J., 2013: Dobývání hradu Siónu roku 1437. Povrchový průzkum palebných postavení oblehatelů - The capture of Sión Castle in 1437. A surface survey of the besieging army's firing positions, AR LXV, 574-598.

KYPTA, J.-RICHTEROVÁ, J., 2002: K metodice studia pozdně středověkých zemních fortifikací, Hláska XIII, 54-56.

MĚ̌̌́́NSKÝ, Z., 1972: Nález loštického poháru typu IA z hradu Skály - Štarkov (okr. Žd’ár nad Sázavou), ČMMZ LVII, 237-241.

PLAČEK, M., 2002: Externí fortifikace moravských hradů - Die externe Fortifikation der mährischen Burgen, AH 27, 139-154.

- 2007: Ilustrovaná encyklopedie moravských hradů, hrádků a tvrzí. Praha.

PLAČEK, M.-MĚŘÍNSKÝ, Z., 1992: Die Burgen Mährens im Spätmittelalter - Morvaország várai a késö-középkorban, $\mathrm{CaBe} 2 / 1990,276-295$.

SÝKORA, M., 2013: Hrady doby husitské. Diplomová práce, FF UK.

ŠIMŮNEK, R., 2010: Hrad jako symbol v myšlení české středověké šlechty - The Castle as a Symbol in the Consciousness of Czech Medieval Aristocracy, ČČH 108, 185-219.

VARHANÍK, J., 2002: Obrana středověkého hradu palnými zbraněmi - Die Verteidigung der mittelalterlichen Burg mit den Feuerwaffen, AH 27, 125-136.

- 2003: Ještě k palným zbraním př̌i obraně středověkých fortifikací, Hláska XIV, 32-33.

VAVŘINEC Z BŘEZOVÉ, 1979: Husitská kronika. Píseň o vítězství u Domažlic. Red. M. Bláhová. Praha. WAGNER, E.-DROBNÁ, Z.-DURDÍK, J., 1956: Kroje, zbroj a zbraně doby předhusitské a husitské. Praha. WOLF, V., 2002: Jan Kolda ze Žampachu. Hradec Králové - Trutnov.

\section{Zusammenfassung}

\section{Die Außenbefestigung von Burg Skály und weitere Objekte im Burgvorfeld}

Die in Tschechien durchgeführten archäologischen Grabungen konzentrieren sich vor allem auf die Teile von Burgen mit Steinarchitektur. Die Forscher verzichteten auf Erdfortifikationen im Außenbereich, die somit bislang unbekannt bleiben, und wenn sich jemand mit ihnen beschäftigt, wird von ihnen infolge der schlichtweg raren Geländegrabungen eher theoretisch gesprochen, was dann auf Geländeprospektionen oder ggf. auf dem Studium verschiedener Aufnahmen basiert. Ebensowenig wurde bisher dem Problem der Bedeutung von Kanonenfeuer, sowohl was Verteidigung, als auch die Belagerung von Burgen anbelangt, genügend Aufmerksamkeit entgegengebracht. Dabei stehen diese beiden Sachen in einem engen Zusammenhang. 
Vorgezogene Befestigungen sind in vielen Fällen deswegen entstanden, weil es unmöglich war, früher gebaute Burgen mit Kanonen zu bestücken, mit einer Kriegstechnik, die in Böhmen zwar früher bereits bekannt war, sie aber erst in den Hussitenkriegen allgemeine Verbreitung fand.

Somit ist die Grabung auf Burg Skály eine der ersten dieser Art. Die Burg befindet sich, wie üblich, auf der Spitze eines Hügels, jedoch ungefähr $80 \mathrm{~m}$ unter ihm. Drei Seiten der Burg werden durch Felsblöcke gebildet, lediglich die vierte wird von einer Mauer abgeschlossen. Das machte sie ganz und gar einzigartig, und zur Zeit ihres Entstehens in den siebziger Jahren des 14. Jahrhunderts war sie praktisch uneinnehmbar. Bis zum Jahr 1415 war sie Residenzburg der Herren von Skály. Dann wurde sie von der Räuberbande ihres Verwandten Erhart Puška von Kunstadt bewohnt, und während der Hussitenzeit von einer kleinen prohussitisch gesinnten Gruppe. Nach der Schlacht bei Lipan (1434) traf eine zahlreiche Gruppe von Taboriten dort ein, welche die Burg bis zu ihrem Ende im Jahr 1440 in Beschlag hielt. Albrechts Annalenschreiber schreibt, dass es bis zu 500 gewesen sein sollen und dass sie von dort aus großen Schaden anrichteten. Nachvollziehbarerweise nehmen wir an, dass die Außenbefestigung von Burg Skály gerade aus diesem Zeitraum stammt.

Die Grabung auf dem Burgvorfeld ist die Fortsetzung der Freilegung des Burgkerns und der Vorburg, was bereits veröffentlicht wurde. Die Südost- und Nordostseite der Burg wurden von Felsen und Steilhängen ausreichend geschützt, sodass dort keine größeren Arbeiten nötig waren. Lediglich an der Südseite befand sich am Felsen ein Halbkreisturm (Abb. 1:8 und Abb. 17), und am höchsten Punkt des nordöstlichen Grabens war am Felsen ein Prismenturm angeheftet (Abb. 1:7 und Abb. 24). Die Spitze von Felsen und Mauerwerk war eben, sodass sich darauf eine Hurde befunden haben muss. Ihre Überreste von einem Brand haben wir vor allem auf der Nordostseite hinter dem Turm vorgefunden.

Die Südwestseite war mit einem Doppelgraben und einem Wall versehen, von denen sich der innere hinter dem Tor bis zur Außenmauer hinzog, und der äußere ursprünglich um die Nordwestseite bis zu den Felsen im Nordosten weiterführte (Abb. 1). Die Befestigung der ersten Vorburg (Abb. 2) ging von der Erkenntnis aus, dass im Burgareal keine Kanonen aufgestellt werden können und im Burgvorfeld die bestmöglichsten Verteidigungselemente genutzt werden müssen. Ein weiterer Grund war das Bestreben, den Zugangsweg so zu verlegen, damit ein möglichst langer Abschnitt von ihm kontrolliert werden kann. Alle Aufmerksamkeit konzentrierte sich somit auf die Befestigung der beiden Stützpunkte an der Ecke der Außenmauerfassade.

Auf dem verbreiterten von der Westecke der Außenmauer in den Graben auslaufenden Wall entstand vor dem Burgtor ein befestigtes Areal mit einer Größe von $22 \times 25 \mathrm{~m}$ (Abb. 1:3 und Abb. 2). Der Verkehrsweg wurde von der Südwestseite, wo er nach Überwinden des Außenwalls fast in einer Geraden von der Burg weiterführte, auf die Nordwestseite verlegt und mit einem Tor versehen (Abb. 2:543). Von Nordosten wurde er von einer auf dem halbkreisförmig aufgeschütteten Wall und eine Fläche von $10 \times 12,5 \mathrm{~m}$ einnehmenden polygonalen sechsseitigen Bastei aus Holz-Lehm bewacht, von der wir sagen können, dass sie einen völlig einzigartigen Beleg für die erhaltene Fortifikation der Burg darstellt (Abb. 3). Sie wurde mit der Technik zweier parallel verlaufender Balkenwände errichtet, die $50 \mathrm{~cm}$ voneinander entfernt stehen. Die Balken der Wände waren verschränkt, sodass jeder an vier Punkten der gegenüberliegenden Wände fixiert war (Abb. 3-8). Zwischen die Balkenwände wurde Lehm-Sand-Erde eingestampft. Die Fundamentbalken der Innenwände ruhten auf dem Boden, die äußeren wurden bis zu $70 \mathrm{~cm}$ hangabwärts eingelegt. Die Decke des Blockbaus bildete eine $30 \mathrm{~cm}$ starke Lehmbewurfschicht, die, nachdem der Blockbau abgebrannt war, einstürzte und uns eine Fülle von Funden bewahrte. Der Blockbau war mit einem kleinen Ofen zur Unterhaltung des Feuers für Schusswaffen versehen (Abb. 3:311 und Abb. 9). Die andere Seite der Einfahrt wurde von einer mit dem gleichen Ofentyp versehenen Kanonengeschützstellung mit einer kippbaren Schießscharte bewacht (Abb. 2:540). Unter anderem sind dort fünf unbenutzte Kanonenkugeln liegengeblieben, deren Oberfläche jedoch nicht geglättet war. Die erste Vorburg war von einer Palisade umgeben, die aus zwischen Pfählen befestigten, waagerechten Balken bestand. Über eine Länge von $17 \mathrm{~m}$ folgte sie dem Wall und verlief nach der Verankerung in einer ausladenden Grube, wo sich in Richtung Felsen 
am Fußgängertor offenbar auch ein Eckblockbau befand (Abb. 2:555). Dass die Befestigung über einen längeren Zeitraum einer Belagerung standhielt wird durch die hohe Zahl an Funden angedeutet, zu denen auch Kanonenkugeln, Pfeile und Bleiprojektile zählen, in den Hof war sogar auch eine Bombardenkugel gefallen (Abb. 2:RB).

Die zweite Grundidee zur Neuerrichtung einer Außenbefestigung war die Sicherung der verwundbaren Nordecke (Abb. 1:4). Sie hat einen fast runden Grundriss, einen Durchmesser von $9 \mathrm{~m}$ und einer ebenen Oberfläche, die offenbar auch für die Aufstellung von Kanonen hergerichtet wurde, da die ursprüngliche Befestigung mit der aus trocken übereinandergestapelten Steinen bestehenden Außenwand eingetieft war (Abb. 11:625). Um den Umfang zeichnen sich Halbkreisbögen ab, die offenbar von der Außenfassade stammen (Abb. 13), und die hinlänglich ebene Fläche vor ihr war bis zu den Kreisen abgebrannt. Dort haben Schützenkörbe mit Lehm stehen können. Die Befestigung wird von Nordwesten her durch einen bis zu $8 \mathrm{~m}$ breiten halbkreisförmigen Graben geschützt, jedoch wurde der Wall vor dem Graben wegen der Sicht auf den Hang beseitigt. In einer Entfernung von $13 \mathrm{~m}$ wurde quer zu ihm ein ebenso großer, interessanter $10 \mathrm{~m}$ langer und 2 bis $2,5 \mathrm{~m}$ breiter und gleich hoher Wall nicht standardmäßig hangabwärts aufgeschüttet, der einen direkten Angriff auf die Befestigung verhindern sollte (Abb. 1: Quadrate 12-13/-4 und -5). Das Objekt wurde aus einem Lehm-Sand-Material aufgeschüttet. Abgesehen davon war über den ganzen Hang eine riesige Menge großer Steinblöcke verteilt, die den Zugang zur Burg erschweren sollten. Auch haben wir dort Belege für zähe Kämpfe vorgefunden.

Der südwestliche Wall vor der Burg hat beträchtliche Veränderungen erlitten. Der äußere Wall endete an der Stelle, wo der ursprüngliche Zugangsweg durch ihn hindurchführte, und dadurch dass dieser verlegt wurde, entstand im Wall eine $27 \mathrm{~m}$ lange Lücke (Abb. 1). Eine weitere befand sich gegenüber der Nordseite der Lehm-Sand-Bastei, wo der Wall nicht nur in einer Breite von $10 \mathrm{~m}$ entfernt worden war, sondern durch ihn auch ein $1,2 \mathrm{~m}$ breiter Kanal durchbrochen wurde, offenbar wiederum wegen einer freien Sicht von der Bastei auf den Hang, eventuell auch um die Angreifer direkt gegen die Hauptverteidiger zu leiten. Die letzte, bereits erwähnte Niedrigerlegung des Walls erfolgte vor der Befestigung der Nordecke. Bei der Belagerung der Burg wurde nach der Zuschüttung des Kanals der mittlere Teil des Walls bis zu einer Breite von $14 \mathrm{~m}$ auseinandergescharrt, damit man dort eine Bombarde verankern konnte. Ein weiterer Belagerungsposten entstand auf einem viel kleineren Raum auf der gegenüberliegenden Seite des zugeschütteten Kanals. Der Graben hatte nämlich während der Hussitenzeit seine Bedeutung eingebüßt, da es wichtiger war, den Feind stets im Auge zu behalten. Als Verteidigungselement ist er jedoch nicht verschwunden.

In einer Entfernung von $20 \mathrm{~m}$ vor dem Tor haben wir auch eine Esse mit der Stelle für den Blasebalg in einer Gesamtgröße von $1 \times 3,7 \mathrm{~m}$ gefunden (Abb. 1:6). Den Funden nach diente sie zur Bearbeitung von Buntmetallen. Im nordöstlichen Graben befand sich eine $4 \times 4 \mathrm{~m}$ große Werkstatt, in der Gegenstände aus Kupferblech hergestellt wurden, was durch hunderte von Kupferschnipseln belegt wird (Abb. 1:5). Um die Burg herum fand man auch eine Reihe von Müllkippen aus verschiedenen Epochen.

In einer Entfernung von ungefähr $100 \mathrm{~m}$ befindet sich oberhalb der Burg eine langgestreckte Anhöhe mit den Abmessungen von $50 \times 20 \mathrm{~m}$, die sich von den Felsen im Norden nach Süden hinzog (Abb. 1:10 und Abb. 16). In einem relativ steilen Anstieg auf der der Burg abgewandten Seite wurde ein Doppelgraben und ein Wall angelegt, der bloße $20 \mathrm{~m}$ vom Südwall der Burg entfernt beginnt. Fünfzehn Meter höher haben wir zwischen den Felsen die erhalten gebliebene Mauerflucht eines $90 \mathrm{~cm}$ breiten und 1,3 m langen Tor gefunden, das zu einem $4 \times 3,5 \mathrm{~m}$ großen Kalkofen führt (Abb. 1:9 und Abb. 14). Der Raum wurde von einem im Südosten liegenden hohen Felsen abgeschlossen, auf dessen Spitze ein Halbkreisturm gesetzt wurde, unter dem wir eine $1,7 \mathrm{~m}$ hohe und 2,3 $\mathrm{m}$ breite Schicht einer Kalkmasse entdeckt haben, die auch schwere Brocken reinen Kalks enthält (Abb. 15). Unter der Kalkschicht entdeckte man einen unglaublich ebenen, grau- bis violettrot gefärbten Fußboden. Er bestand aus einer zusammenhängenden Schicht kleiner Steinblöcke, die dicht nebeneinander gelegt worden waren, und zwar waren diese von einer solchen Härte, dass die Hacke von ihnen lediglich mit hellem Klang abprallte. Im 
Hinblick auf die fehlende Steinarchitektur kann nicht ausgeschlossen werden, dass es sich nur um eine Kalkdeponie gehandelt hat. Der letzte mit Kalk gebaute Bau wurde lange vor Untergang der Burg errichtet, da man auf ihr nach 1415 bereits nur noch Holzbauten begegnet. Das bedeutete keinen Rückzug von der Pracht der Steinarchitektur, sondern im Hinblick auf die Erfahrungen verwendete man in der Hussitenzeit häufiger Holz-Stein-Lehm-Aufschüttungen mit Holzbauten.

Auf der eingeebneten Anhöhe begegnen wir mehreren Objekten (Abb. 16). Außer einem Turm (Abb. 16:1 und Abb. 17) handelt es sich um einen eingetieften Blockbau, der einen kleinen Ofen und eine Fülle an Funden enthielt und dessen Funktion darin bestand, den Osthang zu bewachen, wo die Gräben und Wälle nicht fertiggestellt worden waren (16:4). Ferner gab es dort zwei leichte Holzbauten mit Feuerstelle und eine nicht fertiggestellte Zisterne (Abb. 16:2, 6 und 7). Der bedeutendste Bau war eine mächtige, 7,7 m lange Holz-Lehm-Wand, die bis zu einer Höhe von 1,2 m erhalten geblieben ist (Abb. 16:8 und Abb. 18). In der Fortsetzung der quer stehenden Felsen schloss sie die Anhöhe von Süden her ab und unterbrach den ursprünglichen Zugangsweg (Abb. 16:12) auf dem der Kalk befördert wurde (Abb. 16:11). Die Holz-Lehm-Wand erreichte das Höhenniveau der Anhöhe an der Stelle, an welcher der Blockbau errichtet wurde. Zusammen mit dem Rand der Anhöhe brach er ab und rutschte unter den hohen Hang, wo er eine mächtige Schicht abgebrannten Lehmbewurfs und interessante Funde hinterließ. Auch dort wurde eine kleine Kanonenkugel gefunden. Außer Keramik und Knochen aus dem eingetieften Objekt gab es auf der ganzen Anhöhe sonst keine Funde, was sehr verblüffend ist. Wir haben dort nur Armbrustpfeile gefunden. Es stellt sich die Frage, in welcher Phase die mächtigen Gräben und Wälle auf der Nordwestseite der Anhöhe in Richtung Burg errichtet worden waren. Durch den entfernteren nordöstlichen Hang verläuft nur ein Graben und ein nicht fertiggestellter Wall. Im Hinblick auf Analogien nehme ich an, dass dort die ursprüngliche Burg errichtet wurde bevor es zur Entscheidung kam, sie zwischen den Felsen aufzubauen. Ihre Errichtung durch die Armee der Taboriten oder durch Belagerer ist im Hinblick auf das völlige Fehlen von Funden und der Lage der Wälle nur wenig wahrscheinlich.

In einer Entfernung von 10 bis $25 \mathrm{~m}$ vom ursprünglichen Eingang zum zweiten Wall befand sich ein Schmiedeareal mit einer Fülle von Schlacke, Zunder und weiteren Belegen für eine Schmiede, was von Überresten mehrerer Bauten und eingetiefter Objekte begleitet wurde (Abb. 1:12 und Abb. 19). Zu ihrer Zuschüttung war es noch während der Existenz der Burg gekommen, worauf Belege einer Schlacht und die Oberfläche der Objekte hindeuten. Die Verfüllungen enthielten viele interessante Funde. Von den Essen und Feuerstellen sind lediglich eine eingetiefte runde Feuerstelle und ansonsten einige Brandstätten erhalten geblieben.

Die letzten Objekte im Burgvorfeld stellen Blockbauten dar, die den Zugangsweg bewachten. Das größte Objekt befand sich bloße $20 \mathrm{~m}$ vom Tor zur ersten Vorburg entfernt (Abb. 1:13 und Abb. 20). Es wurde zwischen zwei großen Steinen auf einer unscheinbaren, jedoch umso wichtigeren Anhöhe in Richtung Zugangsweg errichtet, der in einer Entfernung von nur $5 \mathrm{~m}$ an ihm vorbei verlief. In ihm fanden sich eine Fülle von Knochen, Keramik und auch Metallgegenständen, die für ein intensives Leben an diesem Ort sprechen, ferner gab es noch Militariafunde einschließlich einer Kanonenkugel. Als einer der wenigen Objekte fiel es keinem Brand zum Opfer. Darauf deutet die Schicht unverbrannten Lehmbewurfs hin, die auf seinen Plattenfußboden gefallen war. Nach Einnahme dieses Ortes richteten die Belagerer dort eine der wichtigsten Geschützstellungen ein, von wo aus sie den Verteidigungsblockbau und das Tor beschossen. Auf dem Hang lag zwischen Blockbau und dem Weg ein völlig allein stehender dreieckförmiger Stein (Abb. 21), dessen Funktion sich uns entzieht, ebenso wie der eines ähnlichen, im Schmiedeareal gefundenen Exemplars.

Unterhalb der Burg befand sich im unteren Teil des Hanges ein Geländebruch, unter dem der Zugangsweg entlang führte. An seiner Grenze wurden zwei eingetiefte Blockbauten errichtet (Abb. 1:1401, 1402 und Abb. 22), von denen man eine kommende Person noch früher sehen konnte, bevor diese die Burg sah. Weitere drei Objekte (Abb. 1:1404-1406 und Abb. 22:1404) befanden sich am Eingang von einem Hohlweg am Hang vor der Burg. Nicht weit entfernt von ihnen befinden sich auch zwei Objekte, die den Belagerern zugeschrieben werden. Das kleinere 
von ihnen (Abb. 1:1403 und Abb. 22:1403) befindet sich am Eingang von zwei Annäherungsgräben, die vom Hauptweg aus ausgehoben wurden. Es hat einen dreieckförmigen, eingetieften Teil und einen oberirdischen, mit einem Wall versehenen Teil. Ich vermute, dass es sich um eine der ersten Belagerungsstellungen gehandelt hat. Das zweite und größere Objekt (Abb. 1:1407 und Abb. 23) befand sich fast $50 \mathrm{~m}$ südlicher. Es hatte eine rechteckige Form mit einer ursprünglichen Größe des Innenraums von $11 \times 5 \mathrm{~m}$. Da sich das Objekt in den Südhang hineinfrisst, wurde in nördliche Richtung ein großer Wall aufgeschüttet, der heute von einer Entwässerungsrinne durchstoßen wird. Von der südöstlichen Ecke ging von ihm ein Graben aus, der einen Teil der Burgvorderseite umschloss. Vor der Mitte der der Burg zugewandten Seite war ein offenbar ursprünglich kreisförmiger Wall mit einem Durchmesser von 2,6 m so aufgeschüttet worden, dass an den Seiten freie Eingänge blieben, die 1,7 m und 2,45 m breit waren und sofortige Ausfallangriffe sowie einen Kanonenbeschuss auf vorgelagerte Stellungen ermöglichten.

Durch die archäologische Grabung des Vorfeldes der Burg Skály wurde ein einzigartiges Areal einer Außenbefestigung aus den dreißiger Jahren des 15. Jahrhunderts freigelegt, dessen Dominanten aus einer in das Areal der ersten Vorburg eingefügten Holz-Lehm-Bastei, aus Produktionsobjekten einschließlich eines Kalkofens oder einer Deponie und aus vorgezogenen und Belagerungsstellungen bestehen, die über ihre Geschichte und ihren Untergang Auskunft geben.

Zeichnungen und Fotos 2 bis 21 - vom Verfasser.

PhDr. Ludvík Belcredi, Pohankova 8, 62800 Brno, belcredil@seznam.cz 
